MICHELY JABALA MAMEDE VOGEL

\title{
A noção de estrutura lingüística e de processo de estruturação e sua influência no conceito e na elaboração de linguagens documentárias
}

Dissertação de Mestrado

São Paulo

2007 


\title{
A noção de estrutura lingüística e de processo de estruturação e sua influência no conceito e na elaboração de linguagens documentárias
}

\begin{abstract}
Dissertação apresentada à Escola de Comunicações e Artes da Universidade de São Paulo, como parte dos requisitos para a obtenção do título de Mestre em Ciência da Informação, Área de Concentração: Cultura e Informação.
\end{abstract}

Orientadora: Prof ${ }^{a}$. Dr ${ }^{\text {a }}$. Marilda Lopes Ginez de Lara

São Paulo

2007 


\section{Autorizo:}

[X] divulgação do texto completo em bases de dados especializadas.

[X] reprodução total ou parcial, por processos fotocopiadores, exclusivamente para fins acadêmicos e científicos.

Assinatura:

Data: $07 / 05 / 2007$

Vogel, Michely Jabala Mamede

A noção de estrutura lingüística e de processo de estruturação e sua influência no conceito e na elaboração de linguagens documentárias / Michely Jabala Mamede Vogel. São Paulo : M . J. M. Vogel, 2007.

124 p. : il.

Dissertação (mestrado) - Escola de Comunicações e Artes/USP, 2007.

Bibliografia

O exemplar 1 não pode ser emprestado

Linguagens Documentárias

Estruturalismo

Teses

$\mathrm{t}$ 


\section{Termos de Aprovação}

Nome do Autor:

Título da Dissertação/Tese:

Presidente da Banca: Prof. Dr.

Banca Examinadora:

Prof. Dr. Instituição:

Prof. Dr. Instituição:

Prof. Dr. Instituição:

Aprovada em:

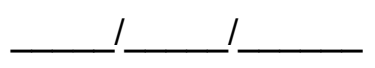


Existe entre cada um de nós e qualquer outra pessoa o muro de uma língua estranha.

(M. Proust. Em busca do tempo perdido, v.3, p.468). 
Dedico esta dissertação a meus pais - meu porto seguro sempre! 


\section{Agradecimentos}

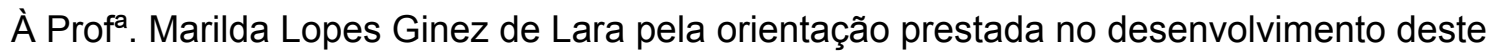
trabalho, e também por sua paciência e rigor ao longo destes anos;

Às Prof ${ }^{\text {as }}$. Nair Yumiko Kobashi e Anna Maria Marques Cintra, pela preciosas orientações no exame de qualificação;

À Profa. Maria de Fátima G. M. Tálamo, pelas dicas valiosas, dadas até nos momentos mais inusitados;

A todos os colegas e amigos pelo apoio e incentivo constantes;

A meus pais, pelo constante estímulo, apoio e força durante todos estes momentos. Sem vocês esta dissertação não teria acontecido;

Enfim, a todos aqueles que me ajudaram, de uma forma ou outra, a realizar uma travessia como esta,

Muito Obrigada!!! 


\section{Sumário}

\section{RESUMO}

\section{ABSTRACT}

LISTA DE QUADROS

LISTA DE FIGURAS

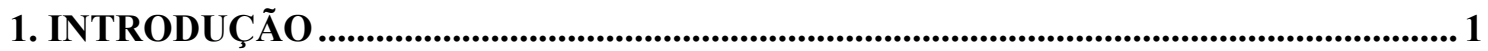

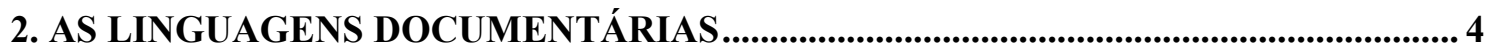

2.1. O CAMPO DE ESTUDOS DA LINGUAGEM DOCUMENTÁRIA ............................................. 4

2.2. EVOLUÇÃO DO CONCEITO DE LINGUAGEM DOCUMENTÁRIA ........................................... 8

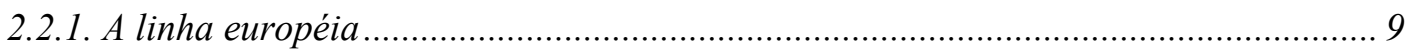

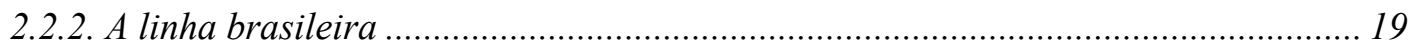

2.3. QUADRO COMPARATIVO SOBRE OS CONCEITOS DE LINGUAGEM DOCUMENTÁRIA ......... 33

3. A LINGÜÍSTICA ESTRUTURALISTA E A NOÇÃO DE ESTRUTURA ....................... 35

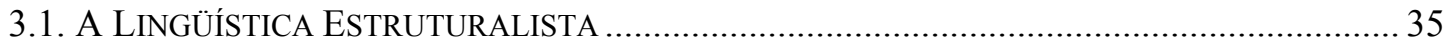

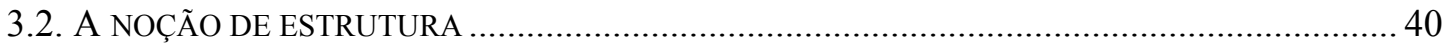

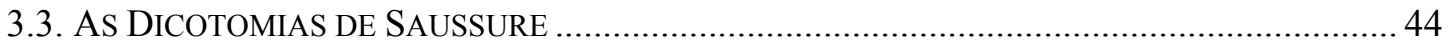

3.4. A INTRODUÇÃO DO SUJEITO NA TEORIA ESTRUTURAL .................................................. 50

3.5. APROPRIAÇÃO DA LINGÜÍSTICA PELA DOCUMENTAÇÃO................................................. 55

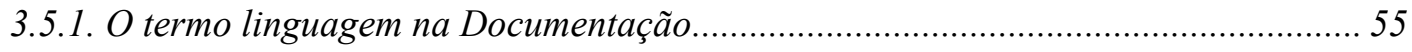

3.5.2. Linguagem Natural versus Linguagem Documentária ........................................ 62

4. A TERMINOLOGIA E AS LINGUAGENS DOCUMENTÁRIAS ................................. 73

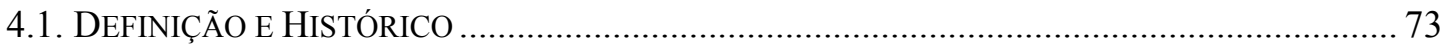

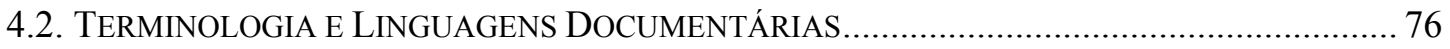

5. ANÁLISE DE LINGUAGENS DOCUMENTÁRIAS.....................................................8 


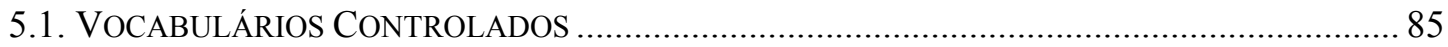

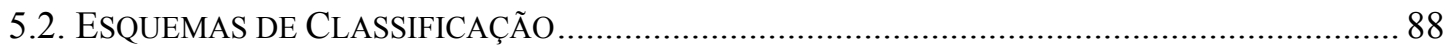

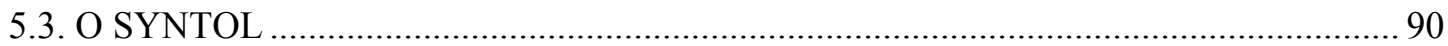

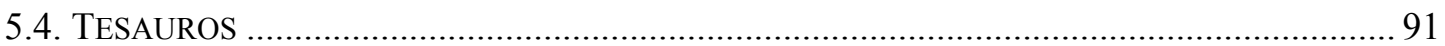

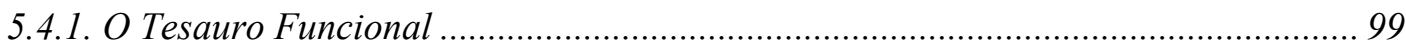

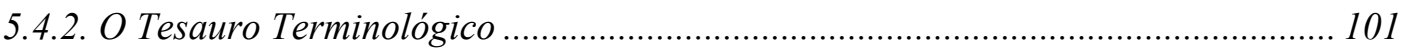

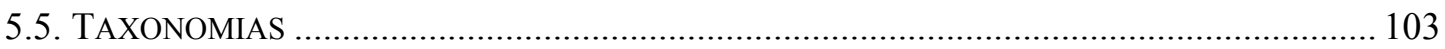

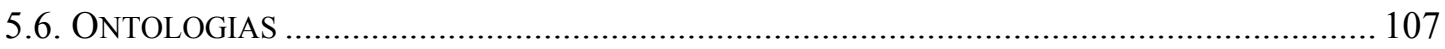

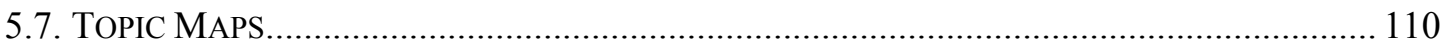

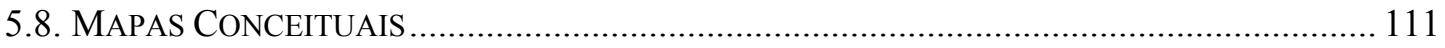

5.9. A LingUAGEM EPISTEMOGRÁFICA DE GARCÍA GUTIÉRREZ .................................... 111

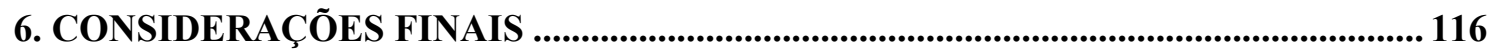

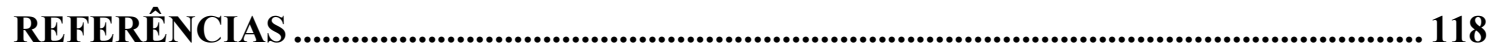


VOGEL, Michely Jabala Mamede. A noção de estrutura lingüística e de processo de estruturação e sua influência no conceito e na elaboração de linguagens documentárias. São Paulo, 2007. 127p. Dissertação (Mestrado em Ciência da Informação) - Escola de Comunicações e Artes, Universidade de São Paulo.

\section{Resumo:}

Estudo apoiado em revisão bibliográfica sobre a evolução das Linguagens Documentárias tendo como foco a apropriação da noção de estrutura da Lingüística Estrutural pela Documentação. A revisão compreende parte das pesquisas desenvolvidas na Europa, notadamente por Jean-Claude Gardin, García Gutiérrez e Hutchins, e no Brasil, pelo Grupo Temma. A partir da análise das reflexões apresentadas, propõe-se um quadro das principais características das Linguagens Documentárias. Para referendar a observação concreta das Linguagens Documentárias, explora-se o conceito de estrutura lingüística e das propostas iniciais de seu desenvolvimento, realizando um breve apanhado sobre a apropriação da Lingüística pela Documentação. Discute-se o significado do termo linguagem na Documentação e estabelece-se o cotejamento entre as características da Linguagem Documentária, da linguagem artificial e da linguagem natural. Em seguida, a partir da constatação de que a Terminologia opera com a noção de estrutura e de estruturação, procura-se verificar como se concretiza esse apoio para efeito de organização sistêmica das Linguagens Documentárias e, finalmente, a partir dos conceitos e reflexões reunidas anteriormente, realiza-se um exercício para verificar se, e como, os conceitos lingüísticos são integrados às Linguagens Documentárias e instrumentos semelhantes. Conclui-se que todos os instrumentos utilizam, de um modo ou outro, a noção de estrutura, variando em rigor como a integram, mas nem tanto a de estruturação. A atualização das estruturas inicialmente propostas, via estruturação e reestruturação contínuas, é que se apresenta como problema.

\section{Palavras-chave:}

Linguagem Documentária ; Lingüística Estrutural ; Noção de Estrutura; Processo de estruturação ; Terminologia 
VOGEL, Michely Jabala Mamede. The notion of linguistic structure and of structuration process and the influence of both on the concept and on the development of documentary languages. São Paulo, 2007. 127p. Dissertação (Mestrado em Ciência da Informação) Escola de Comunicações e Artes, Universidade de São Paulo.

\section{Abstract:}

It is a bibliographic review study on the evolution of Documentary Languages that focuses on the appropriation of the structure notion of the Structural Linguistics by the Documentation. The review contains part of the developed researches in Europe, notably by Jean-Claude Gardin, García Gutiérrez e Hutchins, e in Brazil, by Grupo Temma. Bystander analysis of the presented reflections, it is proposed a framework of the main characteristics of the Documentary Languages. To support the concrete observation of the Documentary Languages, it is explored the concept of linguistic structure and of the initial ideas of its development, making a brief survey on the appropriation of Linguistics by Documentation. It is discussed the meaning of the term 'language' in the Documentation and it is established the differences and similarities of the characteristics of the Documentary Language, the artificial languages and the natural language. Subsequently, bystander the statement that Terminology operates with the notion of structure and of making structure, it searches to verify how this support can be concrete to the systemic organization of the Documentary Languages, and finally, bystander concepts and reflections reunited previously, it is done an exercise to verify if, and how, the linguistics concepts are integrated to the Documentary Languages and similar tools. It is concluded that all the tools use, in a hand or another, the structure notion, varying the form and the rigor of how it is applied. But they do not apply as well the notion of making structure. The actualization of the structures initially proposed, by means of making continuous structure an re-structure, still presents as a problem.

\section{Key-words:}

Documentary Language ; Structural Linguistics ; Structure Notion ; Structure Process ; Terminology. 


\section{Lista de Quadros}

QUADRO 1 - LINHA EUROPÉIA: DENOMINAÇÕES PARA AS LINGUAGENS DOCUMENTÁRIAS .........................18

QUADRO 2 - LINHA EUROPÉIA: FunÇÕES DAS LINGUAGENS DOCUMENTÁRIAS ...........................................19

QuAdRo 3 - LINHA BRASILEIRA: DENOMINAÇõES DAS LINGUAGENS DOCUMENTÁRIAS .............................32

QUADRO 4 - LINHA BRASILEIRA: FUNÇÕES DAS LINGUAGENS DOCUMENTÁRIAS ........................................32

QUADRO 5 - ESTRUTURA, CARACTERÍSTICAS E FUNÇÕES DAS LINGUAGENS DOCUMENTÁRIAS...................33

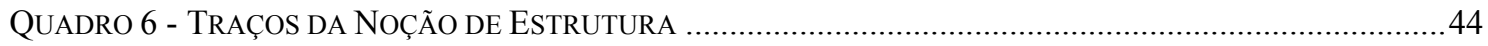

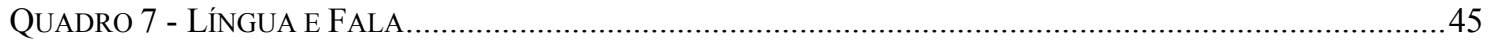

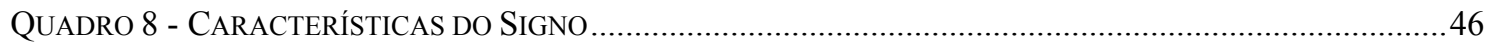

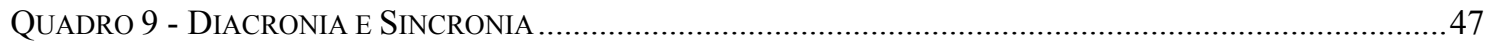

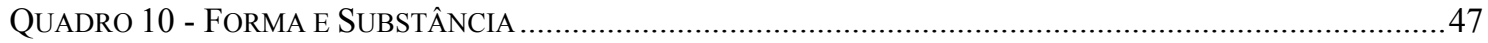

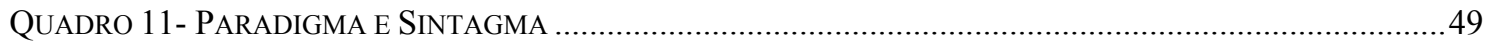

QUADRO 12 - COMPARAÇÃO ENTRE LINGUAGEM NATURAL E LINGUAGEM DOCUMENTÁRIA .....................64

QUADRO 13 - DiFERENÇAS ENTRE Linguagem NATURAL, ARTIFICIAL E DOCUMENTÁRIA ........................66

QUADRO 14 - COMPARAÇÃO ENTRE LiNGUAGEM NATURAL E LINGUAGEM DOCUMENTÁRIA. .....................67

QUADRO 15 - CATEGORIAS DO ESTRUTURALISMO NAS LINGUAGENS DOCUMENTÁRIAS .............................69

QUADRO 16 - SIGNO NAS LINGUAGENS NATURAL E DOCUMENTÁRIA.........................................................70

QUADRO 17 - COMPARAÇÃO ENTRE LINGUAGEM DOCUMENTÁRIA E TERMINOLOGIA..................................83

QUADRO 18 - CARACTERÍSTICAS GERAIS DOS VOCABULÁRIOS CONTROLADOS.............................................87 


\section{Lista de Figuras}

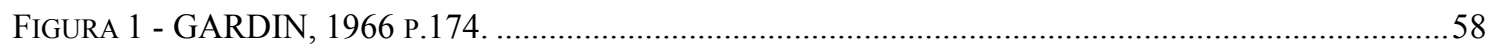

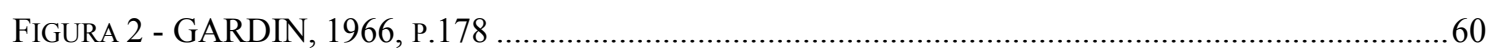

FIGURA 3 - ESQUEMA DE CLASSIFICAÇÃO DE NEGÓCIOS ........................................................................100

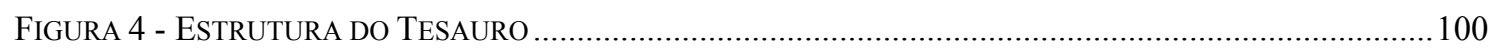




\section{Introdução}

A Ciência da Informação preocupa-se com a organização e recuperação da informação e, para isso, propõe metodologias e instrumentos, como os vocabulários controlados que, com o tempo, se sofisticaram na forma de Linguagens Documentárias para otimizar a indexação e a busca da informação. O conceito de Linguagem Documentária foi se refinando com o passar dos anos. $E$ conseqüentemente, a metodologia de construção de Linguagens Documentárias foi também sendo aprimorada. Da simples identificação de ocorrência e freqüência dos termos na literatura, passou-se a propor o arranjo organizacional dos termos que tem, na noção de estrutura lingüística uma de suas referências principais.

Estudar a influência do conceito de estrutura na organização de Linguagens Documentárias, e por conseqüência, a própria organização da informação, permite que se sistematize aquilo que a área já elaborou. Além disso, a reflexão sobre o tema permite subsidiar a atualização desse conjunto de conhecimentos, importantes para influir na otimização dos instrumentos de acesso à informação, sua circulação e comunicação. Só deste modo é possível avaliar o estado da arte das metodologias de elaboração de Linguagens Documentárias, verificando seus avanços e problemas. Neste trabalho pretendemos observar como a noção de estrutura, originalmente proposta por Saussure, como seu desenvolvimento, se faz presente nas Linguagens Documentárias. Pretendemos verificar se e como ela é observada nas diferentes contribuições da área de Ciência da Informação ao longo do tempo.

O tema de nossa pesquisa se justifica pela oportunidade de refletir sobre as formas de organização utilizadas nas Linguagens Documentárias. A área de Ciência da Informação carece de discussões sobre a elaboração e aplicação desses instrumentos, e a compreensão das metodologias, conceitos e teorias que influenciam 
sua construção, bem como os seus desenvolvimentos, é fundamental para o seu contínuo aperfeiçoamento.

O objetivo principal desta pesquisa é o de observar a organização das Linguagens Documentárias para identificar suas semelhanças, diferenças, bem como a maior ou menor proximidade ao uso do conceito de estrutura lingüística, tal como definida por Saussure. Pretendemos verificar como o conceito de estrutura foi - e vem sendo utilizado ao longo do tempo e em que medida ele é efetivamente apropriado pela Ciência da Informação, e principalmente, quais as vantagens que sua aplicação na elaboração de Linguagens Documentárias traz para o tratamento de informações.

A metodologia a ser utilizada parte da discussão da noção de estrutura, tal como proposta inicialmente pela Lingüística de Saussure, considerando seus desenvolvimentos contemporâneos. O encaminhamento da discussão prevê a exploração da noção de estrutura nas Linguagens Documentárias, a partir da pesquisa na literatura sobre Documentação, Lingüística Estruturalista e seus desenvolvimentos, e Terminologia.

No presente capítulo, introduzimos o tema elucidando os objetivos do trabalho, a motivação e a metodologia a ser utilizada. No segundo capítulo introduziremos o tema das Linguagens Documentárias, localizando-o na área da Lingüística Documentária, sub-campo que se preocupa com os fundamentos teóricos e metodológicos da Linguagem Documentária.

Procuraremos traçar a evolução do conceito de Linguagem Documentária a partir da linha européia (França, principalmente) e da linha brasileira (Grupo Temma), examinando, ao menos em parte, a literatura específica produzida por representantes 
da vertente originada com Jean-Claude GARDIN, a fim de propor um quadro com as principais características.

Em seguida, no terceiro capítulo, abordaremos o estruturalismo lingüístico e a noção de estrutura, referindo-nos às dicotomias propostas por Saussure, em seu Curso de Lingüística Geral. Introduziremos brevemente a atualização da idéia de estrutura com a introdução do sujeito nos processos de organização da estrutura lingüística. Discutiremos também os principais trabalhos da Documentação que seguem as propostas do estruturalismo lingüístico, procurando identificar, nas Linguagens Documentárias, suas influências e modos de aplicação. É neste capítulo que procuraremos verificar o quanto as Linguagens Documentárias integram os conceitos de língua e de sua estruturação, sistematizando as principais características que a diferenciam da linguagem natural, no que concerne à Documentação.

No quarto capítulo procuraremos mostrar as relações da Lingüística Documentária com a Terminologia, visando verificar como as contribuições da literatura terminológica podem beneficiar o desenvolvimento das Linguagens Documentárias.

No quinto capítulo, apresentaremos as principais Linguagens Documentárias, analisando nelas a presença dos conceitos estruturais e terminológicos, bem como ressaltando seus contextos de uso.

Nas considerações finais, faremos a sistematização das contribuições analisadas. 


\section{As Linguagens Documentárias}

\subsection{O campo de estudos da Linguagem Documentária}

O campo que estuda a Linguagem Documentária tem sido progressivamente delineado. Observa-se que, inicialmente, não se distingue especificamente uma área exclusiva que trate desses instrumentos, remetendo-se seu estudo à Documentação de modo genérico. Com GARDIN, as Linguagens Documentárias são incluídas no campo da Análise Documentária e é com GARCÍA GUTIÉRREZ que começa a tomar forma um sub-campo particular denominado Lingüística Documentária. Como é natural numa área em formação ou transformação, há flutuação de denominações, não se podendo identificar claramente quando as distinções efetivamente passam a ganhar corpo. Para efeito deste trabalho, procuraremos percorrer os textos da literatura sobre o tema com a finalidade de confirmar esse desenvolvimento, utilizando a terminologia encontrada nos diversos tempos. Neste percurso deveremos identificar, também, as características atribuídas ao termo 'Linguagem Documentária'.

Pela afirmação de GARCÍA GUTIÉRREZ, em 1996, verifica-se que, dentro da Ciência da Informação, a área que produz as Linguagens Documentárias é a Documentação, que se preocupa com o "conjunto de procedimentos que se ocupam da organização e circulação do conhecimento e da cultura de massas" (GARCÍA GUTIÉRREZ, 1996, p.6). A Documentação também é referida por CINTRA e outras em 1994 (CINTRA e outras, 1994), como na edição de 2002 e 2005 (CINTRA e outras, 2002; 2005). Confirma-se o que foi dito quando as autoras afirmam que ela tem sido "responsável pela triagem, organização e conservação da informação, bem como pela viabilização a seu acesso" (CINTRA e outras, 2002, p.21). A Documentação se encarregaria de dar conta das necessidades de informação que variam de domínio para domínio, o que 
tornaria necessário um trabalho sistemático, começando pela coleta de dados, operações de controle e registro do material, descrição bibliográfica, até a descrição de conteúdo (idem, p.24-25). Para as autoras, a Documentação conta com instrumentos conhecidos como Linguagens Documentárias ou LDs (CINTRA e outros, 2002, p.33), lembrando que:

\begin{abstract}
"nas décadas de 1950 e 1960, com o crescimento do conhecimento científico e tecnológico, houve dificuldades para armazenar e recuperar informações. A solução foi encontrada com uma mudança do enfoque e da conceituação da recuperação da informação. Com efeito, foi abandonada a perspectiva preferencial de recuperação bibliográfica e normalização classificatória e descritiva, buscando-se a construção de linguagens próprias".
\end{abstract}

Embora sem uma delimitação clara do campo, reconhece-se uma área de estudos (ou sub-campo) que se volta especificamente às Linguagens Documentárias. De acordo com DODEBEI (2002, p.12), a partir dos anos quarenta as Linguagens Documentárias:
"passam a ser objeto de estudo, não só dos bibliotecários, como de lingüistas e outros profissionais preocupados com a representação de conteúdos informativos para fins de recuperação e disseminação da informação, tradução automática, análise de conteúdo, análises literárias, semióticas e lingüísticas, realizadas manualmente ou de forma automática".

Num primeiro momento, as Linguagens Documentárias integravam o processo de Análise Documentária. A Análise Documentária, termo criado por GARDIN (1973, p.144-6), parte de três pressupostos principais:

1. Análise Documentária é a extração de sentidos de texto, o que implica em algo que é "tirado" do texto e designado por um símbolo - que não está necessariamente no texto, Esse processo gera uma metalinguagem. Por 
isso, GARDIN (1973, p.144) afirma que "Análise Documentária impõe o uso de uma (meta-) linguagem artificial (...) diferente da linguagem natural”.

2. Independentemente do campo ou dos objetivos da metalinguagem, os procedimentos para seu desenvolvimento são similares, em três aspectos:

a. Nos procedimentos usados para definir a unidade de análise;

b. No levantamento das relações analíticas oferecendo uma organização semântica à metalinguagem;

c. No fornecimento de relações sintáticas, dando uma estrutura lógica à metalinguagem.

3. Para fins práticos se faz uma distinção entre relações analíticas (ou semânticas) e sintáticas (ou lógicas):

a. Assim, é preciso apreender o que são essas relações;

b. É preciso relacionar as duas relações;

c. É preciso tornar a conversão ente linguagem natural e a metalinguagem fácil e simples.

Ou seja, para GARDIN (1973, p.146), a Análise Documentária envolveria o desenvolvimento de metalinguagens que precisam ser elaboradas de forma independente, por campos separados, mas que exibem similaridades estruturais.

Posteriormente, percebeu-se que apesar da Análise Documentária fazer uso de Linguagens Documentárias, o desenvolvimento destas não é um procedimento da 
Análise Documentária propriamente dita. De acordo com GARCÍA GUTIÉRREZ, a "Documentação apresenta dois corpus que se imbricam com a lingüística: a Análise Documentária e a Lingüística Documentária" (1990, p.24-25), mas que não formam uma mesma área.

Verifica-se, portanto, que a Análise Documentária utiliza as Linguagens Documentárias, contudo não é responsável por sua elaboração. De fato, reconhece-se o papel das Linguagens Documentárias nos procedimentos de Análise Documentária. Uma Linguagem Documentária responde "pela análise de tratamento da informação com o objetivo de recuperá-la e disseminá-la" (LARA, 1993b, p.4).

A partir desse reconhecimento, GARCÍA GUTIÉRREZ (1990) propôs a criação de um sub-campo da Documentação que denominou Lingüística Documentária, que compreenderia o estudo dos meios de representação da informação, com foco nas linguagens de processamento e produção para fins de circulação do conteúdo informacional.

Como afirmam LARA e TÁLAMO (2006),

"O termo Lingüística Documentária foi inicialmente utilizado por GARCÍA GUTIÉRREZ em 1990 (GARCÍA GUTIÉRREZ, 1990) para sugerir uma disciplina que, partindo do reconhecimento de que os problemas relacionados à informação são problemas de linguagem, busca seus fundamentos nas ciências da linguagem de um modo geral. Recorre, portanto, à lingüística, à semântica, à gramática aplicada à gestão da informação, como aos campos afins, como a análise do discurso, a análise do conteúdo e, de modo geral, as ciências cognitivas (GARCÍA GUTIÉRREZ, 1998)".

Verifica-se que as autoras adotam o termo ao afirmarem que a Lingüística Documentária é que responde pelo desenvolvimento de parâmetros para a elaboração 
das Linguagens Documentárias, apoiando-se para isso, na Lingüística Estrutural, na Semiótica, na Terminologia e na Lógica Formal (TÁLAMO e LARA, 2006, p.207). O artigo em questão - "O campo da Lingüística Documentária" - permite confirmar a aceitação do termo proposto por GARCÍA GUTIÉRREZ, como a delimitação do subcampo:

\footnotetext{
"O reconhecimento explícito que o tratamento e a disseminação da informação não consistem na formulação de verbalizações, mas na elaboração de seqüências organizadas em linguagem construída, exige de forma crescente a composição de um sub-domínio na Ciência da Informação para agregar os problemas decorrentes dos processos simbólicos do tratamento e da recuperação da informação, pesquisá-los e buscar soluções que minimizem a distância entre os estoques e o uso informação" (idem).
}

Feita essa introdução à delimitação do sub-campo de estudos hoje reconhecido, focalizaremos especificamente o conceito de Linguagem Documentária, já que é a partir dela que o sub-campo se organiza.

\subsection{Evolução do Conceito de Linguagem Documentária}

A fim de entender o conceito da Linguagem Documentária, veremos sua evolução enquanto conceito para, então, apresentaremos um quadro com suas características e funções.

O que hoje conhecemos por Linguagem Documentária recebeu diversas denominações no decorrer do tempo, de acordo com entendimento do conceito e de suas características. Neste trabalho, restringiremo-nos à exploração de algumas contribuições da vertente européia, principalmente a linha francesa e seus desenvolvimentos, na Espanha, por GARCÍA GUTIÉRREZ, e as considerações de HUTCHINS (Inglaterra); posteriormente, trataremos da vertente brasileira que teve 
nessa vertente sua origem. Reconhecemos, no entanto, que as diferentes vertentes atribuem diferentes denominações a esse instrumento de comutação, conforme os aspectos colocados em destaque.

Para dar uma idéia do problema, citamos DODEBEI (2002, p.40), que se reporta à dissertação de Wanderley (1973) que apresenta um levantamento das denominações que as Linguagens Documentárias receberam ao longo do tempo. Elas foram chamadas de 'linguagens de indexação', por Melton, de 'linguagens descritoras', por Vickery, de 'codificações documentárias', por Grolier, de 'linguagens de informação', por Soergel, de 'vocabulários controlados', por Lancaster, de 'lista de assuntos autorizados', por Montgomery, e também de 'linguagens de recuperação da informação' ou 'linguagens de descrição de informação' (WANDERLEY, 1973, p.173 citado por DODEBEI, 2002, p.40).

As denominações acima põem em destaque diferentes traços: os instrumentos para realizar o processo (Melton), a função de descrição (Vickery), a artificialização (Grolier, Lancaster, Montgomery), o propósito (Soergel) e a função de recuperação. Mas é a denominação da linha européia que enfatiza os aspecto da linguagem nessas ferramentas.

\subsubsection{A linha européia}

A linha européia é representada por autores como GARDIN, COYAUD, CHAUMIER, GARCÍA GUTIÉRREZ e HUTCHINS. GARCÍA GUTIÉRREZ ressalta que: "Usava-se o termo 'linguagem' para denominar instrumentos classificadores desprovidos de essência lingüística. Isso até o aparecimento das linguagens combinatórias que 
inspiraram, despertaram um maior interesse pela lingüística"1 (GARCÍA GUTIÉRREZ, 1990, p.76).

Jean-Claude GARDIN é um dos primeiros autores a reconhecer que a atividade de representação documentária se desenvolve no universo da linguagem. Como já apontamos, ele é o responsável pela introdução do termo "Análise Documentária" na literatura da Documentação, e tornou-se uma das principais referências na pesquisa sobre representação documentária. Uma de suas grandes contribuições foi utilizar os parâmetros lingüísticos para propor a organização de Linguagens Documentárias, (LARA, 1999, p.52-4), o que mostra seu pioneirismo.

GARDIN, em um artigo de 1966, apresenta a idéia do que viria a ser conhecido como Linguagem Documentária. O termo inicialmente usado por ele foi Léxico Documentário, que o autor define como "uma lista de termos, organizados ou não, quer servem à indexação documentária", ou ainda, como um inventário das correspondências entre os termos dessas listas e as palavras ou frases em linguagem natural que eles representam (GARDIN, 1966, p.175).

No mesmo ano, COYAUD (1966) usa em seu livro o termo Linguagem Documentária, que define como "um sistema de signos" que permite a comunicação entre usuário e documentalista quando o primeiro busca um documento ou referência (1966, p.5). Para ele:

"Uma linguagem documentária é uma ferramenta de comunicação mediata, que serve para a comunicação entre seres humanos e outros humanos autores de documentos. Dito de outra forma, a

\footnotetext{
${ }^{1}$ Todas as traduções dos textos em idiomas estrangeiros constituem tradução livre da autora.
} 
linguagem documentária é aquela que o homem emprega para acessar certos documentos localizados entre outros documentos, em um certo local, diversamente definido" (idem, p.16).

Pode-se afirmar que COYAUD foi um dos primeiros autores da área de Documentação a associar a Linguagem Documentária à comunicação.

Para GARDIN a metalinguagem utilizada para representação constitui

“(...) o conjunto dos símbolos através dos quais serão expressas as equivalências e as diferenciações introduzidas na fraseologia de um corpus LN dado, para que apareçam as aproximações desejadas entre as palavras, grupos de palavras, preposições, etc" (GARDIN², 1970, p.633, citado por LARA, 1993b, p.16).

Alguns anos mais tarde, em artigo sobre Análise Documentária e Lingüística, GARDIN utiliza o termo 'Linguagem Informacional', que seria usado para as classificações e Linguagens de Indexação, cobrindo tanto listas de termos de índice ou descritores (GARDIN, 1973 p.141). No mesmo texto, o autor também volta a se referir ao termo metalinguagem, que agora define como:

\begin{abstract}
"sistema de símbolos usado para expressar conteúdos, (...) tanto externos à linguagem-objeto na qual o documento sob análise foi escrito, como com a intenção de facilitar a manipulação destes documentos em várias formas e para vários objetivos (ex.: recuperação, classificação, individualização etc. de informação científica, estudos folclóricos, exegeses, etc)" (idem, p.144).
\end{abstract}

${ }^{2}$ GARDIN, J.C. Procédures d'analyse sémantique dans les sciences humaines. In: POUILLON, J.; MARANDA, P. (orgs.). Échanges et communications: mélanges offerts à Claude LéviStrauss à l'occasion de son 60ème anniversaire (Tiraje à part). Paris: Mounton, 1970, p.628657. 
CROSS e outros (1968, p.26), em pesquisa coordenada por GARDIN, já adotam o termo Linguagem Documentária em seu trabalho. Os autores afirmam que Linguagem Documentária é "todo conjunto de termos, e em alguns casos de procedimentos sintáticos convencionais, utilizados para representar um certo conteúdo de documentos científicos, para fins de classificação ou de pesquisa retrospectiva de informação".

Os autores acima acreditam que usamos as Linguagens Documentárias, pois precisamos 'condensar' o conteúdo de textos científicos, a fim de acelerar a consulta, ao preço admitido de uma certa perda de informação; precisamos normalizar a expressão desse conteúdo para que noções ou temas análogos sejam sempre designados pelos mesmos termos ou grupos de termos. Os termos desse vocabulário, segundo os autores, precisam ser organizados em classes semânticas (CROSS e outros, 1968, p.27-38). Assim, os autores (idem, p.29-30) continuam:

"A pesquisa automatizada de informações na literatura científica impõe como evidência a elaboração e o emprego de um sistema de correspondências entre os elementos lingüísticos próprios dessa literatura (palavras, construções gramaticais, frases, etc) e as informações que exprimem - um sistema de correspondência, diriam os lingüistas, entre "significantes" e "significados". A linguagem documentária não é nada mais que esse sistema, desenvolvido diversamente, contudo, de forma que se compõe somente de um léxico e/ou de uma sintaxe convencionais, limpos de certas impropriedades de vocabulários e gramáticas naturais, ou que compreende também as tabelas e regras de correspondência de uma linguagem natural versus uma linguagem documentária dada".

Verifica-se, acima, a idéia de sistema que se desenvolve à parte da linguagem natural, mas que apresenta relações com os termos dela oriundos. Nota-se, também, que os 
autores corroboram a idéia de que a linguagem natural é 'impura', contrariamente ao que deveria acontecer com a linguagem científica.

Um pouco mais tarde, GARDIN ainda trabalha com o conceito de metalinguagem, que define agora como um sistema simbólico que faz a mediação entre textos e sua representação (GARDIN ${ }^{3}$, 1974, citado por KOBASHI, 1989, p.48). A menção à metalinguagem, neste texto, tem a finalidade de fazer ressaltar o caráter simbólico do vocabulário organizado para gerar as representações de textos.

Nota-se que o termo 'metalinguagem' não é utilizado para substituir o termo Linguagem Documentária, mas para ressaltar uma de suas características.

No mesmo ano, CHAUMIER (1974) trabalha com as linguagens documentais, classificando-as em dois grupos: linguagens combinatórias (léxicos) e linguagens de estrutura hierárquica (classificações). Para o autor:

\begin{abstract}
"As linguagens documentais clássicas, quer sejam de estrutura hierárquica ou de estrutura combinatória, são linguagens que têm um grande desenvolvimento lexical e podem possuir uma rede de relações semânticas. Mas não possuem relações sintáticas, são linguagens sem gramática. A representação de um documento faz-se unicamente por meio de uma seqüência de palavras, sempre tomadas numa única forma" (CHAUMIER, 1974, p.74).
\end{abstract}

No entanto, o mesmo autor ressalta a superioridade das linguagens de estrutura combinatória: "as linguagens de estrutura combinatória possuem grande maleabilidade e riqueza devido à multiplicidade das noções que podem ser expressas por combinação dos termos do vocabulário utilizado num dado sistema" (CHAUMIER,

${ }^{3}$ GARDIN, J.C. Les analyses de discours. Neuchâtel, Delachaux et Niestlé, 1974. 
1969, p.63). O aspecto a salientar aqui é a importância conferida aos mecanismos de articulação da Linguagem Documentária, à semelhança do que ocorre na linguagem natural. São esses mecanismos que fazem uma linguagem no seu sentido mais verdadeiro.

CHAUMIER $^{4}$ (1978, p.17, citado por TÁLAMO, 2001, p.145) destaca, em texto posterior, que "embora a noção de linguagem documentária seja tão antiga quanto os primeiros sistemas documentários, sua utilização nem sempre foi acompanhada do rigor necessário".

HUTCHINS, autor inglês que também emprega o termo, considera que as Linguagens Documentárias são os meios de comunicação em sistemas de informação (HUTCHINS, 1975, p.3) entre documentos e leitores potenciais (idem, p.9). O autor considera que linguagens como os sistemas de classificação decimal são Linguagens Classificatórias, enquanto que linguagens como os tesauros são Linguagens de Indexação. Em nota de rodapé, ele reafirma que o termo Linguagem Documentária é mais abrangente (idem, p.9). Ao fazê-lo, HUTCHINS demonstra a necessidade de caracterizar os instrumentos que apresentam um espectro mais amplo de relações entre seus termos como sendo mais característicos de uma 'linguagem' em seu sentido efetivo. Para o autor, "as propriedades estruturais características das Linguagens Documentárias são largamente determinadas pelos seus requisitos funcionais particulares" (idem, p.11).

Outros teóricos falam, também, de Linguagem Documentária. Em 1987, os espanhóis GARCÍA GUTIÉRREZ e LUCAS FERNÁNDEZ utilizam o termo Linguagem

${ }^{4}$ CHAUMIER, J. Les langages documentaires. Paris, EME: 1978. 
Documentária ${ }^{5}$, definindo-as como linguagens que "oferecem normas para indexar univocamente os documentos e as demandas estabelecidas pelos usuários com o fim de produzir míninos índices de ruído e silêncio documentário" (GARCÍA GUTIÉRREZ e LUCAS FERNÁNDEZ, 1987, p.67). Os autores também enfatizam suas funções de organização ou classificação dos dados de um campo científico, técnico ou especializado e a unificação dos critérios de análise da informação na fase de entrada do sistema, com os da recuperação da informação, na fase da saída.

Para GARCÍA GUTIÉRREZ, a Linguagem Documentária é um sistema híbrido "com estrutura e funções próximas (...) aos sistemas naturais" (GARCÍA GUTIÉRREZ, 1990, p.33). O autor continua (idem, p.35):

“(...) a linguagem documentária, segundo o método estruturalista, seria um sistema organizado de elementos dotados de significação determinada pelas relações que mantêm entre estas baseadas na oposição. Neste caso, tanto a estrutura como seus elementos são artificiais e o principal condicionante do significado é o uso".

Pode-se observar que GARCÍA GUTIÉRREZ ressalta a noção estrutural que subjaz à Linguagem Documentária, uma vez que afirma a significação como resultado de relações opcionais, noção fundante do conceito de estrutura como se verá em capítulo posterior.

No entanto, o autor não vê a Linguagem Documentária como uma metalinguagem, pois:

\footnotetext{
${ }^{5}$ No espanhol, utiliza-se "Lenguaje Documental", mas convencionou-se traduzir o termo para o português como "Linguagem Documentária", tal como os franceses. As traduções portuguesas adotam o termo 'linguagem documental'.
} 
"As Ids flutuam no nível pragmático e não no teórico e sua aproximação crescente à estrutura da linguagem natural elimina a acepção metalingüística usada para denominar listas de meros elementos simbólicos como efetivamente são muitas classificações" (idem, p.28).

DUCROT e TODOROV, em 1973, e DUCROT e SCHAEFFER, em 1995, seguem a definição de Hjelmslev, e propõem a seguinte definição de 'metalíngua' em seus dicionários: "Quando o plano do conteúdo é, por si mesmo, uma linguagem, encontramo-nos perante uma metalíngua (exemplo: a língua técnica utilizada para a descrição das línguas naturais)" (DUCROT e TODOROV, 1973, p.41; DUCROT e SCHAEFFER, 1995, p.47). Para LARA, esse não é exatamente o caso da Linguagem Documentária, pois como lembra a autora (1993b, p.128), "ela não é um instrumento para "descrever" a linguagem-objeto, mas para representá-la documentariamente". Para a autora, as "LDs são desnaturalizadas porque são construídas buscando a normalização. Metalinguagem e linguagem desnaturalizadas são essencialmente diferentes" (idem). Porém, uma vez que uma Linguagem Documentária possa servir como um instrumento com a função, ainda que secundária, de reconhecer a significação de uma dada área através sua linguagem, aí sim se poderia falar em Linguagem Documentária como metalinguagem. CUNHA e KOBASHI (1991, p.48) dizem que "Em Documentação, "representar" é traduzir um conteúdo por meio de uma metalinguagem", e teríamos entre os produtos dessa representação as Linguagens Documentárias.

GARCÍA GUTIÉRREZ pensa a Linguagem Documentária como um instrumento comutador e referencial do sistema (1990, p.79), cuja função é estritamente informativa (idem, p.70), e que intervém como mediadora nos processos de Análise Documentária (idem, p.71). 
No dicionário francês organizado por CACALY (1997, p.370-2) temos que:

\begin{abstract}
"Uma linguagem documentária é uma linguagem artificial, uma metalinguagem, constituída de noções e de relações entre essas noções. Sua finalidade é de formalizar as noções contidas nos documentos e na expressão de solicitações de informações. É um sistema de representação sintético do conteúdo de textos. As linguagens documentárias constituem uma ponte entre a formulação de informações escritas no documento e a linguagem própria do solicitador de informações. De fato, elas servem para indexação e pesquisa documentária. (...) Enfim, são chamadas de "controladas" porque as palavras que as compõem devem ser utilizadas de forma idênticas na análise documentária e na pesquisa".
\end{abstract}

A definição acima sistematiza, de certo modo, grande parte das afirmações dos autores anteriormente citados.

Em 1998, GARCÍA GUTIÉRREZ volta a definir Linguagem Documentária, agora como "dispositivo léxico construído artificialmente para a análise e a recuperação de um sistema de informação" (GARCÍA GUTIÉRREZ, 1998, p.90). Neste trabalho, o autor afirma que as Linguagens Documentárias em geral ignoram o comportamento enunciativo (idem, p.13), e sugere trabalhar a Linguagem Documentária como uma linguagem associativa, baseada em estruturas de organização horizontal, criada a partir de cenários que reproduzem construções discursivas em uma área do conhecimento. Este novo instrumento o autor denomina Linguagem Epistemográfica (idem). No quinto capítulo apresentaremos as características dessa linguagem de forma mais detalhada. 
Pode-se afirmar que, a partir dos anos 80 , de acordo com os textos pesquisados ${ }^{6}$, portanto, todos os autores aqui citados passam a trabalhar com o termo Linguagem Documentária, que engloba características já levantadas desde os anos 60 , e que foram sucessivamente refinadas e enriquecidas. Assim, poderíamos dizer que:

Em relação à sua denominação, as Linguagens Documentárias foram chamadas de Léxico Documentário, Linguagem Informacional, Metalinguagem, Linguagem de Indexação, Linguagem Documental, Linguagem Classificatória, Linguagem Artificial, e Linguagem Controlada. Acreditamos que as Linguagens Documentárias trazem um pouco de cada um desses conceitos, e de certa forma conseguem abrangê-los; para demonstrar isso, propomos o seguinte quadro:

\begin{tabular}{|l|l|}
\hline \multicolumn{1}{|c|}{ Denominação } & \multicolumn{1}{c|}{ Abragência } \\
\hline Léxico Documentário & $\begin{array}{l}\text { Constituído por um léxico; } \\
\text { Tem regras de combinação; } \\
\text { É utilizado para o tratamento de documentos. }\end{array}$ \\
\hline Linguagem Informacional & $\begin{array}{l}\text { Sistema para levar informação dos documentos aos } \\
\text { usuários, Meio de comunicação. }\end{array}$ \\
\hline Linguagem de Indexação & Indexação de informações. \\
\hline Linguagem Classificatória & Classificação de informações. \\
\hline Linguagem Documental & $\begin{array}{l}\text { Termo adotado pelos autores espanhóis, e portugueses, } \\
\text { contrariamente ao que se adota no Brasil que é mais } \\
\text { próximo do uso francês. }\end{array}$ \\
\hline Linguagem Artificial & Linguagem construída, não natural. \\
\hline Linguagem Controlada & Seus termos e sua organização são normalizados. \\
\hline Metalinguagem & Descrevem a linguagem natural. \\
\hline
\end{tabular}

Quadro 1 - Linha Européia: Denominações para as Linguagens Documentárias

Quanto às suas funções, os autores concordam sobre o caráter organizador das Linguagens Documentárias, como também sobre seu papel de intermediação entre

${ }^{6}$ Os trabalhos da Espanha sobre o tema não foram objeto desta pesquisa, observando-se que muitos deles remetem à mesma matriz teórica inicial, Jean-Claude Gardin, com maiores ou menores ênfases às questões da linguagem. 
informação (do sistema) e usuário. São expressões que denotam as funções documentárias as relacionadas abaixo:

\begin{tabular}{|l|}
\hline \multicolumn{1}{|c|}{ Funções } \\
\hline Termos para indexação \\
\hline Recuperação de informação \\
\hline Classificação da informação \\
\hline Normalização da expressão \\
\hline Sistema simbólico para mediação \\
\hline Meio de Comunicação \\
\hline Descrição da Linguagem Natural \\
\hline
\end{tabular}

Quadro 2 - Linha Européia: Funções das Linguagens Documentárias

As Linguagens Documentárias também vão sendo refinadas quanto à proposição de suas características formais. De uma lista de termos, vão a léxico, passam a incorporar a necessidade de procedimentos sintáticos, até serem reconhecidas formalmente como estruturas com significação dada pelo uso. Ou seja, mais do que um instrumento com a função de indexar, as Linguagens Documentárias passam a ser reconhecidas como um tipo de linguagem.

Pelo exposto, nota-se que houve crescimento teórico na formulação das características que identificam uma linguagem para fins de indexação, fato que contribui enormemente para superar a noção de uma lista de termos usados para representar conteúdos de documentos. A noção de arranjo é progressivamente construída.

\subsubsection{A linha brasileira}

A linha brasileira, representada por integrantes do Grupo Temma, apresenta muito em comum com a linha européia. De fato, a linha nacional se institui e se firmou a partir do conhecimento teórico dos autores europeus, em particular, de Jean-Claude GARDIN. 
No Brasil, a questão das Linguagens Documentárias tem sido fortemente pesquisada por esse Grupo. Formado em 1986, o Grupo Temma é composto, em sua maioria, por pesquisadores e professores do Departamento de Biblioteconomia e Documentação da Escola de Comunicações e Artes da Universidade de São Paulo, e integra, também, alguns pesquisadores da UNESP-Marília. Sua preocupação principal se dirige à construção de conhecimentos relacionados à organização da informação ${ }^{7}$. Nota-se que o Grupo, inicialmente organizado em torno da noção de Análise Documentária, vai progressivamente alterando seu vocabulário para aproximá-lo das questões gerais de organização da informação. Antes, porém, de abordar esse aspecto, faremos uma retrospectiva do uso do termo Linguagem Documentária no Grupo.

Em 1983, CINTRA afirma que as Linguagens Documentárias "possuem uma gramática que corresponde a um conjunto de regras ou instruções (relações booleanas, indicadores de funções, etc)" (1983, p.5).

VALE (1987, p.14) trabalha com o conceito de Linguagem Documentária aproximandoo da linguagem de indexação, e diz que "A escolha de uma linguagem de indexação é fator essencial para a eficácia de um sistema de recuperação de informação".

No mesmo livro, CUNHA (1987, p.41) refere-se ao termo Linguagem Documentária apresentando-o como gênero de léxico que serve para a "conversão entre conceitos

\footnotetext{
${ }^{7}$ Mais informações sobre o Grupo Temma podem ser obtidas no Diretório dos Grupos de Pesquisa no Brasil, CNPq. http://dgp.cnpq.br/buscaoperacional/resultbusca.jsp?campo=grupo\&uf=branco\&instituicao=bran co\&grandearea $=$ branco\&area $=$ branco\&regini $=0 \&$ setor $=$ branco\&texto $=$ Grupo + Temma\&tipo=AN D [Acesso em: 14.12.2006].
} 
apresentados de forma independente nas diversas linguagens, e conceitos de leitura "universal" definidos pela própria Análise Documentária".

Em sua dissertação de mestrado, GUIMARÃES (1988, p.5) utiliza o termo linguagem de indexação para discutir a questão da recuperação de informações. Ele também a adota a divisão feita por CHAUMIER $^{8}$ (citado por GUIMARÃES, 1988, p.86), de linguagens de estrutura hierárquica, que abrangem os sistemas de classificação, e linguagens de estrutura alfabética ou combinatória, como os índices e tesauros.

Para GUIMARÃES, as Linguagens Documentárias são linguagens artificiais ou linguagens de indexação, que visam "ao controle do vocabulário e à padronização da linguagem no processo de busca" (1988, p.89), e preocupam-se com a transmissão do conteúdo dos documentos. Os termos dessas linguagens não teriam "em primeiro plano, o compromisso de serem fiéis ao vocabulário do usuário" (idem, p.103), mas uma fidelidade com o vocabulário especializado (idem, p.103).

No mesmo ano, FUJITA usa a expressão linguagem de indexação, cujo objetivo seria "representar o significado e o conteúdo dos documentos a serem recuperados através do índice" (FUJITA, 1988, p.24-25).

Em 1990, CUNHA define a Linguagem Documentária como uma "gramática, sintaxe construída a partir de um campo semântico previamente determinado" (1991, p.65). A autora propõe uma diferenciação quanto ao termo Linguagem Documentária, no singular, como sistema geral, e Linguagens Documentárias, no plural, como os

${ }^{8}$ CHAUMIER, J. Travail et méthode du/de la documentaliste: connaissance du problème. Paris: ESF / Libr. Techniques, 1980. 
“processos diversificados capazes de traduzir conteúdos de documentos em informações" (idem, p.19).

Em sua tese de doutorado, FUJITA (1992, p.17) trabalha com conceitos de VAN SLYPE ${ }^{9}$ para Linguagem Documentária ou linguagem de indexação, afirmando que é "um sistema de representação do conteúdo dos documentos e das perguntas, tendo como finalidade a recuperação dos documentos. Para isso é dotada de estrutura própria, controlada, padronizada e hierarquizada" e tem como objetivo "assegurar o controle do vocabulário para assuntos gerais e específicos". A autora considera o tesauro como a Linguagem Documentária mais característica.

TÁLAMO e outras (1992, p.197) introduzem no tratamento do tema Linguagem Documentária, as questões terminológicas:

"As Linguagens Documentárias são tradicionalmente consideradas instrumentos de controle terminológico que atuam em dois níveis: a) na representação da informação obtida pela análise e síntese de textos; b) na formulação de equações de busca da informação".

De acordo com LARA, "As LDs são tradicionalmente denominadas instrumentos comutadores ou de conversão, uma vez que permitem representar a informação presente numa determinada forma lingüística em outra forma, dita documentária" (LARA, 1993b, p.4 - nota de rodapé 2). A autora, em sua dissertação de mestrado, propõe observar outros aspectos das Linguagens Documentárias, como destacamos a seguir: a identificação das Linguagens Documentárias com "sistemas de significação,

\footnotetext{
${ }^{9}$ VAN SLYPE, G. Linguagem documentária e lingüística. Trad. Cordélia R. Cavalcanti. Brasília: UNB; Departamento de Biblioteconomia, 1983.
} 
com a função de normalizar os conceitos de área, controlar seu uso e viabilizar a interface documentação-usuário" (idem, p.66).

O texto de LARA propõe afinar as distinções entre a Linguagem Documentária e instrumentos que têm características parecidas. Para a autora as Linguagens Documentárias "não são taxionomia ou nomenclatura, não podendo pressupor, portanto, biunivocidade da relação significado-significante" (1993b, p.78). LARA propõe distinguir as Linguagens Documentárias dos léxicos, dos vocabulários, das nomenclaturas e das terminologias, como também das metalinguagens (idem, p.7071). Os léxicos seriam "conjunto das unidades que formam a língua de uma comunidade, atividades humana etc" (DUBOIS e outros, 1988, citado por LARA, 1993b, p.70); os vocabulários, “conjunto das ocorrências que integram um determinado corpus discursivo, como uma lista de unidade da fala" (DUBOIS e outros, 1973, citado por LARA, 1993b, p.70); a nomenclatura, um instrumento que pressupõe "biunivocidade da relação significante-significado" (DUBOIS e outros, citado por LARA, 1993b, p.70); as terminologias, "conjunto de termos de uma área, definidos rigorosamente para designar as noções que Ihes são úteis" (DUBOIS e outros, citado por LARA, 1993b, p.70), e a metalinguagem ,"uma semiótica cujo plano de conteúdo é, ele próprio, uma semiótica (HJELMSLEV, 1975, citado por LARA, 1993b, p.71). LARA afirma que as Linguagens Documentárias deveriam ser metalinguagens, "já que seu conteúdo pretende ser uma semiótica: um sistema de signos (e de significação) que se reporta a outro sistema de signos (e de significação)" (LARA, 1993b, p.71). Questiona, no entanto, como já afirmamos, a pertinência da equivalência, baseada na artificialidade da Linguagem Documentária e de seu caráter redutor. Ao afirmar que somente através da construção e uso rigorosos de instrumentos mediadores convenientes como as Linguagens Documentárias é que são geradas mensagens 
documentárias consistentes, LARA enfatiza a importância de uma característica comunicativa, tal como COYAUD havia feito antes.

Ainda em relação às Linguagens Documentárias como metalinguagens, LARA afirmar que "uma LD só seria uma metalinguagem se ela se consubstanciasse, de fato, como elemento da própria análise, ou seja, se ela funcionasse como instrumento de conhecimento" (LARA, 1993b, p.126). Essa afirmação aproxima a autora da visão de GARCÍA GUTIÉRREZ que, conforme se viu anteriormente, questiona a aplicabilidade do termo.

Mas é ao utilizar as referências à linguagem científica, feitas por GRANGER, que LARA propõe observar melhor a proximidade da Linguagem Documentária do sistema de significação das ciências (1993b, p.72), associando, a partir daí, as Linguagens Documentárias às terminologias. LARA afirma que uma Linguagem Documentária deve remeter ao simbolismo das ciências, "e não valer-se de sua incidência texto a texto". Assim, as Linguagens Documentárias não deveriam ser vistas apenas como denominações, mas a partir do conceito de representação, permitindo a separação do processo de elaboração das Linguagens Documentárias do processo de análise de textos com fins documentários (idem).

Pode-se identificar nessa passagem, uma preocupação que se tornará progressivamente mais clara em outros textos, em afirmar uma separação de procedimentos de Análise Documentária e de construção de Linguagens Documentárias.

O referencial terminológico, em LARA, é associado, também, à "enciclopédia como conceito", que "evidencia a necessidade de remissão à especialidade da área". A Terminologia como referencial enciclopédico contrapõe-se ao referencial do dicionário. 
Segundo a autora, o dicionário fornece meios para a interpretação da codificação lingüística, mas não permite recuperar a referência que é inerente ao texto (1993b, p.77). "Nesse sentido, a utilização da noção de enciclopédia como "hipótese reguladora", pode viabilizar a restituição de referências, se não dos textos propriamente ditos, pelo menos das significações conforme conceptualizadas pelas Ciências" (idem, p.78). E a Terminologia permite fornecer elementos "para a restituição de competências semânticas pertinentes, aumentando, dessa forma, a possibilidade de recuperação da informação e o desenvolvimento da semiosis" (idem, p.79). Assim:

\footnotetext{
"A partir dessas premissas, poderemos afirmar que se uma LD quiser funcionar como uma linguagem instrucional - e se quiser referir - ela não pode ser construída a partir de palavras do léxico, devendo, portanto, buscar referência na Terminologia. A Terminologia, ao referir-se a objetos concretos - ela sim se reporta aos discursos refere-se às palavras em funcionamento vinculadas a determinados contextos, o que Ihe possibilita exercer a função referencial de designação" (idem, p.83).
}

Em 1994, GUIMARÃES afirma que as Linguagens Documentárias são "os instrumentos (ferramentas) para que se efetue a tradução de conceitos anteriormente identificados e selecionados no documento" (1995, p.229). Para o autor, é possível dizer que "as estratégias de análise monitoram a utilização das linguagens de indexação e não vice-versa" (idem, p.5), e as linguagens de indexação seriam, então, uma decorrência desse processo, refletindo "um conjunto documentário em uma determinada realidade de busca informacional" (idem, p.9). A afirmação de GUIMARÃES difere, nesse sentido, da de LARA no que diz respeito à autonomia do processo de construção da Linguagem Documentária.

Em apostila de 1995, KOBASHI fala em Linguagens Documentárias e linguagens construídas. As primeiras seriam os sistemas de classificação e serviriam para 
classificação, enquanto que as outras seriam tesauros que serviriam para indexação (KOBASHI, 1995, p.7). Para a autora, as Linguagens Documentárias seriam formadas por um léxico reduzido e uma sintaxe precária (idem, p.41).

De modo retrospectivo, TÁLAMO (1997, p.2) afirma que somente por volta de 1970 o termo Linguagem Documentária afirmou-se na literatura, junto com a difusão do tesauro documentário, que é um tipo de Linguagem Documentária. Para ela, a atividade documentária não objetiva a organização como um fim em si mesma, mas como forma de tornar acessível e possibilitar a circulação efetiva da informação. Neste ponto nota-se que TÁLAMO retoma a divisão proposta na linha européia, onde o desenvolvimento das Linguagens Documentárias não é função da Análise Documentária, e sim um instrumento de organização:

"De fato, problemas relativos à comunicação passam a integrar o quadro de discussões da área no momento em que se tornar clara a importância da noção de linguagem. Evidencia-se que operar com o universo da linguagem não se confunde com a verbalização de denominações de classes pré-determinadas. Mais uma vez, o recurso à terminologia da área exemplifica suficientemente esse aspecto: a utilização do termo lista indica um instrumento de tratamento que se resume a uma sucessão de palavras, à uma forma de verbalização distante da noção de arranjo característica de uma linguagem. Já através dos termos, vocabulário, linguagem documentária e tesauro, reconhece-se a existência de um sistema que é simultaneamente um modo de organização de uma foram de comunicação da informação" (TÁLAMO, 1997, p.3).

A noção de Linguagem Documentária é aperfeiçoada quando TÁLAMO propõe vê-la como construção feita a partir de hipóteses sobre a organização do conhecimento que dêem conta de determinada demanda de informação, tendo por variáveis a instituição, a área de conhecimento, o tipo de atividade, e os segmentos sociais envolvidos (TÁLAMO, 1997, p.12). 
A autora ressalta, entretanto, que para que tal linguagem funcione efetivamente, ela deve ser construída de forma a garantir a presença de um sistema de relações que permita que ela se apresente como estrutura. Só dessa maneira é possível afirmar que suas unidades tenham significado e possam ser utilizadas como referência na representação dos textos que são objetos de sistemas documentários (idem, p.4). Vêse, aqui, a importância que a autora confere à noção de estrutura (Discutiremos esta noção no terceiro capítulo).

Contrariamente à LARA, TÁLAMO fala da Linguagem Documentária como metalinguagem. TÁLAMO afirma que, em relação ao conhecimento registrado, a LD é uma metalinguagem que o reelabora como informação. Pode-se afirmar que a autora recupera a abordagem de GARDIN tornando-a mais clara, conferindo à Linguagem Documentária algo que não foi reconhecido por GARCÍA GUTIÉRREZ e LARA em relação à identificação de Linguagem Documentária e metalinguagem. Verifica-se que, do mesmo modo, que a autora enfatiza a noção de estruturação como sistema de relacionamento interno à própria Linguagem Documentária, quando afirma que, assim como a relação entre a linguagem natural e a realidade, a Linguagem Documentária não se define em relação a acervos, mas "por força das relações que respondem pela organização da hipótese de representação do conhecimento" (TÁLAMO, 1997, p.1012). A autora dá o seguinte exemplo (idem, p.6):

\footnotetext{
"uma lista de palavras cuja organização se resume à ordenação alfabética de seus elementos nada representa (...) porque nada significa. Podemos sim interpretá-la, mas ao fazê-lo, recorremos a algum sistema de significação, o que equivale a dizer quer tal lista poderá ter tantos significados quanto forem os sistemas considerados, segundo os utilizadores envolvidos".
} 
A definição mais formal de Linguagem Documentária proposta por TÁLAMO (idem, p.10) é a que segue:

"De maneira geral, define-se linguagem documentária (LD) como uma linguagem construída, oposta à natural, portanto, que tem como objetivo específico tratar a informação para fins de recuperação. Atualmente as questões relativas à sua construção são tratadas pela Lingüística Documentária e aquelas relativas ao seu uso encontramse integradas às questões mais amplas relativas ao tratamento e à recuperação da informação, discutidas no âmbito da Análise Documentária $(A D) "$.

A questão das hipóteses de organização é reiterada por LARA (1999, p.60), que afirma que as Linguagens Documentárias são instrumentos de representação documentária que servem para promover a circulação de informações. As representações só podem ser reconhecidas a partir de hipóteses de organização da informação. Assim, LARA afirma que as Linguagens Documentárias, para se constituírem em instrumento de comunicação devem: "funcionar como código inteligível, caracterizar-se como metalinguagem, funcionar como fonte para interpretação de sentido, e incorporar o usuário como integrante do processo" (idem, p.108).

TÁLAMO (2001, p.145-6) afirma que se acredita "que a linguagem documentária tem a sua origem na elaboração dos enunciados condensados que acompanhavam as formas mais primitivas de registro".

LARA, em 2002, novamente comenta o fato da Linguagem Documentária ser uma maneira de organizar a informação para mapear uma área e transferi-la a determinados grupos que apresentam objetivos específicos. Para a autora, "a 
linguagem documentária configura-se como instrumento facilitador da comunicação em contextos documentários específicos" (LARA, 2002b).

No mesmo trabalho, a autora complementa a discussão (LARA, 2002b):

"Aliados a princípios de organização lógica, o uso de parâmetros lingüísticos levou à compreensão de que uma linguagem documentária deve ser formulada pelo relacionamento entre suas unidades e não simplesmente pela mera presença dos termos oriundos de processos de extração. Tal rede de relacionamentos leva à estruturação do conjunto dos termos a partir de relações do tipo hierárquico, associativo e de equivalência, o que permite que ela funcione, mais propriamente, como instrumento de mediação entre sistema e usuário, ou melhor, entre a linguagem do sistema e a linguagem do usuário".

Para CINTRA e outras (2002, p.15), “com os limites próprios de uma linguagem construída, as linguagens documentárias - LDs - se valem de quase todos os conceitos apresentados para a LN [linguagem natural], constituem sistemas onde as unidades se organizam em relações de dependência". Para as autoras, "compete às LDs transformar estoques de conhecimento em informações adequadas aos diferentes segmentos sociais (idem, p.16-7).

CINTRA e outras (idem, p.33) afirmam que as Linguagens Documentárias são "construídas para indexação, armazenamento e recuperação da informação e correspondem a sistemas de símbolos destinados a 'traduzir' os conteúdos dos documentos".

Em outro trabalho (LARA, 2003), em comentário a HUTCHINS (1975) que afirma que as unidades da Linguagem Documentária são signos que estabelecem relações entre a forma física dos descritores e o conteúdo informacional representado (seus 
referentes), LARA observa que não há uma relação biunívoca entre o que é representado e a forma da representação, já que a Linguagem Documentária é, em si, um sistema de significação construído a partir de uma hipótese de significação, o que significa dizer que ela é, também, um signo particular.

A autora reafirma, também, o caráter estrutural das Linguagens Documentárias:

"Uma linguagem documentária só poderá ser propriamente linguagem se tiver características estruturais que a permitam funcionar como tal. É por essa razão que as linguagens documentárias mais modernas, como os tesauros, apresentam-se como estruturas, que compreendem relações de natureza lógica, ontológica, associativa e de equivalência. O léxico de uma linguagem documentária se organiza como uma rede paradigmática e dispõe de regras de combinação (rede sintagmática), que a despeito das diferenças relativamente à potencialidade de produzir enunciados como os de língua, permite a formação de sintagmas, combinação de conceitos que podem expressar temas informacionais".

Como lembram BOCCATO e FUJITA (2006, p.28) “a linguagem documentária, enquanto veículo de comunicação, deve representar os campos conceituais respeitando a cultura da comunidade à qual a linguagem serve”.

Portanto, podemos verificar ao longo dos anos, a afirmação do termo Linguagem Documentária como um conceito enriquecido, agregando àquele apresentado pela vertente européia, outras características que enfatizam seu caráter de 'linguagem'.

A breve revisão permite ver que prevaleceu o termo Linguagem Documentária sobre o termo linguagem de indexação nas linhas européia e brasileira (esta última, ao menos no âmbito do Grupo Temma), o que permite afirmar que seu desenvolvimento 
corrobora uma visão mais abrangente do instrumento de indexação ao ressaltar os aspectos que reforçam as características de linguagem.

Reconhece-se a função de metalinguagem da Linguagem Documentária, e se propõe incorporar à sua elaboração hipóteses de organização do conhecimento, que devem respeitar os interesses e necessidades de variáveis como os usuários, a instituição que gera e organiza a informação, a área de conhecimento ou atividade, entre outros. De um léxico reduzido e sintaxe precária, ela passou a ser elaborada seguindo parâmetros lingüísticos sendo, portanto, compreendida como uma estrutura cujos termos devem necessariamente estar relacionados para que possam significar de modo determinado.

Fora do Grupo Temma, a questão da Linguagem Documentária também é observada por DODEBEI, em seu livro 'Tesauro'. A autora afirma que as Linguagens Documentárias são metarrepresentações ou representações documentárias (DODEBEl, 2002, p.39), e são consideradas:

"metacódigos ou metalinguagens, pois são construções artificiais ou convenções criadas para facilitar o conhecimento de um domínio, regidas por regras de utilização. (...) As LD são construídas a partir da $\mathrm{LN}$, quer dizer, tomam como modelo as relações paradigmáticas e as relações sintagmáticas existentes entre as palavras (idem, p.53).

Para a autora, entre as funções da Linguagem Documentária estão: a função de organizar um campo conceitual, a função de servir como instrumento para a distribuição de documentos, e a função de controlar dispersões léxicas nos processos de análise documentária (idem, p.57). 
$\mathrm{Na}$ linha brasileira, identificamos um aproveitamento e aprofundamento das questões levantadas pela linha européia. Para continuar as sistematizações, podemos propor o quadro que co-relaciona denominações à abrangência de aplicação dos termos:

\begin{tabular}{|l|l|}
\hline \multicolumn{1}{|c|}{ Denominação } & \multicolumn{1}{c|}{ Abragência } \\
\hline Linguagem de Indexação & $\begin{array}{l}\text { Indexação de informações } \\
\text { Recuperação de Informações } \\
\text { Controle do vocabulário } \\
\text { Tradução de conceitos } \\
\text { Uso de Tesauros e Índices } \\
\text { Léxico Reduzido } \\
\text { Regra de Uso }\end{array}$ \\
\hline Linguagem Classificatória & $\begin{array}{l}\text { Classificação de informações } \\
\text { Uso de Esquemas de Classificação }\end{array}$ \\
\hline Linguagem Artificial & Linguagem construída, não natural \\
\hline Metalinguagem & Reelaboração do conhecimento como informação \\
\hline Linguagem Construída & $\begin{array}{l}\text { Oposta a Natural } \\
\text { Recuperação de Informação } \\
\text { Tratamento da Informação }\end{array}$ \\
\hline
\end{tabular}

Quadro 3 - Linha Brasileira: Denominações das Linguagens Documentárias

Quanto às funções, observamos a ênfase na questão de significação das Linguagens

Documentárias, preocupação ligada à necessidade de circulação de informações:

\begin{tabular}{|l|}
\hline \multicolumn{1}{|c|}{ Funções } \\
\hline Conversão de conceitos \\
\hline Recuperação de informação \\
\hline Classificação da informação \\
\hline Controle do vocabulário \\
\hline Controle Terminológico \\
\hline Transmissão de conteúdo \\
\hline Sistema simbólico para mediação \\
\hline Meio de Comunicação \\
\hline Descrição da Linguagem Natural \\
\hline Representação das perguntas ao sistema \\
\hline Sistemas de Significação \\
\hline Construção feita a partir de hipóteses sobre a organização do conhecimento \\
\hline Propiciar a circulação de informação \\
\hline
\end{tabular}

Quadro 4 - Linha Brasileira: Funções das Linguagens Documentárias 
Atualmente, observa-se, no Grupo Temma, que determinados autores têm investido nos estudos das relações entre a Linguagem Documentária e a Terminologia. Postergaremos a discussão para centrarmo-nos nos aspectos comparativos que permitem falar das principais características da Linguagem Documentária analisadas até agora neste trabalho.

\subsection{Quadro Comparativo sobre os Conceitos de Linguagem}

\section{Documentária}

A partir do levantamento feito anteriormente, podemos propor uma sistematização dos conceitos de Linguagem Documentária. Reunimos, nos quadros a seguir, aspectos das Linguagens Documentárias relativos à sua estrutura, características e funções.

\begin{tabular}{|c|c|c|}
\hline Estrutura & Características & Funções \\
\hline $\begin{array}{ll}- & \text { Léxico de noções ou } \\
\text { conjunto de termos; } \\
\text { - } & \text { Sistema estrutural de } \\
\text { relações; } & \\
\text { - } & \text { Conjunto de regras e } \\
\text { símbolos; } \\
\text { Hipótese para a } \\
\text { organização dos termos } \\
\text { (organização da } \\
\text { informação); } \\
\text { - Parâmetros lingüísticos e } \\
\text { terminológicos como base } \\
\text { da organização dos } \\
\text { termos }\end{array}$ & $\begin{array}{l}\text { Linguagem construída, } \\
\text { Metalinguagem; } \\
\text { Sistema de representação } \\
\text { sintético para representar } \\
\text { o conteúdo de } \\
\text { documentos; } \\
\text { - Ponte entre os } \\
\text { documentos e os } \\
\text { usuários. }\end{array}$ & $\begin{array}{ll}\text { - } & \text { Organização ou } \\
\text { classificação dos dados de } & \text { um campo científico; } \\
\text { - } & \text { Indexação, } \\
\text { armazenamento, } \\
\text { recuperação de } \\
\text { informação; } \\
\text { - Tradução de documentos } \\
\text { e solicitações; } \\
\text { - } \quad \text { Controle terminológico; } \\
\text { - Condensação dos } \\
\text { conteúdos; } \\
\text { - Normalização da } \\
\text { expressão; } \\
\text { Organização dos termos } \\
\text { em classes semânticas; } \\
\text { - Instrumento de } \\
\text { representação de } \\
\text { conhecimento; } \\
\text { Visualização do mapa de } \\
\text { conhecimento de uma } \\
\text { área; } \\
\text { Reelaboração do } \\
\text { conhecimento como } \\
\text { informação }\end{array}$ \\
\hline
\end{tabular}

Quadro 5 - Estrutura, Características e Funções das Linguagens Documentárias 
As Linguagens Documentárias, portanto, funcionam como Instrumento de comunicação para contextos específicos, como uma construção que atende, simultaneamente, aos objetivos e necessidades de seus usuários, da instituição que produz e organiza o conhecimento, das atividades, etc.

Pelo exposto, verifica-se que as Linguagens Documentárias utilizam, em sua elaboração, referências a parâmetros lingüísticos, principalmente os da lingüística estruturalista. Para que essa observação se torne mais clara, procuraremos explorar melhor a noção de estrutura no quadro da Lingüística Estruturalista, verificando, depois, suas influências na Documentação via Lingüística Documentária. 


\section{A Lingüística Estruturalista e a Noção de Estrutura}

A Lingüística Estruturalista foi desenvolvida por Saussure, sendo divulgada em 1916, quando do lançamento do Curso de Lingüística Geral (CLG), publicado por seus alunos de acordo com anotações de aula. O foco do Cours é a língua como sistema (PAVEAU e SARFATI, 2006, p.63). De fato, o termo 'estrutura' está ausente do Cours Saussure falava em 'sistema' -, mas foi utilizado pelos seus seguidores. A partir de então, a noção de estrutura passou a permear diversas áreas de conhecimento além da Lingüística, como a Psicanálise, a Semiologia, entre outras (LEPARGNEUR, 1972), e também a Ciência da Informação.

Procuraremos, a seguir, verificar, o que se entende por Lingüística Estruturalista e compreender a noção de estrutura. As dicotomias propostas por Saussure, que sempre remetem à noção de sistema ou estrutura, também serão explicitadas tomando como fonte a literatura da Lingüística Estruturalista.

É preciso ressaltar que o conceito de estrutura, assim como a teoria estruturalista estrita, tem sido objeto de inúmeros desenvolvimentos desde a publicação do Cours. Permanece, no entanto, sua importância como base para os futuros desenvolvimentos.

\subsection{A Lingüística Estruturalista}

A lingüística ocidental tem origem greco-romana, mas os gregos a estudavam como um objeto da filosofia, em vez de pesquisar seu funcionamento. Na Idade Média, a linguagem era tida como simples reflexo das coisas. De acordo com DOSSE (1993), o

termo 'estrutura', que remetia ao âmbito da arquitetura e da construção, remetia somente à idéia de algo físico, como um prédio, em construção. Entre os séculos XVII 
e XVIII, o sentido do termo ampliou-se e passa a envolver os seres vivos: o corpo e a língua passaram a ser vistos como estrutura; entendia-se estrutura como "descrição da maneira como as partes integrantes de um ser concreto organizam-se numa totalidade" (1993, p.15). Já na Idade Clássica, percebeu-se que a ciência se articulava em torno de nomenclaturas; e no século XIX veio a noção de que a linguagem ultrapassa a palavra, tendo suas raízes no pensamento humano (LEPARGNEUR, 1972, p.82-3).

Em 1916, com Saussure, surge uma nova noção da lingüística, salientando-se a importância do estudo dos seus elementos formais. Reconheceu-se que toda língua, escrita ou não, é interessante. A língua forma uma estrutura, um arranjo sistemático de partes criando numerosas combinações. O significado das palavras é resultado das relações de oposição determinadas no interior do sistema (BENVENISTE, 1991, p.1932; LOPES, 1987, p.15-71). Para DOSSE, é entre 1900 e 1926 que a noção de estrutura dá origem ao 'estruturalismo', nas áreas da ciência humanas. Mas apenas afirma-se de fato, em sua acepção moderna, com a evolução lingüística:

"A estrutura da então origem ao que o Vocabulaire de André Lalande qualifica de neologismo: o estruturalismo, entre 1900 e 1926. O estruturalismo nasce nos psicólogos, para opor-se à psicologia funcional no começo do século, mas o verdadeiro ponto de partida do método em sua acepção moderna, na escala de todas as ciências humanas, provém da evolução lingüística. Se Saussure emprega apenas em três ocasiões o termo "estrutura" no Curso de Lingüística Geral, é sobretudo a Escola de Praga (Troubetzkoy e Jakobson) que vai definir o uso dos termos estrutura e estruturalismo. A referência ao termo estruturalismo como programa fundador, tendência especificada por seu método de abordagem, é reivindicada pelo lingüista dinamarquês Hjelmslev, que funda em 1939 a revista Acta Linguistica, cujo primeiro artigo trata de "lingüística estrutural". A partir desse núcleo lingüístico, o termo vai provocar uma verdadeira 
revolução de todas as ciências humanas em pleno século XX. Elas vão pensar que adquiriram aí a sua ata de batismo científico" (DOSSE, 1993, p.15-16).

Mais precisamente, segundo BENVENISTE (1976, p.20-22), a lingüística desenvolveuse em três fases:

- $1^{a}$ fase: Gregos e o interesse filosófico: "Raciocinavam sobre sua condição original [da língua] - a linguagem é natural ou convencional? - muito mais do que Ihe estudavam o funcionamento";

- $\quad 2^{a}$ fase: Língua e a abordagem histórica: língua objeto de especulação e não de observação. Até o século XVIII. A partir do século XIX estudo de línguas indo-européias, genética, evolução das línguas;

- $\quad 3^{a}$ fase: 1916: CLG de Saussure e abordagem descritiva: "estudar e descrever por meio de uma técnica adequada a realidade lingüística atual” sem pressupostos teórico ou histórico. Estuda-se uma realidade intrínseca da língua: "em que consiste e como funciona uma língua".

Assim, não foi Saussure quem denominou sua lingüística de estruturalista, mas seus seguidores, mais notadamente os pesquisadores da Escola de Praga e Hjelmslev.

Para HJELMSLEV ${ }^{10}$ (1944, citado por BENVENISTE, 1971, p.30):

"Entende-se por lingüística estrutural um conjunto de investigações baseadas numa hipótese segundo a qual é cientificamente legítimo descrever a linguagem como uma entidade essencialmente autônoma de dependências internas ou, numa palavra uma estrutura... A análise desta entidade permite separar constantemente as partes que se condicionam reciprocamente, cada uma das quais depende de certas

${ }^{10}$ In: Revista Acta linguistica, IV, fascículo. 3, p.V. 
outras e não seriam concebíveis nem definíveis sem essas outras partes. Ela reduz seu objeto a uma rede de dependências, ao considerar os fatos lingüísticos como função uns dos outros"

A língua é, para Saussure, essencialmente, um instrumento de comunicação (LOPES, 1987). É através da linguagem que se realiza a comunicação entre os homens. É ela que permite, entre outras coisas, a troca de informações. A comunicação só é possível através da linguagem.

"As idéias de Saussure que deram início à lingüística contemporânea destacam a questão do valor relacional dos elementos lingüísticos, da auto-suficiência do sistema, da necessidade de dissociar uma lingüística de estado (sincrônica) da lingüística evolutiva (diacrônica), da natureza do signo e da distinção langue/parole" (idem, p.73).

Tais princípios constituem a proposição de leis gerais do funcionamento de uma língua (LEPARGNEUR, 1972, p.6).

Observa-se que:

"O funcionamento da linguagem não é, segundo Saussure, um fator anárquico, que coloque em perigo seu caráter organizado. De uma forma positiva, agora, Saussure mostra que a linguagem, a todo o momento de sua existência, deve apresentar-se como uma organização. Essa organização inerente a toda língua, Saussure chama de sistema (seus sucessores falam muito de estrutura). A nuança particular que os saussurianos introduziram nesses termos (e que se soma a idéia geral de ordem e de regularidade), é que os elementos lingüísticos não preexistem ao relatos que eles mantém no interior da organização do conjunto da língua. Esta não se sobrepõe àquelas, mas as constitui, os termos não tendo realidade lingüística a não ser por suas relações mútuas. Um "sistema" ou "estrutura" é assim uma organização cujos elementos não têm nenhuma característica própria independentemente de suas relações mútuas no interior do todo" (DUCROT e SCHAEFFER, 1995, p.36-7). 
Para GARCÍA GUTIÉRREZ, o estruturalismo lingüístico é "conjunto de teorias e métodos que se acumularam em torno da posição saussureana" (GARCÍA GUTIÉRREZ, 1990, P.34-35).

O estruturalismo lingüístico ou a lingüística estrutural acaba por questionar "a tese da degradação das línguas partindo do princípio de que a língua é fundamentalmente, e não por acidente, um instrumento de comunicação, um modo de vida social" (TÁLAMO,1997, p.4). Essa alteração significa o rompimento com uma lingüística diacrônica para uma lingüística sincrônica, onde a noção de valor relacional assume uma função de extrema importância. Através dela é possível observar a língua em si mesma, tal como se apresenta enquanto sistema de relações entre partes.

A noção estrutural é, de fato, a responsável pela nova proposta. Conforme afirmam RADFORD e RADFORD (2005, p.61) “O coração da lingüística de Saussure é a seguinte proposição: uma linguagem é um sistema no qual todos os elementos se encaixam, e o valor de qualquer elemento depende da coexistência simultânea de todos os outros".

Para MERLEAU-PONTY"11 (1960, p.49, citado por DOSSE, 1993, p.60) "O que aprendemos em Saussure é que os signos, um por um, nada significam, que cada um deles exprime menos um sentido que assinala uma diferença de sentido entre ele próprio e os outros".

DOSSE afirma que o essencial no Cours de Saussure consiste em "fundamentar o arbitrário do signo, em mostrar que a língua é um sistema de valores constituído não

${ }^{11}$ MERLEAU-PONTY, M. Signes. Paris: Gallimard, 1960. 
por conteúdos ou produtos de uma vivência, mas por suas diferenças puras" (1993, p.65).

Para ECO (1997, p.269),

\begin{abstract}
"O que o estruturalismo lingüístico tornou evidente, já vimos, não foi o fato de uma estrutura ser um sistema de partes solidárias e interdependentes, mas o fato de que essa estrutura possa ser expressa em termos de oposições e diferenças, independentemente dos elementos que passam a colmar as valências constituídas pelos pólos oposicionais e diferenciais. Em decorrência, a metodologia estruturalista mostra-se capaz de analisar unidades relacionadas e organizadas".
\end{abstract}

\title{
3.2. A noção de estrutura
}

A principal contribuição do estruturalismo, para LARA, é a "possibilidade de entender que o continuum da realidade estrutura-se na descontinuidade das línguas. Os distintos códigos são estruturados e desestruturados a partir de infinitas possibilidades" (LARA, 1999, p.85).

De acordo com PAVEAU e SARFATI, Saussure, no Cours de Linguistique General $C L G$, discutia a questão de sistema, que pode ser entendido como "um conjunto que constitui um todo orgânico" (PAVEAU e SARFATI, 2006, p.89). Esse todo orgânico se organiza por meio de relações entre os elementos, de modo que cada elemento interfere no outro, formando um sistema ou uma estrutura.

Pode-se dizer, de acordo com DODEBEI, que "na atualidade, um sistema é visto como um conjunto de elementos, propriedades e relações, podendo ser definido como um conjunto de elementos em interação, que realizam determinadas funções para determinados propósitos" (2002, p.22). 
DUCROT (1968, citado por PAVEAU e SARFATI, 2006, p.89-90) afirma que o entendimento de estrutura como uma organização regular sempre fez parte dos estudos das línguas, e que a grande novidade do estruturalismo foi a de dar uma nova significação ao termo.

Mas o que vem a ser a estrutura, do ponto de vista lingüístico? Para LEPARGNEUR (1972, p.4-5), "uma estrutura é um conjunto de elementos entre os quais existem relações de forma", de modo que: "toda modificação de um elemento acarreta modificações dos outros elementos e relações. A estrutura é a concretização de certas leis que procuram e mantêm certo equilíbrio num conjunto que, na perspectiva em questão, pode ter sido considerado fechado" (idem).

Como bem observa BENVENISTE (citado por LOPES, 1997, p.97), "A noção de estrutura está intimamente ligada à noção de relação no interior de um sistema", constituindo, para HJELMSLEV (citado por LOPES, 1987, p.39), "um modelo, ou seja, uma construção mental que serve de hipótese de trabalho". A estrutura não se compõe de coisas, mas de relações.

Para GREIMAS e COURTÉS (1979, p.162), "sendo definida como uma rede relacional, estrutura remete ao conceito de relação e pressupõe, para ser eficaz em semiótica, uma tipologia das relações".

É de responsabilidade de GREIMAS a proposição de um modo de ver a estrutura mínima da significação.

GREIMAS põe em relevo que a língua é feita de oposições. Para o autor, enfocar o problema da significação requer "afirmar a existência de descontinuidades, no plano da percepção, e dos espaços diferenciais (...) criadores de significação, sem se 
preocupar com a natureza das diferenças percebidas" (LOPES, 1987, p.313). Derivam daí duas concepções que se complementam:

1a. Concepção de estrutura: "O mundo toma forma diante de nós porque percebemos diferenças".

Perceber diferenças quer dizer:

a) captar ao menos dois termos-objeto como simultaneamente presentes;

b) captar a relação entre os termos, ligá-los de um ou de outro modo.

Decorre daí uma primeira definição de estrutura que remete à presença de dois termos e da relação entre eles. Conseqüentemente, um só termo-objeto não comporta significação. Do mesmo modo, a significação pressupõe a existência da relação: é o aparecimento da relação entre os termos que é a condição necessária da significação.

$2^{a}$. Concepção de estrutura: $O$ aprofundamento da noção de estrutura, para GREIMAS, remete às noções de conjunção e disjunção, associadas à de relação, de forma que:

"1) Para que dois termos possam ser captados juntos é preciso que tenham algo em comum (semelhança, identidade)", ou seja, conjunção;

2) Para que dois termos possam ser distinguidos, é preciso que sejam diferentes, qualquer que seja a forma (problema da diferença e da não identidade)", ou seja, disjunção.

GREIMAS sintetiza tais idéias afirmando que a relação é ao mesmo tempo disjuntiva e conjuntiva e denomina de estrutura elementar um tal tipo de relação. "Já que os termos-objetos não comportam, isoladamente, nenhuma significação, é ao nível 
dessas estruturas e não ao nível dos termos-objetos (os elementos dela) que devem ser procuradas as unidades significativas elementares (...) A língua não é um sistema de signos, mas uma reunião de estruturas de significação" (LOPES 1987, p.313)

Na visão de LEPARGNEUR (1972, p.26),

\begin{abstract}
"O que interessa à análise estrutural de um sistema são as diferenças entre um termo e outro. O que interessa num sintagma é a coordenação dos termos: o sentido de cada um vem de seu relacionamento como outros elementos do mesmo conjunto."
\end{abstract}

Portanto, o método estruturalista consiste em manipular diferenças e relações.

Verifica-se que, desde Saussure, a noção central é a de valor. Como afirma DASCAL, "Quem diz 'sistema, com efeito, diz que os elementos se equilibram reciprocamente segundo regras determinadas'. É, portanto, o conjunto de suas oposições ou diferenças que conta para determinar sua natureza. É nesse sentido que se pode afirmar que as unidades de um sistema semiológico são de natureza puramente diferencial. É uma outra maneira de dizer que a noção de valor recobre aquelas de unidade, de entidade concreta e de realidade, ou ainda que a noção de identidade se confunde com aquela de valor e reciprocamente"12 (DASCAL, 1978).

Das idéias acima repertoriadas, pode-se propor uma sistematização. A noção de estrutura é identificada pela presença dos seguintes traços:

\footnotetext{
${ }^{12}$ Tradução livre para uso didático, M.L.G.Lara (1998).
} 


\begin{tabular}{|l|l|}
\hline \multicolumn{1}{|c|}{ Traços } & \multicolumn{1}{c|}{ Características } \\
\hline Sistema, Conjunto & $\begin{array}{l}\text { É uma idéia que remete a um conjunto de elementos que se } \\
\text { relacionam mutuamente; }\end{array}$ \\
\hline $\begin{array}{l}\text { Relações entre } \\
\text { elementos }\end{array}$ & $\begin{array}{l}\text { Seus elementos não têm características próprias } \\
\text { isoladamente, mas sim em relação uns com os outros; }\end{array}$ \\
\hline Construção & É uma construção que serve de hipótese de trabalho; \\
\hline Noção de valor & É apoiada na noção de valor, que co-relaciona termos; \\
\hline Diferenças & Remete a um método que trabalha com diferenças e relações; \\
\hline $\begin{array}{l}\text { Significação via } \\
\text { relação }\end{array}$ & $\begin{array}{l}\text { Permite ver a significação como uma estrutura elementar que } \\
\text { coloca em jogo dois termos vinculados por uma relação. }\end{array}$ \\
\hline
\end{tabular}

\section{Quadro 6 - Traços da Noção de Estrutura}

\subsection{As Dicotomias de Saussure}

Associada à idéia de sistema ou estrutura, no seu Curso de Lingüística Geral - CLG, Saussure introduz dicotomias fundamentais para a discussão da lingüística. São elas: língua/fala (langue/parole), significado/significante, diacronia/sincronia, forma/substância, paradigma/sintagma. Apresentaremos brevemente todas elas, destacando por último a questão dos paradigmas e sintagmas, que é a que mais nos interessa observar para este trabalho (LOPES, 1987, 1997).

\section{A) Língua e Fala (Langue e Parole):}

A língua (langue) é um sistema de regras que determina o emprego das formas coletivas convencionais necessárias para a comunicação. A língua é fruto de um pacto social, uma espécie de modo de ver a realidade, construída por toda a comunidade e que nenhum falante em particular tem a autoridade para alterar. É, sobretudo, um conceito social que se concretiza no discurso (parole), que é a utilização local e ocorrencial de uma língua. Como a língua (langue) é um sistema de possibilidades, e um sistema de relações no qual cada termo assume seu valor somente em relação a um outro termo, a norma aparece como o conjunto de realizações dessas possibilidades. A norma precisa ser comprovada concretamente, seguida dentro de 
um grupo, e implica na eliminação de tudo que na parole é inédito como, por exemplo, as variantes individuais. A langue é o código de falantes desse idioma.

Acionada pela enunciação própria a cada ato concreto de comunicação, a língua propicia uma liberdade de combinações, tornando sua utilização diferencial e sempre parcial. A linguagem, além de ser o resultado da soma da língua com o discurso é, também, um sistema de valores, pois cada um de seus elementos define-se somente em relação aos outros com os quais forma o sistema.

Assim, podemos resumir as características de língua e fala no seguinte quadro:

\begin{tabular}{|l|l|}
\hline \multicolumn{1}{|c|}{ Língua (langue) } & \multicolumn{1}{c|}{ Fala (parole) } \\
\hline Sistema de regras & Uso local e ocorrencial de uma língua \\
\hline Sistema supra-individual & Enunciação concreta \\
\hline Pacto social, convencional & Liberdade de combinações \\
\hline $\begin{array}{l}\text { Material - léxico e gramatical - } \\
\text { estocado }\end{array}$ & $\begin{array}{l}\text { Uso parcial, diferencial, realizador e } \\
\text { atualizador }\end{array}$ \\
\hline
\end{tabular}

Quadro 7 - Língua e Fala

\section{B) Significado e Significante}

As unidades da língua são os signos lingüísticos que são organizados por uma relação entre significado (conceito, plano de conteúdo) e significante (imagem acústica, plano de expressão). O signo lingüístico é arbitrário, ou seja, não há nenhum tipo de relação intrínseca ou de casualidade entre diferentes significantes e o significado a que se unem, e nem o significado é escolhido pelo falante. O que se tem, na verdade, é um vínculo natural com o conteúdo. O signo é arbitrário absoluto, quando tomado isoladamente, mas é arbitrário relativo, quando no elemento componente de uma estrutura lingüística (GREIMAS, 1976, p.27-41; LOPES, 1987, p.72-96; LOPES, 1997, p.91-110). 
No entanto, como lembra ECO, é um grande equívoco

\begin{abstract}
"considerar, por exemplo, um termo como a união de determinado som com determinado significado, porque isso significaria isolá-lo do contexto de que faz parte e acreditar que se possa começar pelos termos para construir o sistema fazendo-lhes a soma, ao invés de partir do todo solidário para chegar, mediante análise, aos elementos que encerra" (ECO, 1997, p.259).
\end{abstract}

O signo apresenta, resumidamente, as seguintes características:

\begin{tabular}{|l|l|}
\hline \multicolumn{1}{|c|}{ Traços } & \multicolumn{1}{c|}{ Características } \\
\hline Unidade Dupla & Presença e ausência, cuja relação denomina-se significação \\
\hline Institucional & Existe apenas para um grupo definido de utilizadores \\
\hline Imotivado & Não há relação intrínseca entre significante e significado \\
\hline $\begin{array}{l}\text { Significação não é } \\
\text { Representação }\end{array}$ & $\begin{array}{l}\text { A linguagem representa algo, isto é, por força da significação ela } \\
\text { se propõe no lugar de algo, o substitui. Uma lista de palavras em } \\
\text { ordem alfabética nada representa, pois nada significa. Para } \\
\text { interpretá-la recorremos a um sistema de significação. }\end{array}$ \\
\hline
\end{tabular}

\title{
Quadro 8 - Características do Signo
}

\section{C) Diacronia e Sincronia}

A possibilidade de falar em valor relacional dos elementos lingüísticos decorre do fato de Saussure propor ver a língua como um sistema auto-suficiente considerado em si mesmo. É a noção de sincronia que permite remeter à análise do sistema, ou à linguagem em si; a diacronia, por seu lado, permite se referir às mudanças sofridas pelos elementos desse sistema ao longo do tempo. Não existe, porém, sincronia pura, uma vez que no interior de qualquer sistema coexistem estágios de sistemas anteriores, e nele formam-se estágios posteriores.

Dessa forma, temos, resumidamente, a seguinte comparação entre diacronia e sincronia: 


\begin{tabular}{|l|l|}
\hline \multicolumn{1}{|c|}{ Diacronia } & \multicolumn{1}{c|}{ Sincronia } \\
\hline Evolução & Simultaneidade, coexistência \\
\hline Dois estados sucessivos & Mesmo estado \\
\hline
\end{tabular}

Quadro 9 - Diacronia e Sincronia

D) Forma e Substância

Saussure afirma que a língua é um sistema de formas e regras e não de substâncias. Isso porque cada elemento de uma língua qualquer só pode ser definido em relação aos seus demais elementos e por sua função dentro do sistema, nunca por suas propriedades físicas, que seriam as substâncias (LOPES, 1987, p.79-80).

De acordo com ECO, "A mensagem como forma significante surge como uma forma vazia a que se podem atribuir os mais diferentes significados" (1997, p.46).

No processo de tradução de um idioma a outro, observamos essa dicotomia: não há diferença na significação do ponto de vista semântico, uma vez que uma língua pode ser traduzida em outra. A diferença encontra-se na forma em que a significação se apresenta em cada uma dessas línguas (TÁLAMO, 1997, p.7). Assim, a língua é forma, e não substância (SAUSSURE, 1972, p.151, citado por LOPES, 1997, p.99). E através dessa forma propormos construções de relações que geram significação.

Resumidamente, temos as seguintes características:

\begin{tabular}{|l|l|}
\hline \multicolumn{1}{|c|}{ Forma } & \multicolumn{1}{c|}{ Substância } \\
\hline Expressão & Conteúdo \\
\hline Significante & Significado \\
\hline Som & Designatum \\
\hline
\end{tabular}

Quadro 10 - Forma e Substância 


\section{E) Paradigma e Sintagma}

LOPES (1987, p.88) afirma que

"A dependência que existe entre dois elementos seqüenciais de uma mesma cadeia chama-se relação (dependência, função) sintagmática (de sintagma: conjugado de duas unidades consecutivas onde o valor de cada uma se define por relação ao valor da outra)".

Em outro trabalho, o autor complementa (idem, p.108):

"A cadeia significante se constrói pela combinação seqüencial de dois elementos sucessivos que contrastam funcionalmente entre si (como subordinante/subordinado, na ordem sintática; como determinante/determinado, na ordem semântica) na qualidade de elementos in praesentia, efetivamente realizados no enunciado: são esses elementos sucessivos, explicitados e contrastantes na cadeia que constituem o eixo sintagmático da parole".

Para o autor (idem, p.90), “o sintagma se constrói com base na contigüidade e na irreversibilidade: seus elementos estão dotados de uma distribuição característica, funcional”.

Assim, LOPES (idem, p.89) afirma que "o discurso sintagmático dispõe-se sobre um eixo cujo suporte segmental é a extensão linear dos significantes e cuja propriedade básica é a construir-se através de combinação de unidades contrastantes".

Os signos, dentro do sistema, estabelecem relações de identidade e diferença com os outros signos. Quando se trata da relação de substituição virtual entre os signos temos a relação paradigmática. Ao se optar por um signo, dispensa-se o uso de todos os outros possíveis. Quando se trata da combinação entre signos, em uma cadeia ou frase, temos a relação sintagmática, uma relação de coexistência entre signos (TÁLAMO, 1997, p.7). 
O eixo paradigmático é o "eixo das substituições e comutações possíveis empregado para a formulação das macro-estruturas conceituais", e o eixo sintagmático é o "eixo das associações e combinações realizadas, empregado para a formação da gramática enunciativa" (GARCÍA GUTIÉRREZ, 1998, p.12).

HUTCHINS ressalta que no eixo paradigmático a organização é determinada pelo compartilhamento de características dos elementos, o que permite sua substituição, um pelo outro. Já a combinação de elementos ocorre no eixo sintagmático. Para o autor:

"Pode-se olhar o eixo paradigmático como analítico e o eixo sintagmático como sintético. As relações paradigmáticas são 'fixadas' pela estrutura do sistema lingüístico, enquanto as sintagmáticas são 'selecionadas' durante a enunciação de mensagens particulares - a primeira, a priori, enquanto a última, a posteriori" (HUTCHINS, 1975, p.6).

Portanto, se é a relação que oferece significação, a proposição de sintagmas nos parece fundamental para uma Linguagem Documentária.

Assim, resumidamente, temos as seguintes características:

\begin{tabular}{|l|l|}
\hline \multicolumn{1}{|c|}{ Paradigma (associação) } & \multicolumn{1}{c|}{ Sintagma (combinação) } \\
\hline Escolhas & Regras gramaticais \\
\hline Língua & Fala \\
\hline Possibilidades & Seqüência \\
\hline $\begin{array}{l}\text { Correlação - função ou dependência } \\
\text { entre os termos }\end{array}$ & $\begin{array}{l}\text { Relação - função existente entre os } \\
\text { constituintes }\end{array}$ \\
\hline Oposição & Contraste \\
\hline
\end{tabular}




\title{
3.4. A introdução do sujeito na teoria estrutural
}

O programa estruturalista não incluía explicitamente o sujeito, o que foi inaugurado pela introdução da questão da enunciação. "A lingüística só tem acesso ao estágio de ciência, para Saussure, na condição de delimitar muito bem o seu objeto específico: a língua; e deve, portanto, desembaraçar-se dos resíduos da fala, do sujeito, da psicologia" (DOSSE, 1993, p.73). Saussure (p.30, citado por DOSSE, 1993, p.73), afirma que

\begin{abstract}
"a língua não constitui, pois, uma função do falante: é o produto que o indivíduo registra passivamente /.../. A língua, distinta da fala, é um objeto que se pode estudar separadamente. Não falamos mais as línguas mortas, mas podemos perfeitamente assimilar-lhes 0 organismo lingüístico".
\end{abstract}

No entanto, BENVENISTE e seus seguidores, entre os quais DUCROT, viram na enunciação um fator importante para o desenvolvimento dos estudos lingüísticos. Dessa forma, o sujeito passou a ser integrado na lingüística (DOSSE, 1994, p.25).

Isso porque, como afirma CINTRA, "os métodos estruturais, excessivamente presos à uma visão positivista de só operar com dados, não permitia a formulação de questões perturbadoras, como as que se faziam sobre a criatividade da linguagem (1983, p.18). Este pensamento levou em consideração os estudos de Chomsky que "desdobra a criatividade em dois tipos, que classifica sucessivamente de criatividade que muda as regras e de criatividade governada pelas regras. $O$ primeiro tipo depende do desempenho e o segundo da competência da língua" (DOSSE, 1994, p.25).

Chomsky deu início à vertente lingüística denominada gerativismo ou gerativotransformacional, que se seguiu ao apogeu do estruturalismo nos anos 60, a partir da "progressão de uma lingüística da enunciação que tinha sido até então rechaçada" 
(DOSSE,1994, p.61). Chomsky e sua teoria buscam "um conjunto finito de regras que responda pela produção dos enunciados, ou dito de outra forma, é um conjunto de regras que faculta ligar o sentido à forma pela qual os enunciados se expressam" (CINTRA, 1983, p.19).

Após a revolução de maio de 68 na França' afirma DOSSE que ocorre o "nascimento e desenvolvimento espetacular de uma "sociolingüística", que permite reintroduzir o referente no campo de estudo da lingüística" (idem, p.143). Para o autor (idem, p.159):

"Tudo o que importunava interiormente o estruturalismo antes de 1968 para the assegurar o desenvolvimento, seja o gerativismo, as teorias da enunciação, a intertextualidade, a crítica do logocentrismo: é o triunfo de tudo isso que maio de 68 assegura, ao acelerar o processo de extravasamento a que Manfred Frank chamou de o "neoestruturalismo".

BENVENISTE $^{13}$ (1985, p.45, citado por DOSSE, 1994, p.222) afirma à época - 1969 que "é preciso que todo signo seja inserido e compreendido num sistema de signos. Aí está a condição da significância". Passa a considerar, então, as diversas situações interlocutivas.

É somente nos anos oitenta, entretanto, que a teoria da enunciação de BENVENISTE ganha impulso. "Ela devolve ao sujeito um lugar destacado na reflexão lingüística" (DOSSE, 1994, p.364).

De acordo com ORLANDI, "Os recortes e exclusões feitos por Saussure e por Chomsky deixam de lado a situação real de uso (a fala, em um, e o desempenho, no

\footnotetext{
${ }^{13}$ BENVENISTE, E. Sémiologie de la langue. Mouton, 1969, reproduzido em Problèmes de linguistique general, v2, 1985.
} 
outro) para ficar com o que é virtual e abstrato (a língua e a competência)" (2003, p.48). Para a autora, é através da pragmática "que se inclui, ao lado da relação entre signos (sintaxe) e do estudo das relações entre os signos e o mundo (semântica), o estudo das relações entre os signos e seus usuários” (idem, p.55)

Sobre as pesquisas em pragmática, BARANOW (1983, p.27) comenta que:

"Nessas novas áreas de pesquisa que se vêm delineando na Lingüística, a linguagem é analisada no seu contexto comunicativo ou seja, numa dimensão funcional. Retoma-se com isto uma tradição da Lingüística européia de uma temática, que as escolas estruturalistas e pós-estruturalistas americanas (com algumas exceções) haviam deixado de lado".

O autor prossegue afirmando que "as preocupações dos lingüistas com os aspectos pragmáticos da linguagem nasceram da constatação de que a comunicação em linguagem natural depende de condições que vão além da linguagem propriamente dita" (BARANOW, 1983, p.28).

Atualmente, e desde de os anos sessenta, pode-se falar no início de um pósestruturalismo, que de acordo com PETERS (2000), seria uma resposta ao estruturalismo de Lévi-Strauss na antropologia, Althusser no marxismo, Lacan na psicanálise, e de Barthes na literatura. O pós-estruturalismo é representado por diversos pensadores, entre outros, Derrida, Kristeva, Bathes, Deleuze, Guattari, Foucault e Baudrillard. Seus estudos atingem diversos campos do conhecimento, tal como fazia o estruturalismo (HARLAND, 1987, p.1-3). Para PETERS (2000):

"Os pensadores pós-estruturalistas desenvolveram formas peculiares e originais de análise (gramatologia, desconstrução, arqueologia, genealogia, semioanálise), com freqüência dirigidas para a crítica de instituições específicas (como a família, o Estado, a prisão, a clínica, 
a escola, a fábrica, as forças armadas, a universidade e até mesmo a própria filosofia) e para a teorização de uma ampla gama de diferentes meios (a "leitura", a "escrita", o ensino, a televisão, as artes visuais, as artes plásticas, o cinema, a comunicação eletrônica)."

Confirma-se, assim, o que configurara o pós-estruturalismo: a inclusão do sujeito, a enunciação, e a participação do indivíduo nos processos de estruturação.

De acordo com HARLAND (1987, p.91):

"O problema dos lingüistas estruturais é que, uma vez que começaram a explicar a linguagem hermeticamente, eles não encontraram motivo para parar. Não há limite claramente visível onde o tipo de explicação deles termine. Então, uma decisão metodológica original de excluir o mundo exterior (explícito em Benveniste e Hjelmslev) gradualmente torna-se um princípio filosófico geral de escopo ilimitado".

O pós-estruturalismo, ao trazer a enunciação e o sujeito para suas análises e discussões, dá ênfase à prática mais do que à linguagem (HARLAND, 1987, p.155).

Para RADFORD e RADFORD (2005, p.61):

"O pós-estruturalismo não apenas questiona, mas também continua o projeto central do estruturalismo - investigação dos princípios de organização de um sistema de linguagem. Entretanto, enquanto o estruturalismo afirma que o sistema de linguagem pode ser descrito de um modo objetivo e científico, o pós-estruturalismo sugere que tais descrições são em si altamente contextuais. Enquanto o estruturalismo de Saussure estava confiante de que os princípios pelos quais a linguagem é organizada podem ser totalmente determinados e descritos, o pós-estruturalismo põe em questão todas essas afirmações e sugere que tais conclusões são sempre frágeis e abertas à subversão".

Assim, os autores afirmam que: 
"O pós-estruturalismo repudia a noção de que existam verdades duradouras que podem ser invocadas com certeza no processo de significação. Todas as verdades são totalmente contextuais e o resultado da relação entre signos incluindo as principais proposições do estruturalismo! Essas proposições não podem ser consideradas verdadeiras ou falsas. Elas apenas podem vir a "fazer sentido" no contexto de outras proposições e signos" (RADFORD e RADFORD, 2005, p.69).

Para DUCROT (1968, p.60-112, citado por PAVEAU e SARFATI, 2006 p.90), é possível falar em três etapas fundamentais sobre a apreensão do conceito de estrutura. As duas primeiras desembocam no estruturalismo e a terceira etapa, ao considerar desenvolvimentos mais recentes da lingüística como a teoria da enunciação e a pragmática, remetem ao pós-estruturalismo. A primeira etapa consiste no reconhecimento de cada língua tem uma organização que lhe é própria e que não remete ao seu exterior. A segunda etapa, com Saussure, traz a essa organização uma realidade, entendendo-se a língua como um instrumento de comunicação, um sistema arbitrário. Por fim, a terceira etapa considera que a organização depende da distribuição dos papéis no jogo social, ou seja, leva em conta o contexto e as relações intersubjetivas do diálogo.

Identificando tais etapas, DUCROT enfatiza a transformação da idéia de estrutura. Tal noção foi primeiramente utilizada para estudar a língua como uma organização de elementos e, com a introdução dos estudos de enunciação, vê-se a idéia da estruturação como um processo contínuo que solicita a participação dos indivíduos que usam a língua. Como afirma DUCROT, "a combinatória semântica é constantemente explorada pelos sujeitos falantes para organizar as relações intersubjetivas no diálogo. (...) Sua estrutura manifestar-se-ia, então, como uma nova distribuição dos papéis no jogo social" (DUCROT, citado por PAVEAU e SARFATI, 2006, p.90). Isso quer dizer que se deve conjugar a idéia de estrutura com a do processo de estruturação na qual os usuários da língua têm participação efetiva. 
A consideração dos elementos pragmáticos (enunciação, situação de uso), não descarta, portanto, a noção da importância das relações estruturais, mas conjuga-a aos processos efetivos de uso da linguagem.

Essa perspectiva deverá balizar a análise das Linguagens Documentárias a ser realizada mais à frente, quando nos referiremos à noção de estrutura, mas também ao processo que prevê a participação dos sujeitos na enunciação dos discursos.

\subsection{Apropriação da Lingüística pela Documentação}

\subsubsection{O termo linguagem na Documentação}

A Documentação é uma disciplina que se propõe a tratar a informação para fins de recuperação - garantir o acesso do usuário aos conteúdos informacionais no menor tempo e custo possíveis, transformando estoques em fluxos informacionais. A Documentação reconhece que as Linguagens Documentárias utilizam os parâmetros lingüísticos para sua elaboração. Como se afirmou anteriormente, no interior do campo da Documentação/Ciência da Informação, desenvolveu-se, a partir das contribuições européias, o sub-campo da Lingüística Documentária, que observa mais detalhadamente o processo de natureza lingüística envolvido no tratamento da informação.

Para GARCÍA GUTIÉRREZ (1990, p.76), o termo "linguagem" era utilizado para "denominar instrumento classificatórios desprovidos de essência lingüística". Isso só foi mudar com o aparecimento das linguagens combinatórias que despertaram um interesse pela lingüística.

De acordo com GARCÍA GUTIÉRREZ (1998, p.16): 
"As linguagens documentárias, como a dramaturgia neoclássica, os contos russos, os textos científicos ou as notícias ajustam-se a superestruturas que regem, desde o maior nível de abstração, os comportamentos do conjunto de termos, regras e operadores no nível da superfície as interações entre esses elementos. Os cânones estruturais permitem reconhecer as linguagens e construi-las".

A Lingüística Documentária reconhece a natureza simbólica da comunicação documentária e afirma a necessidade de composição de quadros de referência para a análise, avaliação e construção dessa modalidade de linguagem construída (TÁLAMO, 2001, p.142).

Da Lingüística Estruturalista, a Lingüística Documentária utiliza vários conceitos para o desenvolvimento das Linguagens Documentárias. Antes mesmo da proposta do subcampo específico da Lingüística Documentária, GARDIN, atento às contribuições da Lingüística para os desenvolvimentos das Linguagens Documentárias, busca entender e aplicá-las de maneira a otimizar seu papel na organização, recuperação e transferência de informações (GARDIN,1973). Isso pode ser visto em seus trabalhos desde a década de sessenta $(1966,1968)$ e com mais evidência em seu artigo sobre Lingüística e Documentação (1973).

A comunicação da informação só é possível através de uma linguagem em que haja significação para os envolvidos. Dar acesso à informação e promover sua circulação são ações que fazem necessário o uso de uma linguagem que a represente baseada em uma hipótese de organização que permita a construção de significação - a Linguagem Documentária. Dessa forma, a elaboração dessa linguagem requer metodologias que tenham como referência conceitos lingüísticos e também terminológicos. 
Como lembra GARCÍA GUTIÉRREZ, (1990, p.11), “os métodos de descrição da língua são úteis para a formulação de modelos de construção de linguagens documentárias".

Já em 1966, GARDIN elaborou um modelo para o entendimento dos léxicos documentários e das classificações em geral. Para ele, os léxicos documentários apresentam grande variedade de formas: glossários, tesauros, listas de palavraschave, códigos semânticos, classificações, etc. (1966, p.172). Para o autor, um léxico documentário do tipo classificação seria "todo conjunto organizado de termos destinados à indexação documentária, qualquer que seja o procedimento utilizado para expressar a organização em questão" (idem).

GARDIN propõe, conforme a figura a seguir, uma tipologia geral de léxicos documentários (1966, p.173-77). Com essa tipologia, GARDIN passa a caracterizar esses léxicos de acordo com reconhecimento de traços de linguagem natural e linguagem construída para fins documentários. Isto possibilita comparar a influência da lingüística na elaboração desses instrumentos: 


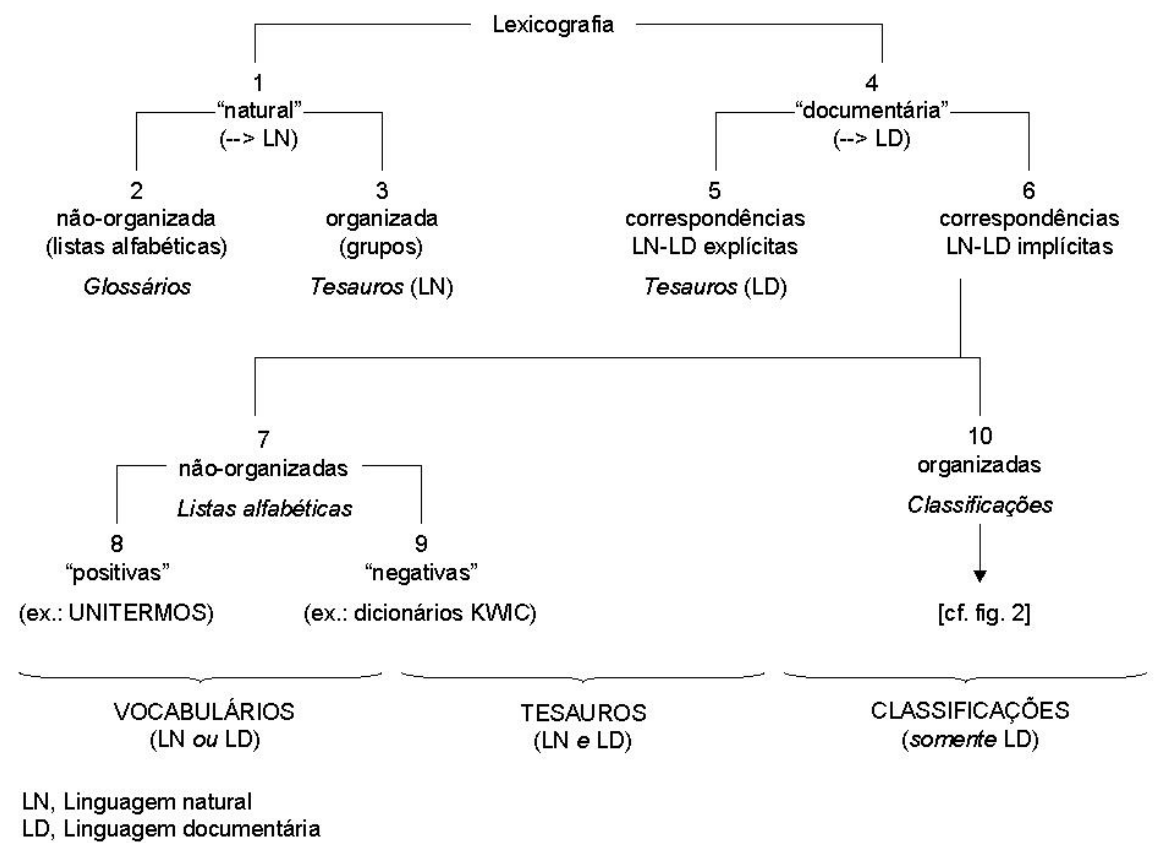

Figura 1 - GARDIN, 1966 p.174.

O autor compreende os tipos acima conforme segue:

1. Lexicografia natural: visa somente observar certos fatos relacionados com as ocorrências de palavras em uma dada língua, através de um corpus particular.

2. Glossários: todo conjunto de termos naturais presentes em uma ordem nãosignificante. Pode conter definições, mas não relações entre os termos;

3. Tesauros LN: conjunto de termos naturais em ordem significante (semântica). Pode conter definições;

4. Lexicografia documentária: listas finitas de termos, que servem à formulação de representações indexadas, mais curtas e estereotipadas que as expressões naturais correspondentes;

5. Tesauros LD: tipo de dicionário bilíngüe (ou multilíngüe) com termos ou expressões de uma ou mais linguagens naturais e sem equivalentes canônicos do léxico documentário adotado; 
6. Léxico documentário com correspondências explícitas: não apresenta as formas em LN;

7. Listas Alfabéticas: listas de termos naturais, não de todo o vocabulário do domínio, mas de uma seleção dele;

8. Positivas: listas de palavras ou termos dignos de serem retidos no enunciado natural de um documento, para representar seu conteúdo;

9. Negativas: listas de termos excluídos, que servem para controlar a extração no enunciado;

10. Classificações: listas positivas de palavras-chave em ordem alfabética acompanhadas de remissivas.

$\mathrm{Na}$ seqüência, GARDIN organiza as classificações de acordo com seus traços estruturais, isto é, segundo o número de relações analíticas (1966, p.177-81). Estrutura pressupõe um princípio de ordem, uma organização, de acordo com critérios determinados, pontos de vista sobre a realidade. Ao reconhecer que as classificações são léxicos organizados, GARDIN também reconhece que tais léxicos possuem uma estrutura que pode ser entendida do ponto de vista lingüístico: 


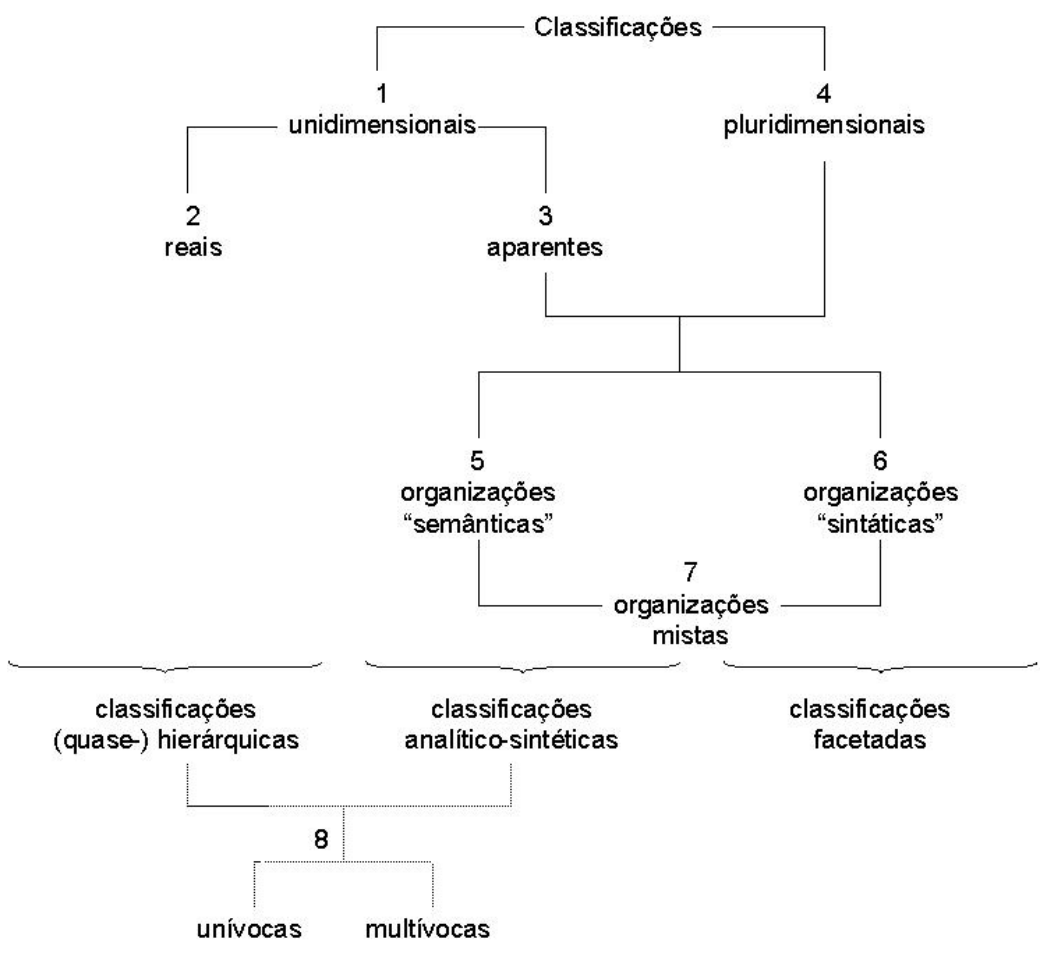

Figura 2 - GARDIN, 1966, p.178

Tais classificações são definidas conforme segue:

1. Unidimensionais: têm apenas um tipo de relação analítica;

2. Unidimensionais reais: classificações onde a relação constitutiva é efetivamente única, em todos os níveis e para todos os grupos da classificação;

3. Unidimensionais aparentes: apresentam mais de um tipo de relação analítica, mas afirmam ter apenas um;

4. Pluridimensionais: onde cada termo pode ser relacionado a várias classes, em virtude de diferentes dimensões;

5. Pluridimensionais semânticas: ordem de termos que seja o reflexo de um conjunto de definições admitidas, em um dado grupo humano;

6. Pluridimensionais sintáticas: uma ordem de termos fundada não mais sobre a essência das entidades que eles designam, mas sobre sua função particular, em um campo determinado de observação [facetas]; 
7. Mistas: onde pontos de vista essenciais e funcionais são alternados como combinados. São as classificações analítico-semânticas;

8. Unívocas X Multívocas: Unívocas, onde um termo ocupa um e somente um lugar, e multívocas, onde há repetições.

A proposta da lexicografia documentária acima põe em destaque relações estruturais: primeiro, na comparação entre os vários tipos de léxicos, observando não só as diferenças entre eles, como as correspondências que apresentam em relação à linguagem natural; segundo, na abordagem das dimensões das relações no interior de cada léxico, relações essas que se distribuem segundo o número de vértices a partir dos quais são feitas as conjunções e disjunções, como outras associações.

Pode-se afirmar que, mesmo sem mencionar o termo estrutura na análise dos léxicos feita por GARDIN, a tipologia proposta e a abordagem sobre o grau de complexidade das relações que apresentam os variados tipos, revela o princípio básico estrutural.

GARDIN, portanto, reconhece que as características lingüísticas fazem parte das Linguagens Documentárias. De modo concreto, a noção é utilizada quando ele coordena um grupo de pesquisa para o desenvolvimento de uma Linguagem Documentária que contemple os parâmetros lingüísticos. Trata-se do SYNTOL (Syntagmatic Organization Language), que será discutido mais adiante. A análise dos léxicos e a proposta de sua tipologia já enunciam, de fato, a possibilidade do uso formal dos princípios lingüísticos. Note-se, todavia, que o autor não via na Lingüística de sua época uma referência explícita para a Documentação, preferindo falar da Lógica (LARA, 1999). Reconhece-se, no entanto, que tais parâmetros sempre estiveram na base de sua proposta. 


\subsubsection{Linguagem Natural versus Linguagem Documentária}

As Linguagens Documentárias foram construídas tendo como base a linguagem natural. De forma mais, ou menos, explícita, esse princípio subjaz a todas elas.

Há grandes diferenças, entretanto, entre a linguagem natural e a Linguagem Documentária, como também semelhanças.

A linguagem natural é um sistema de relações virtuais, uma linguagem articulada. Seu uso não pressupõe o conhecimento explícito das regras que a comandam na sua utilização.

A Linguagem Documentária, por seu lado, é um sistema de relações construído, organizado segundo uma hipótese sobre um universo temático selecionado, ou seja, adota um arranjo que privilegia determinados aspectos em detrimento de outros, representando uma escolha, uma opção.

O conhecimento de suas regras é obrigatório, e sua significação ocorre de acordo com as definições dadas a seus elementos que se articulam pelo modo de relacionamento entre os termos. É uma linguagem intermediária, que apresenta características e termos da linguagem natural e da linguagem de especialidade do campo que se propõe a traduzir, representar.

Quando optamos pela utilização de uma Linguagem Documentária para representação das informações de um sistema, desejamos, entre outras coisas, reduzir a redundância, as ambigüidades, polissemias, variações de seus elementos, ou seja, buscamos univocidade interpretativa via controle do vocabulário: escolhemos quais termos serão as unidades preferenciais, explicitamos ou indicamos a correspondência unidades/conceitos, e procuramos controlar a sinonímia. Dessa forma, também 
estabelecemos um controle sobre a significação, como um modo de orientar a busca de informações.

Por ter como objetivo a comunicação, a Linguagem Documentária é construída sob forma de linguagem. No entanto, não basta uma estrutura e relações para que a Linguagem Documentária seja bem sucedida; é preciso que, durante sua elaboração, seja estabelecido um princípio de classificação que se desenha de acordo com os usuários e área do conhecimento ou atividade selecionada. Do mesmo modo, é necessário que se considere os objetivos da instituição ou comunidade que fará uso dessa Linguagem Documentária. A elaboração deve levar em conta os conceitos utilizados nesse âmbito. Ao contrário da linguagem natural, a Linguagem Documentária propõe economia de vocabulário de modo a concentrar a busca e limitar a atribuição de significados a um significante. Como uma via de acesso, uma Linguagem Documentária deve propor vários pontos para entrada no sistema de informações, isto é, repertoriar as diversas formas de expressão utilizadas por uma comunidade, identificando sinônimos e quase-sinônimos existentes para um mesmo termo dentro de uma área determinada.

Observe-se que diferentemente do que ocorre com a linguagem natural, a função comunicativa das Linguagens Documentárias "é restrita a contextos documentários, ou seja, as LDs devem tornar possível a interação usuário-sistema" (CINTRA e outras, 2002, p.34).

HUTCHINS compara o processo comunicacional da linguagem natural e das Linguagens Documentárias da seguinte forma (HUTCHINS, 1975, p.3-4): 


\begin{tabular}{|l|l|l|}
\hline \multicolumn{1}{|c|}{ Elementos } & \multicolumn{1}{c|}{ LN } & \multicolumn{1}{c|}{ LD } \\
\hline Signo & Sons físicos ou escritos & Formas físicas da LD \\
\hline Intérpretes & Falantes e ouvintes & Indexadores e usuários \\
\hline Designata & $\begin{array}{l}\text { Relações entre as formas } \\
\text { físicas dos signos e os } \\
\text { objetos físicos a que se } \\
\text { referem }\end{array}$ & $\begin{array}{l}\text { Relações entre as formas } \\
\text { físicas dos signos da LD e } \\
\text { seu conteúdo informacional }\end{array}$ \\
\hline Referentes & Objetos físicos & Conteúdo informacional \\
\hline Efeitos & Mudanças nos intérpretes & Reações dos usuários \\
\hline Contextos & $\begin{array}{l}\text { Ambientes textuais e } \\
\text { situacionais }\end{array}$ & $\begin{array}{l}\text { Organização física do } \\
\text { índice e o ambiente geral } \\
\text { do centro de informações }\end{array}$ \\
\hline
\end{tabular}

Quadro 12 - Comparação entre Linguagem Natural e Linguagem Documentária

Para HUTCHINS, outra diferença entre linguagem natural e Linguagem Documentária se dá em relação à finalidade e às funções que devem desempenhar. Enquanto a linguagem natural pode ter função descritiva ou factual, conativa, valorativa, prescritiva, expressiva, evocativa ou estética, fática ou social, e de metalinguagem, a Linguagem Documentária apresenta apenas função descritiva. Enquanto a linguagem natural serve para diversos fins, a Linguagem Documentária é construída para um fim específico (1975, p.8).

No contexto das Linguagens Documentárias, encontram-se algumas funções específicas, sendo a função de comunicação entre leitores e documentos a principal. No eixo sintagmático, pode-se falar em função de indexação e função de busca, que variam conforme os recursos combinatórios; no eixo paradigmático existem funções adicionais como a de guiar indexadores na escolha de descritores para os documentos, e a de guiar usuários na seleção de descritores para a busca. Na construção de uma Linguagem Documentária, deve-se estabelecer como e em que nível serão desempenhas tais funções, para que sua estrutura seja clara, uma vez que esta é a condição necessária para que se descreva como funciona a linguagem. Portanto, estrutura e função são interdependentes (HUTCHINS, 1975, p10-11). 
Podemos estabelecer dois níveis para diferenciação entre linguagem natural e Linguagem Documentária: o nível formal e o nível semântico. No nível formal da linguagem natural, as formas escritas são secundárias em relação às formas vocais e normalmente derivadas delas. Nas Linguagens Documentárias, as formas escritas são básicas, e correspondem aos sintagmas de símbolos notacionais, como números, letras, pontuação. No nível semântico, a ocorrência de sinonímia e homonímia demonstra não existir correspondência um a um entre suas palavras. Nas Linguagens Documentárias, temos os descritores ou sintagmas de componentes semânticos, que buscam a univocidade (HUTCHINS, 1975).

Para LARA (2006, p.24) a linguagem natural "é, por excelência, o lugar dos jogos interpretativos que se desenvolvem através de cadeias e associações de interpretantes". Já nas linguagens artificiais há a remissão "via sua simbologia, a significados unívocos que, paradoxalmente, dependem, na comunicação, do conhecimento de regras próprias e explícitas" (idem, p.24) A Linguagem Documentária estaria num nível intermediário entre a linguagem natural e a linguagem artificial, não apenas por "funcionar como ponte entre sistema documentário e usuário, mas porque conjuga elementos de ambos os tipos de linguagem, constituindo uma terceira de natureza complexa", ora remetendo à linguagem natural, ora à linguagem artificial (idem, p.24). Além disso:

"Os três tipos de linguagem também diferem quanto aos seus objetivos: a LA e a LD desempenham principalmente as funções informativa, ou referencial, e a função prescritiva; a LN não tem função específica e funciona em distintos contextos. Nela, a função referencial ou informativa é a menos importante" (LARA, 2006, p.25). 
LARA, a partir de diferentes fontes, propõe sistematizar as principais semelhanças e diferenças entre linguagem natural, a Linguagem Documentária e a linguagem artificial, formulando o quadro adiante:

a) Diferenças Principais

\begin{tabular}{|c|c|c|}
\hline Linguagem Natural & Linguagem Artificial & Linguagem Documentária \\
\hline $\begin{array}{l}\text { Formas escritas } \\
\text { secundárias em relação às } \\
\text { formas orais }\end{array}$ & $\begin{array}{l}\text { Formas escritas } \\
\text { fundamentais }\end{array}$ & $\begin{array}{l}\text { Formas escritas } \\
\text { fundamentais }\end{array}$ \\
\hline $\begin{array}{l}\text { Os lexemas [palavras] não } \\
\text { têm significação unívoca }\end{array}$ & $\begin{array}{l}\text { Os significados são } \\
\text { altamente padronizados. } \\
\text { Univocidade de significação. }\end{array}$ & $\begin{array}{l}\text { Os significados devem ser } \\
\text { fixados, mas o uso de } \\
\text { palavras da LN impede a } \\
\text { univocidade de } \\
\text { interpretação. }\end{array}$ \\
\hline Dinâmica & Estáticas & Estáticas \\
\hline $\begin{array}{l}\text { Usa-se a língua para falar } \\
\text { dela mesma. }\end{array}$ & $\begin{array}{l}\text { Necessário usar a LN para } \\
\text { falar da LA. }\end{array}$ & $\begin{array}{l}\text { Necessário usar a LN para } \\
\text { falar da LD. }\end{array}$ \\
\hline $\begin{array}{l}\text { Tem regras de fato. Não é } \\
\text { necessário conhecer as } \\
\text { regras da língua para usa- } \\
\text { la. }\end{array}$ & $\begin{array}{l}\text { Tem regras de jure. } \\
\text { Fundamental obedecer às } \\
\text { regras. Linguagem } \\
\text { altamente simbólica. }\end{array}$ & $\begin{array}{l}\text { Tem regras de jure. } \\
\text { Fundamental obedecer às } \\
\text { regras, embora reconheça- } \\
\text { se, nas LDs, as palavras, a } \\
\text { partir de suas semelhanças } \\
\text { com àquelas das LN. }\end{array}$ \\
\hline $\begin{array}{l}\text { Não tem uma função } \\
\text { específica, mas funciona em } \\
\text { muitos contextos e para } \\
\text { diferentes objetivos. }\end{array}$ & $\begin{array}{l}\text { Elaborada para } \\
\text { desempenhar funções } \\
\text { específicas. }\end{array}$ & $\begin{array}{l}\text { Elaborada para } \\
\text { desempenhar uma função } \\
\text { particular: representar e } \\
\text { transferir informação. }\end{array}$ \\
\hline $\begin{array}{l}\text { Tem inúmeras funções: } \\
\text { função expressiva } \\
\text { (estética), descritiva } \\
\text { (informativa, referencial), } \\
\text { valorativa, prescritiva. }\end{array}$ & $\begin{array}{l}\text { Desempenha } \\
\text { principalmente a função } \\
\text { descritiva (informativa, } \\
\text { referencial) e a função } \\
\text { prescritiva. }\end{array}$ & $\begin{array}{l}\text { Desempenha principalmente } \\
\text { a função descritiva } \\
\text { (informativa, referencial) e a } \\
\text { função prescritiva. }\end{array}$ \\
\hline Tem produtividade. & Não tem produtividade. & Não tem produtividade. \\
\hline Pouco formalizada. & Altamente formalizada. & Relativamente formalizada. \\
\hline Alto poder combinatório. & Médio poder combinatório & Baixo poder combinatório. \\
\hline
\end{tabular}

FONTE: LARA, 2000. Quadro comparativo LN, LA, LD, com base em CINTRA, 1983;

HUTCHINS, 1975. 
b) Semelhanças

\begin{tabular}{|l|l|l|}
\hline \multicolumn{1}{|c|}{ Linguagem Natural } & \multicolumn{1}{c|}{ Linguagem Artificial } & Linguagem Documentária \\
\hline $\begin{array}{l}\text { Lexemas têm forma e } \\
\text { significado. }\end{array}$ & $\begin{array}{l}\text { Símbolos têm forma e } \\
\text { significado. }\end{array}$ & $\begin{array}{l}\text { Descritores têm forma e } \\
\text { significado. }\end{array}$ \\
\hline $\begin{array}{l}\text { Estrutura paradigmática e } \\
\text { sintagmática }\end{array}$ & $\begin{array}{l}\text { Estrutura paradigmática e } \\
\text { sintagmática }\end{array}$ & $\begin{array}{l}\text { Estrutura paradigmática e } \\
\text { sintagmática }\end{array}$ \\
\hline
\end{tabular}

Quadro 14 - Semelhanças entre Linguagens Natural, Documentária e Artificial

FONTE: LARA, 2000. Quadro comparativo LN, LA, LD, com base em CINTRA, 1983; e HUTCHINS, 1975

NAVARRO propôs o seguinte quadro:

\begin{tabular}{|c|c|}
\hline Linguagem Natural & Linguagem Documentária \\
\hline São gerais & São especializadas \\
\hline $\begin{array}{l}\text { São estabelecidas e adaptadas através de } \\
\text { longos períodos de tempo e por milhares } \\
\text { de pessoas }\end{array}$ & $\begin{array}{l}\text { São estabelecidas em poucos anos por } \\
\text { um número reduzido de pessoas }\end{array}$ \\
\hline $\begin{array}{l}\text { São naturalmente aceitas e adquiridas } \\
\text { pelos usuários }\end{array}$ & Devem ser aceitas pelos usuários \\
\hline São naturais & São artificiais \\
\hline Têm sua própria estrutura & $\begin{array}{l}\text { Sua estrutura baseia-se na estrutura da } \\
\text { linguagem natural sobre a qual elas são } \\
\text { formadas }\end{array}$ \\
\hline $\begin{array}{l}\text { São menos eficientes que as Linguagens } \\
\text { Documentárias nas operações de } \\
\text { recuperação de informação }\end{array}$ & $\begin{array}{l}\text { São mais eficientes que a linguagem } \\
\text { natural nas operações de recuperação de } \\
\text { informação }\end{array}$ \\
\hline São sensíveis a mudanças culturais & São sensíveis a mudanças culturais \\
\hline Caracterizam-se pela dupla articulação & $\begin{array}{l}\text { Não abrangem o conceito de dupla } \\
\text { articulação }\end{array}$ \\
\hline Têm sua própria teoria & $\begin{array}{l}\text { Baseiam-se na teoria das ciências, da } \\
\text { ciência da informação e da lingüística }\end{array}$ \\
\hline $\begin{array}{l}\text { Compreendem a noção de morfema e } \\
\text { lexema }\end{array}$ & Compreendem a noção de informema \\
\hline $\begin{array}{l}\text { Não têm funções específicas [podem ter } \\
\text { várias] }\end{array}$ & $\begin{array}{l}\text { Têm um propósito específico e um nível } \\
\text { de funções }\end{array}$ \\
\hline $\begin{array}{l}\text { Necessitam respeitar uma hierarquia de } \\
\text { traços para evitar malformações } \\
\text { gramaticais ou atenuá-las }\end{array}$ & $\begin{array}{l}\text { Necessitam de hierarquias semânticas e } \\
\text { sintáticas para evitar malformações }\end{array}$ \\
\hline $\begin{array}{l}\text { As funções conativa, emotiva, fática e } \\
\text { poética (entre outras já mencionadas) são } \\
\text { próprias da linguagem natural }\end{array}$ & $\begin{array}{l}\text { Não são dotadas das funções conativa } \\
\text { (imperativa), emotiva (interjeição), fática } \\
\text { (mensagem que serve para estabelecer, } \\
\text { prolongar ou interromper a comunicação) } \\
\text { e poética }\end{array}$ \\
\hline $\begin{array}{l}\text { Os monemas autônomos e funcionais } \\
\text { assim como as modalidades, são } \\
\text { elementos da linguagem natural }\end{array}$ & $\begin{array}{l}\text { Não comportam pronomes nem } \\
\text { modalidades como o artigo, o número, o } \\
\text { tempo e pessoa nem categorias como o } \\
\text { advérbio e adjetivos }\end{array}$ \\
\hline
\end{tabular}

Quadro 14 - Comparação entre Linguagem Natural e Linguagem Documentária. FONTE: NAVARRO, 1998, p.54-55. 
Como se vê, é possível identificar na construção das Linguagens Documentárias inúmeros conceitos lingüísticos estruturalistas.

CINTRA (1983, p.7) afirma que a Linguagem Documentária é uma linguagem "exatamente porque concretiza a capacidade simbólica do homem, através da organização de seus termos e regras em sistema próprio”.

Para GARCÍA GUTIÉRREZ, a aplicação do método estruturalista serve para criar uma "estrutura de representação e síntese de uma área determinada do conhecimento" (1990, p.35). Dessa forma, “a linguagem documentária, segundo o método estruturalista, é um sistema organizado de elementos dotados de significação determinada pelas relações que mantêm entre eles baseadas na oposição. (...) e o principal condicionante do significado é o uso" (idem). Para o autor:

"Em uma LD deve haver mais significados referenciados que significantes em presença, quer dizer, deve-se tender à construção de todos os conteúdos possíveis a partir de uns poucos termos em combinação potencial (...) Esta nova concepção das LD faz necessária a sintaxe, o contexto permanente e a redistribuição do conteúdo das facetas nas LD clássicas: não somente os traços significativos ou substantivos participam na faceta, mas também os sentido, os valores e as perspectivas" (idem, p.137).

Para LARA, “a noção fundamental para a construção de uma linguagem documentária é a de estrutura lingüística” (LARA, 1999, p.60). A partir daí, a autora sugere que algumas categorias teóricas do estruturalismo sejam assimiladas pela Documentação, como parâmetros para organização das Linguagens Documentárias (idem, p.63-66).: 


\begin{tabular}{|l|l|l|}
\hline \multicolumn{1}{|c|}{ Categorias } & \multicolumn{1}{|c|}{ Lingüística } & \multicolumn{1}{c|}{ LD } \\
\hline Relatividade & $\begin{array}{l}\text { Identidade e diferença, } \\
\text { nenhum elemento existe } \\
\text { sozinho numa mensagem }\end{array}$ & $\begin{array}{l}\text { Rede de relações segundo } \\
\text { uma hipótese de } \\
\text { organização, propósitos; } \\
\text { significado dado pela } \\
\text { organização interna da LD }\end{array}$ \\
\hline Funcionalidade & $\begin{array}{l}\text { Utilidade local de um } \\
\text { elemento dentro de um } \\
\text { conjunto; a noção de } \\
\text { função se identifica à noção } \\
\text { de estrutura }\end{array}$ & $\begin{array}{l}\text { Significado de um termo via } \\
\text { rede estrutural de relações }\end{array}$ \\
\hline Unidade & $\begin{array}{l}\text { Estrutura como universo } \\
\text { constituído de partes } \\
\text { constituintes } \\
\text { complementares }\end{array}$ & $\begin{array}{l}\text { Eixo semântico da LD } \\
\text { definido pela oposição } \\
\text { inicial que determina a } \\
\text { leitura }\end{array}$ \\
\hline Totalidade & $\begin{array}{l}\text { Coesão sintática e } \\
\text { semântica }\end{array}$ & $\begin{array}{l}\text { LD como um todo } \\
\text { significante, um sistema de } \\
\text { significação }\end{array}$ \\
\hline Transformabilidade & Estrutura mutante & $\begin{array}{l}\text { Sentido incompleto dos } \\
\text { descritores }\end{array}$ \\
\hline Auto-regulatividade & $\begin{array}{l}\text { Reacomodação interna das } \\
\text { regras }\end{array}$ & $\begin{array}{l}\text { Rearranjo a partir de regras } \\
\text { determinadas }\end{array}$ \\
\hline
\end{tabular}

Quadro 15 - Categorias do Estruturalismo nas Linguagens Documentárias

Para LARA, podemos afirmar que as Linguagens Documentárias constituem um sistema de significação graças à noção de estrutura (idem, p.156).

Na linguagem natural, os signos são considerados arbitrários. De acordo com CINTRA (1983, p.8) "nas linguagens documentárias, os signos são também arbitrários a priori, na medida em que são utilizados significados da linguagem verbal e fixados, ou arbitrados seus significados no sistema construído".

De acordo com a autora (CINTRA, 1983, p.9), os descritores das Linguagens Documentárias correspondem a unidades portadoras de forma e significado. 


\begin{tabular}{|l|l|}
\hline \multicolumn{1}{|c|}{ Linguagem Natural } & \multicolumn{1}{c|}{ Linguagem Documentária } \\
\hline $\begin{array}{l}\text { Cada signo lingüístico se opõe a todos os } \\
\text { outros da língua }\end{array}$ & $\begin{array}{l}\text { Cada signo documentário se opõe a todos } \\
\text { os outros do sistema no qual se inscreve }\end{array}$ \\
\hline $\begin{array}{l}\text { Todo signo está inscrito numa rede } \\
\text { semântica e os trechos mais compactos } \\
\text { forma famílias semânticas }\end{array}$ & $\begin{array}{l}\text { Cada signo está inscrito numa rede } \\
\text { semântica que permite ordenar os termos } \\
\text { em organizações do tipo tesauros }\end{array}$ \\
\hline $\begin{array}{l}\text { Só o contexto permite dominar e precisar } \\
\text { o significado de um signo lingüístico }\end{array}$ & $\begin{array}{l}\text { O significado de cada signo está } \\
\text { previamente delimitado e assume precisão } \\
\text { na relação que estabelece com todos os } \\
\text { outros do sistema }\end{array}$ \\
\hline $\begin{array}{l}\text { Toda troca de vocabulário implica em } \\
\text { troca de semema e esse processo } \\
\text { acarreta alteração na comunicação, pela } \\
\text { perda de alguns semas e/ou pela } \\
\text { introdução de outros }\end{array}$ & $\begin{array}{l}\text { A troca de um termo não necessariamente } \\
\text { implica em alteração no resultado } \\
\text { comunicativo, quer pela utilização de } \\
\text { sinônimos, quer pela inclusão de } \\
\text { antônimos }\end{array}$ \\
\hline
\end{tabular}

Quadro 16 - Signo nas linguagens natural e documentária.

FONTE: CINTRA, 1983, p.14.

Em relação aos signos nas Linguagens Documentárias LARA afirma que os “descritores não são etiquetas, mas o resultado de uma construção julgada pertinente para a significação" (1999, p.66). Assim, funcionam como signos atualizáveis pelos usuários do sistema.

Além disso, a relação significante/significado:

"passa a ser motivada, ou seja, tem uma referência concreta no subcódigo lingüístico relativo ao modelo de especialidade (...) na sua função de representar documentariamente (e de constituir informalmente), o signo documentário reporta-se àquilo que transforma o conceito da área de especialidade em informação" (LARA, 1999, p.67).

Nas Linguagens Documentárias a escrita é fundamental, ao passo que é secundária na linguagem natural (CINTRA, 1983, p.9).

Verifica-se, assim, que a Linguagem Documentária é um sistema normalizado que utiliza a linguagem natural, mas coloca seus elementos em um outro contexto, 
procurando atribuir um significado a somente um significante - visando conferir referência à interpretação dos termos numa área de especialidade. Quando dois ou mais significantes concorrem para o mesmo conceito, eles têm sua distribuição equivalente, e são criadas relações remissivas, fazendo com que se chegue de fato ao conceito desejado. As distribuições de equivalência parcial representam as relações hierárquicas, de termo genérico e termo específico, onde este tem as mesmas características do primeiro, acrescida de uma diferença. A norma tem papel fundamental: dos termos recolhidos da língua, escolhe apenas os pertinentes ao contexto trabalhado, eliminando-se variáveis. Transforma o tesauro em um subcódigo que representa a realidade de uma área (CINTRA e outras, 1994). De fato, é a partir de uma constatação desse tipo que se faz a aproximação à Terminologia, como veremos mais à frente.

Também no campo da Documentação, GREEN (1995, p.366) lembra que: "relações paradigmáticas são baseadas em padrões construídos dentro do sistema da linguagem. (...) Relações sintagmáticas, ao contrário, ocorrem entre elementos lingüísticos de uma forma construída". Para a autora (idem, p.66-7), as relações paradigmáticas formam o esqueleto da estrutura léxica, e as relações sintagmáticas têm uma função comunicativa forte na construção de significado. Porém,

\footnotetext{
"apesar de sua presença constante e da importância de sua função comunicativa, relações sintagmáticas receberam muito menos atenção no desenvolvimento e estudo de linguagens documentárias do que as relações paradigmáticas".
}

GARCÍA GUTIÉRREZ concorda, afirmando que as Linguagens Documentárias "não potenciam a gestão de suas bases léxicas mediante operadores booleanos ou outras gramáticas mais complexas nem desenvolvem satisfatoriamente o eixo sintagmático de seus universos cognitivos, insuficiência que as alija do lingüístico" (GARCíA 
GUTIÉRREZ, 1998, p.13). O autor lembra que o pensamento não se produz por hierarquizações paradigmáticas, e que supõe a sintagmatização (idem, p.34). Assim, "a construção de uma estrutura gramatical", como o eixo sintagmático, "em uma LD é tão importante como a existência da própria LD e uma justificativa imprescindível para a conservação da mesma denominação" (GARCÍA GUTIÉRREZ, 1990, p.38).

O autor afirma que o estabelecimento dos eixos sintagmático e paradigmático é anterior ao estabelecimento das relações (idem, p.87). Para ele:

"As relações paradigmáticas se estabelecem por inclusão, se faz patente a classe ou categoria (lobo implica animal) e por oposição se fazem patente oir ausência (lobo exclui cachorro). As relações sintagmáticas se materializam através da participação (raposa evoca pele) e da associação (raposa evoca astúcia)" (idem, p.92).

Assim, para GARCÍA GUTIÉRREZ (1996, p.28-31) teremos a seguinte situação:

1. Eixo Paradigmático - seleções possíveis: substituição dos sinônimos por termos preferidos.

2. Eixo Sintagmático - seleções realizadas: eliminação de polissemias e substituição por termos mais relevantes

LARA lembra que a precariedade da sintagmatização nas Linguagens Documentárias deve-se à ausência de produtividade, que é característica da linguagem natural, mas não da linguagem construída (LARA, 1999, p.100-106).

Veremos, a seguir, como a Terminologia pode contribuir para o desenvolvimento de Linguagens Documentárias. 


\section{A Terminologia e as Linguagens Documentárias}

A relação da Terminologia com a noção de estrutura e com as Linguagens documentárias diz respeito à possibilidade de operacionalizar a organização sistêmica. A referência às terminologias concretas é, para uma Linguagem Documentária, fundamental para o desenho de sua macro-organização. Já a Terminologia ${ }^{14}$ teóricometodológica dá apoio à organização estrutural das Linguagens Documentárias.

Para introduzir a questão da Terminologia, começaremos por verificar o que ela é e quais são seus princípios fundamentais. Em seguida, procuraremos ressaltar as relações entre a Terminologia e a documentação para verificar como são assimiladas as noções terminológicas, particularmente na elaboração das Linguagens Documentárias.

\subsection{Definição e Histórico}

A Terminologia preocupa-se com conceitos, definições e denominações, com a compilação, descrição, apresentação, criação e normalização de termos de campos especializados, para fins de comunicação entre especialistas e profissionais. É uma disciplina que permite identificar, de forma sistemática, o vocabulário de uma determinada especialidade e analisá-lo.

De acordo com VALIO e OLIVEIRA (2003, p.116), a Terminologia:

\footnotetext{
${ }^{14}$ Utilizaremos Terminologia com T maiúsculo para nos referirmos à disciplina; terminologia, com t minúsculo, para os produtos concretos.
} 
"estuda os termos de uma área do conhecimento e, portanto, estabelece as características discursivas de cada uma das disciplinas, ou seja, descreve os usos terminológicos oriundos de um sistema de discursos daquela área".

Por suas características, a Terminologia é um campo interdisciplinar que se relaciona com disciplinas como a Lingüística, Lógica, Ontologia, Ciência da Informação, campos de especialidade, Semântica, Filosofia, Psicologia e Lexicologia.

A Terminologia é associada à produção de dicionários e glossários (os produtos terminológicos), mas tem também como função, o planejamento lingüístico e construção de novos vocabulários técnicos, sendo uma ferramenta de comunicação e um elemento de intercâmbio. Além disso, preocupa-se com o estabelecimento de redes de equivalências e correspondências entre línguas, respeitando a integridade de cada uma, a garantia da expressão e comunicação dos usuários de uma área de conhecimento ou atividade, tendo como perspectiva as disciplinas, os usuários, as temáticas trabalhadas e suas finalidades (SAGER, 1991; CABRÉ, 1999; DUBUC, 1999).

De acordo com DUBUC (1977, p.6 citado por LARA, 1999, p.112), a Terminologia "é a arte de identificar, analisar, com o objetivo de criar o vocabulário para uma técnica dada, numa situação concreta de funcionamento, de maneira a responder aos objetivos de expressão do usuário". Isso demonstra, que a língua é "insuficiente para garantir uma comunicação unívoca" (LARA, 1999, p.112).

Seus métodos de trabalho são a coleta ou compilação de termos para identificação das unidades terminológicas; análise, tratamento, processamento e descrição dos termos; apresentação dos termos; criação de termos (neologismo), e normalização. Para isso requer o conhecimento profundo da língua comum, um conhecimento sobre 
a especialidade a ser trabalhada e a identificação de vocabulário conceituais e funcionais. Para a formalização desses processos, a Terminologia utiliza fichas terminológicas, instrumento que reúne elementos que validam a informação (fonte, data, contexto) e mostra a correspondência entre termos. As fichas podem ser apresentadas em banco de dados formadas por vocabulários (repertório de termos acompanhados de definição) ou por léxicos (repertório sem definição dos termos), ou ainda uma mistura dos dois tipos (SAGER, 1991; CABRÉ, 1999; DUBUC, 1999).

Por todas essas características, a Terminologia é uma área que oferece subsídios importantes para o trabalho documentário, ao enriquecer as Linguagens Documentárias com definições fechadas de acordo com a área trabalhada, encurtando o processo que leva à garantia literária.

O trabalho ou a prática terminológica é antigo: já no século XVIII Mendeliev cria a tabela periódica dos elementos da Química, fortemente difundida pelos trabalhos de Lavoisier e Berthold, e em 1735 Linné cria a Classificação Geral dos Seres Vivos, a serviço da Botânica e da Zoologia, a fim de denominar conceitos científicos para atender às necessidades de especialistas de suas áreas. (SAGER, 1990; CABRÉ, 1993).

Com os colóquios internacionais cada vez mais recorrentes a partir do século XIX, a Terminologia começou a aparecer de maneira mais sistemática, devido à necessidade de padronização para a internacionalização das ciências (SAGER, 1990; CABRÉ, 1993).

No século XX são os técnicos que passam a demonstrar a necessidade de dominar novos conceitos e harmonizar suas denominações, necessidades essas ligadas ao intenso desenvolvimento científico e tecnológico. É neste contexto que o engenheiro 
austríaco Wüster e o russo Lotte começam a mostrar seus trabalhos. $O$ alto desenvolvimento da ciência e da técnica, a tecnologia cada vez mais próxima da sociedade, o aumento das relações internacionais, a massificação da produção em ciência e tecnologia, transferência e intercâmbio cultural, científico, técnico e comercial, a informação vista como poder, e o crescimento do impacto dos meios de comunicação de massa, foram as molas propulsoras para o rápido desenvolvimento da terminologia, que passou a atrair a atenção não só de engenheiros, técnicos e cientistas, mas de outros profissionais e pesquisadores como lingüistas, filósofos, cientistas da informação, entre outros (SAGER, 1990; CABRÉ, 1993).

\subsection{Terminologia e Linguagens Documentárias}

Em função do aperfeiçoamento da Linguagem Documentária para a indexação, houve um grande investimento nas metodologias para que esse instrumento incorporasse as funções de controle terminológico, de modo a garantir um tratamento da informação mais consistente, como também a otimização de seu funcionamento na comunicação.

Por ser um instrumento de controle do vocabulário, a Linguagem Documentária deveria apresentar definições precisas das propriedades dos termos por meio de acesso a um vocabulário terminológico. No entanto, isso nem sempre é possível, o que solicita, muitas vezes, o uso de procedimentos terminológicos que assegurem a referência nas áreas trabalhadas e, conseqüentemente, o arranjo estrutural dos termos.

A definição das unidades terminológicas, os termos, é feita a partir do discurso e não

da língua. É o discurso das áreas de atividade e dos domínios do saber que conferem o contexto necessário para a delimitação e interpretação do termo. Os discursos dão a base para o levantamento de repertórios ou listas de termos especializados de um 
domínio particular, inferindo-se daí, por um processo descritivo, suas definições. Nos discursos os termos ganham referência, conforme o que afirma LE GUERN (1989).

As Linguagens Documentárias são formadas por descritores que são unidades preferenciais. O critério para dizer o que é uma unidade preferencial é, ainda, pouco claro, mas se afirma genericamente que os termos utilizados são mais conhecidos dos usuários. Associar a terminologia aos descritores permite incorporar referências do conhecimento produzido numa área, às unidades que funcionam como referências para a informação. A Terminologia exerce uma função comunicativa porque trabalha com unidades do conhecimento, enquanto que a Linguagem Documentária exerce prioritariamente a função referencial, informativa, funcionando como intermediária entre documentos e usuários e, principalmente, entre linguagens: a linguagem dos discursos de especialidade (via terminologia) e a linguagem do sistema de informações.

A Terminologia, conforme LARA (1993b, p.79), "pode fornecer elementos para a restituição de competências semânticas pertinentes, aumentando, dessa forma, a possibilidade de recuperação da informação o desenvolvimento da semiose".

Para compreender melhor o estatuto dos termos, distinguem-se, na Terminologia, palavra e termo. Palavras, para LE GUERN (1989), são independentes das coisas e os termos se referem às coisas, localizando-as em áreas do conhecimento. Para o autor, as palavras têm significado, mas não têm referência e representam propriedades e qualidades de um objeto e não o objeto. Uma palavra passa a ser um termo quando remete a uma classe que foi atribuída a um objeto dentro de um universo determinado. É por essa razão que uma palavra de uma língua não pode ser 
traduzida numa palavra de outra língua, pois os léxicos não recuperam os contextos de uso dos termos. Os termos são ligados uns aos outros através de relações, o que permite que se formem classes de objetos em dado universo, algo que não acontece com as palavras do léxico. O significado é do âmbito do léxico e o conceito pertence ao âmbito da Terminologia. Os termos, portanto, são os veículos dos conceitos.

A melhor forma de compreender o que foi dito acima é pela comparação entre um dicionário de língua e um dicionário especializado. No primeiro, as palavras têm inúmeros significados; no segundo, têm o significado que se localiza numa área de especialidade, correspondendo, portanto, ao conceito.

Considerando o exposto, quando se pensa na organização de conteúdos informacionais por meio de descritores, são os conceitos sua referência, não as palavras.

A Terminologia deve ser vista como uma aliada da Documentação e, mais especificamente, da Lingüística Documentária, quando da elaboração de instrumentos de controle de vocabulário para a indexação e para a recuperação de informações. Ao fornecer os termos de uma área de conhecimento ou atividade, ela também facilita a construção dos mapas de navegação para áreas temáticas específicas e confere consistência ao trabalho documentário na utilização de descritores, o que também facilita o usuário, quer na localização da informação desejada, quer na compreensão do significado do termo veiculado.

As referências principais para o trabalho terminológico estão expressas em normas terminológicas internacionais. Tais normas terminológicas fornecem procedimentos para identificar conceitos e suas relações, analisar e modelar sistemas de conceitos, estabelecer representação desses sistemas através de diagramas, definir os 
conceitos, atribuir termos aos conceitos (designação) em uma ou mais linguagens, apresentar e registrar dados terminológicos (ISO 704, 2000).

Para a Terminologia, um termo é um elemento constitutivo de qualquer sistema conceitual relacionado a uma língua de especialidade. Um termo existe somente em seu próprio campo de aplicação, isto é, dentro do contexto de uma língua de especialidade, na qual seu significado adquire certa particularidade e assume uma carga semântica própria. Por isso, um mesmo termo não pode pertencer a várias áreas temáticas, mesmo que sua forma de expressão seja idêntica: em cada uma delas ele apresentará um significado, remetendo a um conceito particular.

De acordo com suas necessidades, os usuários da língua de especialidade ampliam, restringem ou modificam o significado das palavras da língua geral. Novos significados também podem ser criados para suas próprias necessidades (DUBUC, 1999, p.55-63). Esse procedimento, porém, só aos poucos ganha autoridade, uma vez que o reconhecimento dos processos de re-semantização precisam ser confirmados pelas comunidades que o utilizam.

O termo expressa um conceito pela presença e reunião de traços característicos e significativos do objeto designado, e que supõe, portanto, uma referência à realidade consubstanciada através de discursos de áreas de especialidade.

Segundo as teorias clássicas, dentro de uma especialidade, a um termo deve corresponder somente um conceito, ou seja, deve haver univocidade, meio de garantir uma comunicação mais rigorosa do que a língua geral. A polissemia pode representar sérios inconvenientes, como o risco de conflito entre os significados no interior de uma mesma especialidade ou dentro de suas subáreas. Se a polissemia não puder ser eliminada, será necessário delimitar a área semântica de cada termo. Deve-se 
também eliminar qualquer excesso de sinônimos para preservar a eficácia da comunicação, ou pelo menos, explicitar o alcance real de cada sinônimo. As teorias contemporâneas da Terminologia não ignoram a polissemia, sendo mais tolerantes à variação.

A relação entre termo e conceito pode ser determinada segundo o conteúdo semântico de cada conceito, por meio de relações lógicas de gênero/espécie, causa/efeito, ou pelas relações associativas abstrato/concreto, parte/todo, objetivo/meio e relações de oposição. As relações do segundo tipo servem mais para explicar os conceitos do que para classificá-los. Aqui fica evidente a importância de um sistema de conceitos bem delimitado com a explicitação dos termos que, dentro da língua de especialidade se relacionam. Fica evidente, também, a presença da noção de estrutura, como sistema de relações mútuas entre os conceitos, garantia de sua significação.

Por meio do trabalho terminológico de construção do sistema relacional de conceitos, é possível formar um mapa da área estudada e entender o que cada termo significa em relação ao campo em que se localiza. Os procedimentos terminológicos tornam mais clara a razão dos sistemas de relacionamentos propostos pelas diretrizes de elaboração de tesauro, porque simulam, a seu modo, a definição.

A Terminologia é imprescindível para traduzir a linguagem técnica e científica numa linguagem sistêmica, como vemos em SAGER:

"A terminologia constitui para os especialistas o vocabulário essencial para uma comunicação eficaz. Para o grande público não é mais do que um modo dos especialistas enganarem, confundirem ou impressionarem com conhecimentos superiores ou com uma linguagem arcana que protege os mistérios do saber. Para alguns poucos, é uma das chaves do progresso que permite acessar o 
mundo das ciências e técnicas" (SAGER, 1993, p.11, citado por LEAL, 1998, p.31).

O grande avanço no campo das metodologias de análise e síntese deu-se pelo reconhecimento da importância das terminologias e do reconhecimento das estruturas textuais para análise da informação. Porém, pouco se avançou nas propostas de novos produtos documentários ou de novos processos de transferência efetiva de informação. É preciso evoluir no desenvolvimento de interfaces entre a terminologia e a lingüística documentária, estabelecendo uma relação complementar entre dois pontos de vista, o do codificador e do consumidor da informação (TÁLAMO, 2001).

Para CABRÉ (1999), a relação entre Terminologia e Documentação se dá pelos dois lados: uma precisa da outra para seus processos de trabalho. Uma vez que o objetivo fundamental do trabalho documentário é facilitar a recuperação de informações, a Documentação necessita de descrições explícitas de cada documento de forma a permitir sua identificação completa e de uma estrutura organizada de assuntos dentro da área em que se situa. A descrição do documento é realizada para a explicitar os elementos mais representativos da informação a ser transmitida. A indexação, portanto, pode ser vista como uma operação também terminológica, uma vez que detecta a terminologia mais indicativa do conteúdo documentário.

No trabalho documentário, além da Terminologia ser utilizada como um instrumento de descrição e indexação de informação, também é utilizada como um instrumento de recuperação. Segundo CABRÉ, para adaptar-se a estes dois procedimentos, a Documentação necessita de uma Terminologia descritiva e normativa. Isto, ao mesmo tempo em que favorece a recuperação de informações pela sistematização dos conteúdos, acaba por forçar a naturalidade expressiva do usuário. Tornam-se necessárias, portanto, discussões e apresentação de trabalhos conjuntos entre 
documentalistas e terminólogos, no sentido de potencializar a capacidade comunicativa e de intermediação das Linguagens Documentárias subsidiadas por terminologias, os tesauros terminológicos (idem, 1999).

Na ótica da Documentação, porém, verifica-se que o entendimento que CABRÉ (1999) tem da área não é completo. A autora confunde os processos de indexação e de construção de vocabulário, não compreendendo que a função da Terminologia se relaciona ao segundo processo, não ao primeiro.

As pesquisas sobre construção de vocabulários têm hoje, na Terminologia, uma referência fundamental para o estabelecimento de redes relacionais que permitam conferir aos descritores significados interpretáveis em determinadas áreas de especialidade. Isso facilita o processo posterior de indexação, já que o controle terminológico está feito anteriormente,

Uma Linguagem Documentária pode representar uma espécie de mapa temático com os conceitos de uma área, e não apenas de textos tomados na sua individualidade, como é o caso do resumo (CINTRA e outras, 1994). Uma das principais contribuições da Terminologia para a elaboração das Linguagens Documentárias está na ênfase da noção de relação explorada pela área. Essa noção, que se manifesta na linguagem, como vimos anteriormente, também é fundante na Terminologia, uma vez que ela torna possível a compreensão dos elementos envolvidos na formulação de classes.

É preciso dizer que a Terminologia tem diferentes vertentes de pensamento. No que diz respeito às linhas, CABRÉ (1999) ressalta o desenvolvimento de três abordagens terminológicas: Terminologia orientada ao sistema lingüístico (corrente lingüísticoterminológica), encabeçada por Wüster, e com grande preocupação normalizadora; a Terminologia orientada à tradução (corrente traducional), que surgiu em regiões 
francofônicas em organismos internacionais, que propõem a criação de bancos de dados terminológicos; e a Terminologia orientada à planificação lingüista (corrente normalizadora), que se preocupa com a recuperação de línguas minoritárias, por meio de intervenção sistemática e legal. Segundo sua opinião, no caso da documentação, é a primeira linha que interessa. Essa não é, entretanto, uma opinião compartilhada por grande parte dos documentalistas que reconhecem o benefício de outras tendências de estudos da Terminologia. O principal deles é o que se relaciona à comunicação e que não vê a função da linguagem apenas como meio de designação posterior à formação do conceito (LARA, 2006).

Em uma comparação simplificada entre Linguagem Documentária e Terminologia (instrumento), temos:

\begin{tabular}{|c|c|c|}
\hline Aspectos & LD & Terminologia \\
\hline Unidade & - Descritor Preferencial & - Termo \\
\hline Universo de Trabalho & $\begin{array}{l}\text { - Linguagem dos usuários } \\
\text { - Textos sob indexação }\end{array}$ & - Linguagem especializada \\
\hline Forma & $\begin{array}{l}\text { - Mapa conceitual } \\
\text { - Grade interpretativa } \\
\text { - Equivalência entre } \\
\text { linguagens }\end{array}$ & - Guia de definições \\
\hline Métodos e Operações & $\begin{array}{l}\text { - Hipótese de organização } \\
\text { - Rede de relações } \\
\text { - Prioritariamente, processo } \\
\text { onomasiológico (do conceito } \\
\text { ao nome) }\end{array}$ & $\begin{array}{l}\text { - Identificação, análise, criação } \\
\text { - Processo semasiológico (do } \\
\text { nome ao conceito) e } \\
\text { onomasiológico (do conceito } \\
\text { ao nome) }\end{array}$ \\
\hline Função & $\begin{array}{l}\text { - Representação da } \\
\text { Informação } \\
\text { - Recuperação de informação } \\
\text { - Controle do vocabulário }\end{array}$ & $\begin{array}{l}\text { - Comunicação de conceitos } \\
\text { - Normalização/prescrição (na } \\
\text { Terminologia clássica) } \\
\text { - Descrição (na Terminologia } \\
\text { contemporânea) }\end{array}$ \\
\hline Propósito & $\begin{array}{l}\text { - Consulta por indexadores e } \\
\text { usuários das informações }\end{array}$ & - Consulta por especialistas \\
\hline Unidade & Descritor /unidade preferencial & - Termo \\
\hline Instrumento & - Tesauro & $\begin{array}{l}\text { - Repertórios terminológicos } \\
\text { - Dicionários terminológicos } \\
\text { - Glossários } \\
\text { - Bancos terminológicos }\end{array}$ \\
\hline
\end{tabular}

Quadro 17 - Comparação entre Linguagem Documentária e Terminologia 
Uma Linguagem Documentária é um objeto cultural que registra e representa a informação segundo parâmetros estáveis do conhecimento. São instrumentos que manifestam as relações entre os termos forma de redes de relações. A escolha dos descritores e do seu modo de organização determina as formas e o conteúdo das operações de indexação.

A Terminologia é, portanto, fundamental para subsidiar a elaboração de Linguagens Documentárias, pois é através delas que é possível identificar as referências para a seleção dos termos e a apreensão dos conceitos relacionados. Sem o apoio da Terminologia (teórica) e as terminologias concretas, qualquer operação de seleção e organização das estruturas relacionais são desprovidas de fundamento nas áreas de conhecimento ou de atividade que são seu foco. Confirma-se, pelo exposto, que as noções de estrutura lingüística estão na base, também, das terminologias. A expansão da noção de estruturação se encontra na forma como as terminologias são validadas: elas não partem de conceitos formulados de modo abstrato, mas da observação dos discursos efetivamente realizados, além de compartilhados pelas comunidades de uso, seja em nível científico ou técnico. 


\section{Análise de Linguagens Documentárias}

A reunião dos conceitos feita anteriormente permite uma verificação mais detalhada dos vários tipos de instrumentos utilizados na Documentação. Para tanto, procuraremos agora proceder à análise de Linguagens Documentárias mais usadas atualmente, bem como outros instrumentos que se assemelham, ao menos em parte, a elas. A finalidade desse exercício é a de verificar como integram os conceitos lingüísticos e terminológicos, mais especificamente, se e como aplicam de fato a noção de estrutura em sua organização.

Para efeito de análise, tomaremos a síntese da noção de Linguagem Documentária: o sistema de relações entre os descritores e o respaldo no uso, via referências nas terminologias utilizadas pelas comunidades discursivas específicas.

\subsection{Vocabulários Controlados}

Vocabulários controlados são listas organizadas de palavras e frases utilizadas para nomear conteúdos e recuperar a informação. Auxiliam na categorização de conteúdo e sua análise, servindo à indexação de textos e no estabelecimento da navegação de páginas eletrônicas (sites), com o objetivo de diminuir a ambigüidade que pode surgir na relação entre usuários e sistemas de informação.

Para GOMES (1990, p.15) um vocabulário controlado "contém apenas relações sinonímicas, quase sinonímicas, bem como controle de polissemia, além de não diferenciar rigorosamente "termo" de "palavra". E também não apresenta relações estruturais entre os elemento". 
De acordo com GREIMAS e COURTÉS (1979, p.492), vocabulário é "a lista exaustiva das palavras de um corpus (ou de um texto) por oposição ao léxico, entendido com inventário de todas as lexias de um estado de língua natural”.

O glossário da ALA - American Library Association, define vocabulário como "número limitado de palavras, expressões ou códigos a disposição de uma pessoa, uma máquina ou um sistema" (YOUNG, 1988, p.366).

DUBOIS e outros (1973, citado por CINTRA e outras, 2002, p.37) afirmam que vocabulário "refere-se ao conjunto de ocorrências que integram um determinado corpus discursivo, como uma lista de unidades da fala".

A Norma ISO 1087-1 define vocabulário como "dicionário terminológico que contém designações e definições de um ou mais campos de conhecimento" e que pode ser monolíngüe, bilíngüe ou multilíngüe (2000, p.12). Ressalte-se que esta definição ocorre no contexto da Terminologia, o que confere características particulares ao termo 'vocabulário'. Não se pode interpretar, do mesmo modo, o conceito de vocabulário utilizado na Documentação.

Os vocabulários, para GARDIN (1966), são léxicos documentários, que podem ou não ser organizados. Podemos, a seguir, registrar, em um quadro, algumas das de características gerais dos vocabulários controlados apontadas acima: 


\begin{tabular}{|l|}
\hline \multicolumn{1}{|c|}{ Características } \\
\hline Controle de vocabulário e de sua ambigüidade \\
\hline Listas organizadas de expressões \\
\hline Função de recuperação de informação \\
\hline Função de Indexação \\
\hline Número limitado de palavras \\
\hline Ordem alfabética de apresentação de suas expressões \\
\hline Pode apresentar definições de suas expressões \\
\hline Pode ser monolíngüe, bilíngüe ou multilíngüe \\
\hline Aborda um ou mais campos de conhecimento \\
\hline
\end{tabular}

Quadro 18 - Características gerais dos vocabulários controlados

O modo como os vocabulários realizam o 'controle', no entanto, é seu aspecto problemático. Dentre todas os requisitos que são utilizados para o controle do vocabulário em uma Linguagem Documentária, os denominados 'vocabulários controlados' têm alguma das características, mas nem todas. LARA afirma que:

"Controlar o vocabulário não significa apenas padronizar as formas de entrada (significantes) ou registrar a sinonímia: significa operar sobre a significação (significante/significado) dos termos, o que depende inteiramente de delimitações de sentido conferidas pela rede de relações lógico-semânticas amparadas por definições" (2001b, p.4).

Além do mais, falta a esses vocabulários, geralmente, relações de natureza associativa - como os TR dos tesauros - relação essa fundamental para reforçar a carga semântica de um termo.

Pelas suas características, não se pode afirmar que os vocabulários controlados integrem todas as características da noção de estrutura, seja como sistema de relações autônomo - que dá forma global à Linguagem Documentária - seja como modo de estruturação que se apóia no uso. 


\subsection{Esquemas de Classificação}

Os planos de classificação foram construídos tendo como referência o conhecimento universal ou áreas especializadas do conhecimento. De acordo com CINTRA e outras (2002, p.40-1):

"Os primeiros sistemas de classificação bibliográfica conhecidos são os de natureza enciclopédica, como a CDD - Dewey Decimal Classification, a CDU - Classificação Decimal Universal e a LC Library of Congress, e visam cobrir todo o espectro do conhecimento. Sistemas posteriores como as classificações facetadas desenvolvidas a partir do CRG - Classification Research Group, com base na Colon Classification, de Ranganathan, visam a domínios particulares. Os tesauros, por seu lado, originaram-se de classificações facetadas com uma preocupação adicional: a do controle do vocabulário".

Os esquemas de classificação, tanto os de propósitos universalistas, como os de classificação especializada, acabam por se tornar rígidos e acompanham com dificuldade a dinâmica da linguagem e do conhecimento a ser representado, uma vez que não se caracterizam pelo contexto da organização e dos usuários a quem servem - são pré-formatados, sendo utilizados com os mesmos termos e relações sejam quais forem as aplicações.

Por pretenderem a organização física de documentos, os sistemas de classificação geralmente limitam a representação de conteúdo a classes disciplinares, impedindo uma adequada classificação de temas que são produto de cruzamento entre elas.

Apesar de serem excessivamente hierárquicos, alguns sistemas de classificação bibliográfica também dispõem de operadores de relação entre os termos que não são 
de inclusão. Segundo afirmação de LARA $(2000)^{15}$, esquemas de classificação como a Classificação Decimal de Dewey (CDD) e Classificação Decimal Universal (CDU) apresentam dois recursos de sintagmatização:

"primeiro, através da construção de notações que agregam a notação relativa ao assunto principal - que corresponderia ao tema - às notações relativas a aspectos complementares (onde, como, em que língua, sob que ponto de vista,); segundo através da combinação de notações de assuntos principais para formar um novo assunto (mecanismo identificado como síntese notacional" (idem).

A CDU conta ainda com recursos adicionais para a combinação livre de quaisquer assuntos, sem especificar, porém, a natureza da relação ou qual o assunto predominante (idem).

De acordo com LARA (2001a, p.4), "os sistemas de classificação pressupõem a existência de uma visão de mundo homogênea, estável e, de certo modo, imutável". O conteúdo de suas classes é organizado e de modo dedutivo, o que reforça a noção de conhecimento como acúmulo (idem, p.4). Assim, "a CDD e CDU são mais aptas antes a prover uma base para a formação de estoques e para a reprodução do conhecimento do que promover a circulação de informação" (idem, p.4), ou seja, são esquemas mais adequados para "a preservação de acervos (e de pontos de vista já fixados) do que à transferência da informação" e falham quanto à função de prover processos de comunicação (idem, p.8). Além disso, os sistemas de classificação não apresentam preocupação como o controle de vocabulário (idem, p.9).

\footnotetext{
${ }^{15}$ Anotações da disciplina Linguagens Documentárias, do segundo semestre de 2000 , ministrada por Marilda Lopes Ginez de Lara.
} 
Da noção de estrutura, os sistemas de classificação utilizam principalmente a relação hierárquica de inclusão. As associações não-hierárquicas previstas são reduzidas: previstas no sistema (CDD) e abertas pelas possibilidades de uso dos operadores de relação (CDU). A hierarquia, no entanto, prevalece sobre as relações de associação.

\subsection{O SYNTOL}

Dentre inúmeras Linguagens Documentárias já analisadas em outros trabalhos (WANDERLEY citado por DODOBEI, 2002; LARA; DODEBEI; CHAUMIER, etc), o SYNTOL é uma Linguagem Documentária que utiliza fortemente os conceitos da lingüística estruturalista.

De acordo com CROSS e outros (1968, p.39), o SYNTOL é "um conjunto de regras lógico-semânticas sobre diferentes maneiras de representar as informações trazidas na documentação científica".

A grande inovação do SYNTOL é conjugar organização semântica e organização sintática, a fim representar o máximo de informação possível em sistema de informação virtualmente aberto. Para isso GARDIN e sua equipe passaram a considerar explicitamente a aplicação de relações sintagmáticas. A análise destas permite "exprimir as relações que unem as palavras de uma cadeia escrita, quaisquer que sejam essas palavras" (CROSS e outros, 1968, p.44). Procura-se, no SYNTOL, assegurar a univocidade das reduções sintáticas, da linguagem natural à Linguagem Documentária, e garantir a maleabilidade das expressões finais, isto é, permitir a redução ou ampliação do grau de precisão da análise (idem). 
A organização semântica é feita com um sistema de regras de construção dos sintagmas e com uma indicação temática que eventualmente salienta em um sintagma ou grupo de sintagmas a o seu foco. A indicação temática é considerada pelos autores cmo procedimento sintático. Entretanto, GRANGER observa que este procedimento também pode ser considerado de natureza semântica: "a razão que o vincula à sintaxe é que ele tem por função levantar certas ambigüidades não resolvidas pelas regras sintagmáticas" (1974, p.212).

GRANGER considera o SYNTOL como uma Linguagem Documentária "pragmaticamente válida" e também como uma imagem simplificada da linguagem natural (idem, p.215).

De acordo com LARA (2001b, p.5), o SYNTOL é um "modelo de linguagem aplicável teoricamente a quaisquer universos de textos, cuja ênfase está na identificação de relações de natureza paradigmática e sintagmática entre os termos". È um trabalho considerado de grande atualidade e que influenciou e influencia as pesquisas subseqüentes.

\subsection{Tesauros}

O tesauro é uma Linguagem Documentária, um objeto cultural que registra e representa o conhecimento segundo parâmetros estáveis, previamente determinados e manifestos sob a forma de redes de relações entre descritores que determinam o seu modo de organização, a disseminação da informação e a análise dos documentos. O termo tesauro é de origem greco-latina, e o Oxford English Dictionary (citado por GILCHRIST, 2003, p.7) o define como: 
"um "tesouro" ou "depósito" de conhecimento, como um dicionário, uma enciclopédia ou similar. Uma coleção de conceitos ou palavras ordenadas de acordo com o sentido; também um dicionário de sinônimos ou antônimos".

Enquanto produto documentário, o tesauro tem sua origem no século $\mathrm{XIX}$, mais precisamente em 1805, com o aparecimento da primeira lista de palavras classificadas de acordo com o seu significado, graças à iniciativa de Peter Mark Roget (CAVALCANTI, 1978, p.27).

The Roget's Thesaurus ${ }^{16}$ ficou conhecido como o primeiro trabalho desta natureza e congregava uma relação de palavras e combinações idiomáticas organizadas não em ordem alfabética, como em um dicionário, mas de acordo com as idéias que expressavam. Mesmo assim, GILCHRIST (2003, p.8), cita os trabalhos de SPARCK JONES $(1972)^{17}$ e MCARTHUR $(1986)^{18}$, que fizeram uma ligação entre o tesauro de ROGET com o Essay towards a Real Character and a Philosophical Language de WILKINS $(1668)^{19}$. WILKINS pretendia construir uma nova linguagem que substituísse o latim, de forma a reduzir as ambigüidades na comunicação científica universal e, desse modo, promover o avanço da ciência.

O termo tesauro permaneceu pouco utilizado até meados do século $X X$, quando foi retomado de forma discreta, mas relacionado à tradução automática ou mecânica (CAVALCANTI, 1978, p.27).

${ }^{16}$ ROGET, P.M. Thesaurus of English Words and Phrases. London; Harlow: Longman, 1852.

${ }^{17}$ SPARCK JONES, K. Some thesauric history. Aslib Proceedings, v.24, n.7, July, p.400-11, 1972.

${ }^{18}$ MCARTHUR, T. Worlds of Reference. Cambridge: Cambridge University Press, 1986.

${ }^{19}$ WILKINS, J. An Essay towards a Real Character and a Philosophical Language. London, 1668. 
Para LARA (1993b, p.102-3), no âmbito da Biblioteconomia,

"a origem dos tesauros se reporta à Colon Classification - CC, de Ranganathan e às experiências posteriores desenvolvidas pelo Classification Research Group - CRG, referentes à estruturação das áreas do conhecimento a partir da noção de "faceta", ou seja, do privilégio de determinados pontos de vista sobre o arranjo dos domínios e subdomínios".

Com o crescimento de sua utilização, o tesauro passou a designar uma lista de descritores ou termos de indexação - unidades utilizadas para representar e recuperar informação -, e ganhou a função de representar conceitos e especificar relações entre os termos.

De acordo com LARA (2001b, p.5), nos tesauros "a ênfase não se dirige mais às classes de assuntos e as disciplinas convencionais", mas às relações associativas entre os termos. São instrumentos "voltados para o objeto, ou mais precisamente, para os conceitos orientados ao objeto". Assim, são elaborados a partir de necessidades específicas, podendo haver dentro de uma mesma área ou domínio, diversos tesauros contemplando, cada um, um aspecto do campo tratado (idem, p.5).

Os tesauros, diferentemente dos esquemas de classificação e dos vocabulários controlados, contam com diretrizes e normas para sua elaboração. De acordo com as diretrizes para tesauros monolíngües, um tesauro é "uma linguagem documentária dinâmica que contém termos relacionados semântica e logicamente, cobrindo de modo compreensivo um domínio do conhecimento" (GOMES, 1990, p.16).

O tesauro é uma Linguagem Documentária que se apóia (ou deveria se apoiar) na linguagem de especialidade. A linguagem de especialidade identifica a linguagem que é utilizada em domínios do conhecimento ou em áreas de atividade, e que tem parte 
'especializada', e parte da linguagem natural. Ao se apoiar na linguagem de especialidade, o tesauro especifica o seu contexto temático de aplicação e uso, de modo a permitir que a relação significado/significante seja interpretada nesses ambientes. Garante-se, desse modo, maior univocidade dos termos.

Pode-se dizer que, nos tesauros, o significado de 'controle' é mais amplo, porque utilizam um sistema mais completo de relações, apoiando-se, em alguns casos, em definições terminológicas, que têm em sua gênese relações estruturais. Para LARA (2001b, p.6),

"os tesauros constituem o primeiro instrumento documentários de representação que trabalha com a noção de controle do vocabulário. (...) O controle é aqui entendido não sob a perspectiva da padronização, mas como o mecanismo através do qual busca-se estabelecer a interação dos sistemas com os seus público".

As relações no tesauro compreendem um rol mais sofisticado que os sistemas de classificação e os vocabulários controlados em geral. No tesauro, os relacionamentos procuram reproduzir o sistema da língua, e "as redes lógico-semânticas entre os descritores permitem estabelecer um sistema de significação que corresponde a uma hipótese de organização relativa a um domínio" (LARA, 2001b, p.6).

Segundo as metodologias de tesauro, como as diretrizes comentadas por GOMES (1990), as relações que o caracterizam são:

a) Relação de equivalência: relação entre o termo preferido e o não-preferido. É o caso de sinônimos ou quase-sinônimos. Opta-se por um termo que será o preferido. 
b) Relação hierárquica: é a relação que distingue um tesauro sistemático de uma lista de termos não estruturada, por exemplo, um glossário. Baseia-se na superordenação e subordinação dos termos e cobre três situações:

a. Relação genérica - Indica vínculo entre a classe ou categoria e seus membros e espécies

b. Relação hierárquica todo-parte - Aplica-se em situações onde o nome de uma parte implica o nome de seu possuidor.

c. Relação de Exemplo - Ligação entre uma categoria geral de objetos ou evento e um exemplo individual.

c) Relação associativa: cobre a relações entre pares de termos que não são membros de um conjunto de equivalência nem podem ser organizados em uma hierarquia onde um termo se subordina o outro. Entretanto são mentalmente associados de tal maneira que a conexão entre eles deve ser feita explicitamente no tesauro.

Além disso, o tesauro utiliza operadores de sentido para indicar as relações entre suas unidades:

- $\quad$ TG - Termo genérico: indica termo de maior abrangência;

- TE - Termo específico: indica termo de maior especificidade;

- $\quad$ TR - Termo relacionado: indica relação associativa, não hierárquica;

- UP - Usado Para: indica sinônimo ou quase-sinônimo, equivalência;

- USE - Use: indica o termo preferido;

- NE ou NA: Nota Explicativa ou Nota de Aplicação: indicam definições ou explicações para o uso do termo. 
A rede de relações do tesauro se baseia num esquema de equivalências. Quando dois ou mais significantes concorrem para o mesmo conceito, eles têm sua distribuição equivalente, e são criadas relações remissivas, fazendo com que se chegue de fato ao conceito desejado. As distribuições de equivalência parcial representam as relações hierárquicas, de termo genérico e termo específico, onde este tem as mesmas características do primeiro, acrescida de uma diferença. A norma tem papel fundamental: dos termos recolhidos da língua, escolhe-se apenas os pertinentes ao contexto trabalhado, eliminando-se variáveis. Transforma-se o tesauro em um subcódigo que representa uma leitura possível da realidade de uma área.

Procura-se compatibilizar os diversos termos usados na linguagem natural com um termo que defina mais apropriadamente o conceito que se deseja representar ou acessar dentro de um determinado sistema de informação. Para que a cada termo preferido do tesauro corresponda a somente um conceito ou noção, é necessário um controle do vocabulário. Esse controle é obtido por dois meios principais:

a) A cada termo do tesauro corresponde apenas um significado, que é o mais adequado às necessidades do sistema de indexação - univocidade -, ao contrário dos termos de um dicionário que podem estar acompanhados de várias definições. Caso o significado do termo não estiver expresso suficientemente, acrescenta-se uma definição ou nota explicativa. Esta forma também é chamada de normalização semântica.

b) Quando um mesmo termo puder ser expresso por dois ou mais sinônimos ou quase-sinônimos, escolhe-se um destes como o termo preferido, isto é, termo que será utilizado na indexação. Os outros termos servirão como pontos de acesso, ao levar ao termo preferido. 
Desse modo, o tesauro operacionaliza, mais do que os sistemas de classificação e os vocabulários controlados, a noção de estrutura como rede de relacionamentos entre os termos.

As finalidades do tesauro são, de acordo com FUJITA (1992, p.9), o controle dos termos de indexação e recuperação da informação, assegurar uniformidade entre os indexadores, e servir como auxílio para estratégias de busca.

O tesauro é, portanto, um instrumento de controle do vocabulário que possibilita a indexação da informação, a recuperação desta com qualidade e a redução das ambigüidades oriundas da linguagem natural.

De acordo coma LARA $(2000)^{20}$, "somente as relações lógico-semânticas são objeto do tesauro. As relações sintáticas não fazem parte do tesauro, mas são constituídas a partir dele". As primeiras são relações fixadas a priori no tesauro, no eixo paradigmático, e as outras são relações de combinação dos termos na saída do sistema - estas são relações sintagmáticas.

As relações do tesauro determinadas a priori, dão a ele a sua armação, como uma analogia à estrutura do domínio a ser trabalhado. As relações a posteriori , permitem que se criem novos sintagmas documentários a partir da combinação de descritores definidos a priori, o que responde pela dinamicidade do tesauro. As relações a posteriori, no entanto, dependem muito do repertório de descritores existentes originalmente, o que é um problema, já que não se garante, efetivamente, que a noção de estruturação contínua seja alcançada.O tesauro é um instrumento que adquiriu

\footnotetext{
${ }^{20}$ Anotações de aula.
} 
estabilidade, mas esta tem sido comprometida pelo surgimento relativamente rápido da busca em texto integral (full-text) e também pela internet, ainda que sem levar em conta as características semânticas dos conteúdos da rede. A partir desse quadro, aparece o "tesauro de busca", que seria uma fusão de tesauros, cuja principal característica é o agrupamento de sinônimos (COCHRANE, 1992 ${ }^{21}$, citado por GILCHRIST, 2003, p.9).

De acordo com MILSTEAD ${ }^{22}$ (1995, citado por GILCHRIST, 2003, p.10) "o tesauro pode se tornar invisível para a maioria dos usuários", o que leva à questão das taxonomias, discutidas mais adiante. Além disso, para MILSTEAD,

\begin{abstract}
"não há um motivo intrínseco para que um tesauro convencional não possa ser ampliado e elaborado para incluir, por exemplo, definição de termos, notas de uso, e definição mais explícita dos relacionamentos, (...) e tal enriquecimento do tesauro permite que a rede semântica seja manipulada mais facilmente por um motor de inferência".
\end{abstract}

Neste ponto, o tesauro converge para as ontologias (GILCHRIST, 2003, p.10), que também serão referidas adiante.

Pelo exposto, pode-se afirmar que, dentre os instrumentos vistos até agora, é o tesauro que mais utiliza a noção de estrutura como rede relacional. No entanto, ele ainda se caracteriza como uma ferramenta pré-construída, que impede a realização de

${ }^{21}$ COCHRANE, P.A. Indexing and searching thesauri, the Janus or Proteus of information retrieval. In: WILLIAMSON, N.J.; HUDON, M. (Eds), Classification Research for Knowledge Representation and Organization. Amsterdam: Elsevier Science Publishers, 1992.

${ }^{22}$ MILSTEAD, J. Invisible thesauri: the year 2000, Online \& CDROM Review, v.19, n.2, p.93-4, 1995. 
uma reestruturação com o uso. São necessárias novas edições para que esta condição seja atendida, mas, assim feita, ela se cristaliza.

\title{
5.4.1. O Tesauro Funcional
}

O tesauro funcional foi desenvolvido para dar conta da indexação de documentos de arquivos administrativos correntes. Foi uma iniciativa do Arquivo Nacional da Austrália, e é definido, conforme o NATIONAL ARCHIVES OF AUSTRALIA (2000) como:

\begin{abstract}
"uma lista alfabética de todas as funções autorizadas e os termos descritores de atividades derivam de um plano de classificação de negócios. Define-se os termos usando notas de escopo e especificando as relações hierárquicas entre eles".
\end{abstract}

Assim como o tesauro documentário, um vocabulário controlado - como o tesauro funcional - , na ótica arquivística, deve (SMIT e KOBASHI, 2001, p.14-5):

- Hierarquizar as atividades pelas funções, ao possibilitar tanto a visualização do universo coberto, como a orientação para o arranjo das séries documentais.

- Contemplar a sinonímia, ao orientar tanto a nomeação dos documentos como as buscas.

- Relacionar termos presentes em diferentes categorias, caso seja necessário.

- Preocupar-se com a conceituação dos termos, através de notas explicativas as notas de escopo.

O tesauro funcional deve representar, no topo de sua hierarquia as funções de negócios gerais, no segundo nível, representar as atividades que constituem tais 
funções e, no terceiro nível e nos subseqüentes, representar os grupos de transações que se sucedem e que tomam lugar dentro dessas atividades. Veja na figura seguir:

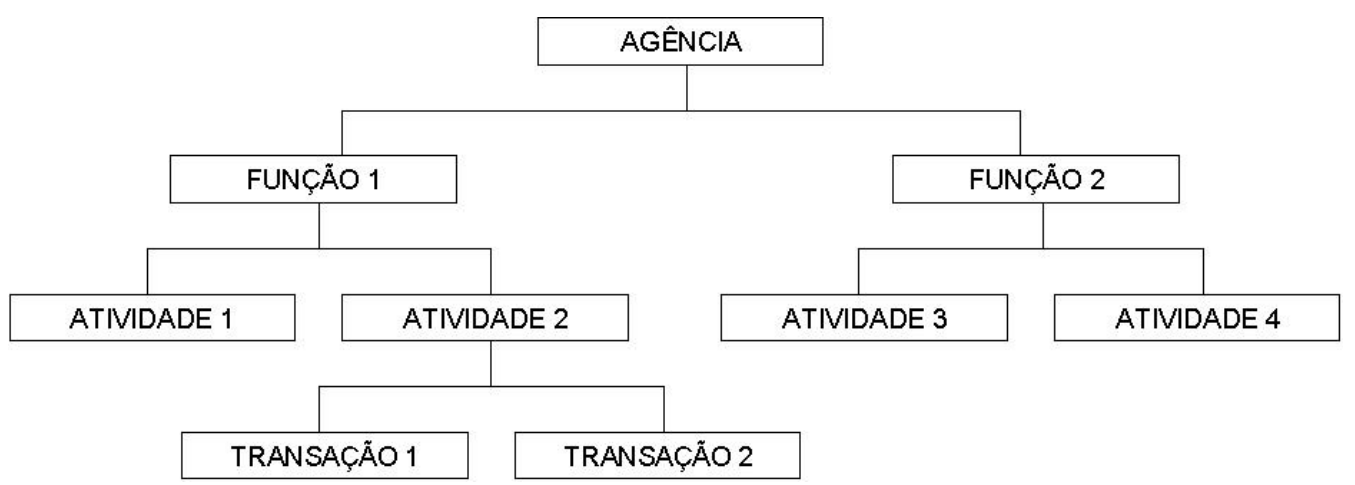

Figura 3 - Esquema de Classificação de Negócios

FONTE: ARCHIVES AUTHORITY OF NEW SOUTH WALES, 1998

Seguindo a mesma ordem, a estrutura do tesauro funcional apresenta-se da seguinte forma:

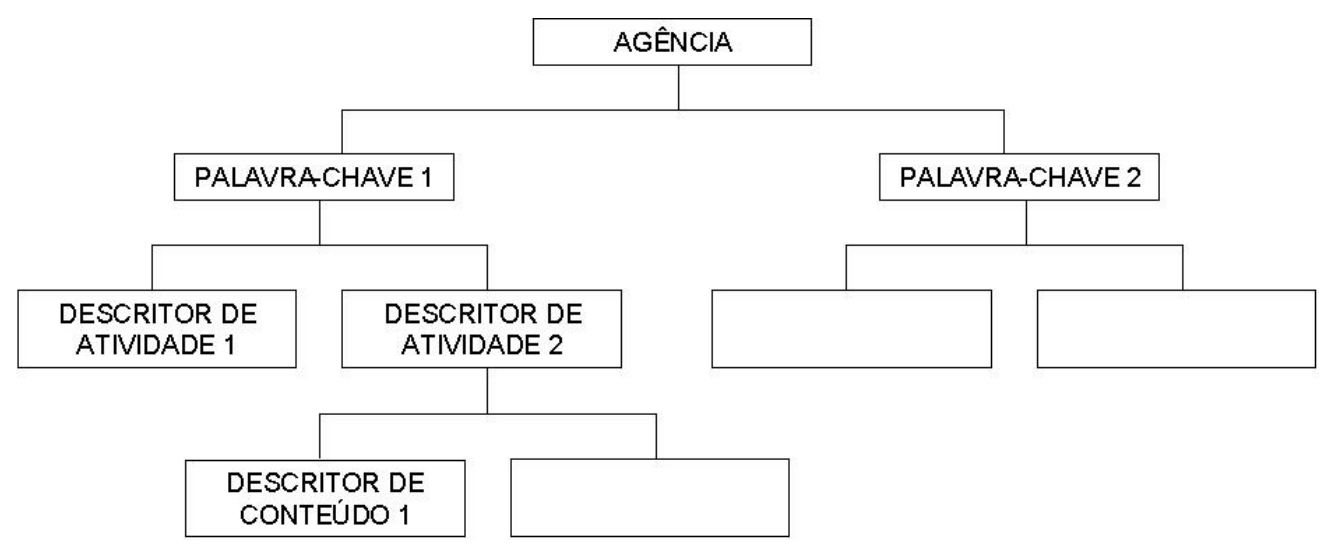

Figura 4 - Estrutura do Tesauro

FONTE: ARCHIVES AUTHORITY OF NEW SOUTH WALES, 1998 
Assim, tem-se:

- Palavras-chave que representam funções gerais de negócios de uma agência;

- Descritores de atividade que descrevem atividades mais específicas que tomam lugar entre aquelas funções, e

- Descritores de conteúdo colocados como um meio de descrever conteúdos ou tópicos mais específicos relacionados com o assunto a ser documentado dentro de uma atividade.

As palavras-chave e os descritores são fornecidos pelo tesauro e podem ser acrescidos de algum texto livre, isto é, palavras não derivadas do tesauro, como o nome de uma organização, de um indivíduo ou de um projeto. Portanto, a documentação de um arquivo é construída ao alocar-se uma palavra-chave, seguida de um descritor de atividade, seguido de um descritor de conteúdo e/ou algum texto livre. Além disso, ao aplicar-se o tesauro funcional baseado nas funções de negócios, os registros podem ser indexados e documentados e pode-se determinar como eles devem ser mantidos, armazenados e quem deve acessá-los (ARCHIVES AUTHORITY OF NEW SOUTH WALES, 1998). A palavra-chave, neste contexto, pode ser entendida como a categoria nos tesauro conceituais. Seu uso não ocorre para a indexação em si, mas para um mapeamento da função representada.

O tesauro funcional é, portanto, mais flexível, permitindo a representação de estruturas nocionais na dependência dos aspectos a serem observados na documentação analisada. 


\subsubsection{O Tesauro Terminológico}

No trabalho documentário, a Terminologia pode ser utilizada como um instrumento de descrição e indexação de informação, e também como um instrumento de recuperação das mesmas. Para adaptar-se a estes dois procedimentos, a documentação necessita de uma Terminologia descritiva e normativa. Isto, ao mesmo tempo em que favorece a recuperação de informações pela sistematização dos conteúdos, acaba por forçar a naturalidade expressiva do usuário. Tornam-se necessárias, portanto, discussões e apresentação de trabalhos conjuntos entre documentalistas e terminólogos, no sentido de potencializar a capacidade comunicativa e de intermediação das LDs subsidiadas por terminologias, os tesauros terminológicos.

De acordo com LARA (2001b, p.8):

\footnotetext{
"Contemporaneamente, as linguagens documentárias tendem a se apresentar sob a forma de tesauros terminológicos, acoplando, no mesmo instrumento, uma rede de termos preferenciais (selecionados a partir da terminologia concreta e das referências de uso) e um glossário: além das notas de escopo, que são notas explicativas quanto às possibilidades e restrições de uso de um descritor, os tesauros terminológicos incorporam definições".
}

Os tesauros terminológicos, dessa forma, são "instrumentos que usam simultaneamente princípios de organização de tesauros e de organização de sistemas de conceitos" (LARA, 2002a, p.134). Assim, contam com todas as características de um tesauro convencional, acrescentando-se uma rigorosa seleção de termos que já foram delimitados no seu domínio. 
De acordo com CINTRA e outras, a ausência de definições e a presença escassa de Notas de Escopo, fazem com que as Linguagens Documentárias não funcionem efetivamente como meio para uma interpretação consistente (1994, p.78-79).

"A não fixação do sentido compromete a credibilidade do instrumento lingüísticodocumentário para o tratamento e a recuperação da informação" (CINTRA e outras, 1994, p.81). Para resolver esta questão, é necessário estabelecer o universo referencial das Linguagens Documentárias, por meio das terminologias de áreas. Isso porque, de acordo com as autoras (1994, p.79), "na Terminologia, uma palavra designa um determinado objeto, porque trabalha com traços de substância e remete a determinados universos de valores consubstanciados nos discursos de especialidade".

O capítulo sobre Terminologia, neste trabalho, confirma o que foi dito acima. Seria um tesauro terminológico um instrumento mais refinado, já que conjuga um sistema de relações com as definições que Ihe dão sustentação, além de facilitar a compreensão dos termos. Como também já foi dito, um instrumento desse gênero utiliza, mais plenamente, a noção de estrutura: ela fundamenta as relações e apresenta as informações que validam seu uso.

\subsection{Taxonomias}

Para a ENCYCLOPEDIA OF LIBRARY AND INFORMATION SCIENCE (1997, p.17) "uma taxonomia é um método para determinar classes de coisas reais através do estabelecimento de graus de semelhanças e diferenças".

A taxonomia (ou taxionomia, ou ainda taxinomia) vem de tax(i)(o) que significa arranjo, classificação, ordenação, mais nom(o)(ia), dar nomes, e pode ser traduzida como 
ciência da classificação. A taxonomia mais conhecida é "Classificação Geral do Seres Vivos", criada em 1735 pelo cientista sueco Karl von Linné (MELO, 1967, p.57).

Em 1958, o psicopedagogo americano Benjamin BLOOM elaborou um esquema de organização dos objetivos educacionais, com o objetivo de facilitar a comunicação entre os pesquisadores que se encontravam nos congressos da área de educação. Para ele:

\begin{abstract}
"Uma taxonomia dever ser construída de forma que a ordem dos termos corresponda a certa ordem real entre os fenômenos representados por estes termos. (...) A validade de uma taxonomia depende da demonstração de sua compatibilidade com conclusões resultantes de dados de pesquisa no campo que busca ordenar (...) Precisamos de um método para ordenar os fenômenos que permita o esclarecimento das propriedades essenciais e das inter-relações dos próprios fenômenos" (BLOOM e outros, 1974, p.15).
\end{abstract}

O termo taxonomia tem sido utilizado com freqüência cada vez maior, normalmente acompanhada do termo ontologia, e relacionado a assuntos como recuperação de informação, indexação, busca e navegação, intranets e portais, e também, gestão do conhecimento (GILCHRIST, 2003, p.8).

Da observação da prática de trabalho em empresa de consultoria na área de gestão do conhecimento, pode-se perceber a estreita relação (e às vezes, confusão) entre o que se chama no mercado de taxonomia e as Linguagens Documentárias, especialmente o tesauro. GARSHOL (2004, p.381) afirma que "o termo taxonomia tem sido amplamente usado e abusado a ponto de quando se refere a algo como taxonomia, esse algo pode ser qualquer coisa, apesar de que normalmente vai significar algum tipo de estrutura abstrata". 
Esse fato é confirmado por GILCHRIST (2003), quando afirma que as taxonomias atuais surgem como algo que pretende substituir os tesauros para a organização da informação. Para GILCHRIST (2003, p.10-1), os principais motivos que levaram a esse questionamento dos tesauros foram:

- A sobrecarga de informação espalhada nas redes eletrônicas e em massas documentais acumuladas;

- A alfabetização em informação, que se relaciona ao despreparo de muitos usuários para a busca de informação;

- A terminologia das organizações, que não aparecia representada nos seus tesauros e classificações de informação da própria empresa;

- A desestruturação das organizações, momento em que empresas com linguagens diferentes agrupam-se ou dividem-se, gerando problemas na recuperação da informação.

A partir disso, propõe que a taxonomia seja considerada uma classificação facetada, elaborada na forma de tesauro, com ênfase no relacionamento entre os termos, redes de sinônimos e esquemas gráficos de apresentação. No entanto, a taxonomia é menos completa que o tesauro, como podemos ver em GARSHOL (2004, p.382): "tesauros basicamente tomam as taxonomias (...) e as ampliam para torná-las mais capazes de descrever o mundo não apenas ao permitir que os assuntos sejam organizados em uma hierarquia, mas também ao permitir que outras afirmações sejam feitas sobre os assuntos". Estas são possíveis a partir da tipologia de relações que o tesauro aplica: termo específico, termo genérico, usado para, use, termo relacionado, e notas de escopo. 
GILCHRIST aponta pelo menos cinco tipos de taxonomia, caracterizadas em pesquisa realizada por ele e $\operatorname{KIBBY}(2000)^{23}$, na qual se reconheceu que a taxonomia é "um termo genérico e cobre várias técnicas e aplicações" (2003, p.11-3). Os tipos levantados são:

1. Diretórios para web. Como na página Yahoo!Brasil ${ }^{24}$, um menu de termos gerais é oferecido ao usuário, que pode navegá-lo por diversos níveis, chegando a informações, referências ou à possibilidade de usar o último termo clicado em motores de busca. Aqui, não há necessidade de hierarquias entre os níveis.

2. Taxonomias para indexação automática. Menu de dois níveis, com a taxonomia invisível ao usuário. Nela cada termo "carrega um algoritmo que contém listas de palavras e frases, sinônimos e variações sintáticas, pesos e instruções", que permite a extração automática de termos das informações. São utilizadas quando a massa de informação acumulada é tão grande que inviabiliza o trabalho manual. Aqui, "classificação e a taxonomia são construídas manualmente, e a taxonomia deve ser encarada como um tesauro enriquecido".

3. Taxonomias geradas por categorização automática. Programas que se dispõem a analisar automaticamente textos, baseados na análise estatística de ocorrência e co-ocorrência de termos. Dessa análise, são geradas categorias

\footnotetext{
${ }^{23}$ GILCHRIST, A.; KIBBY, P. Taxonomies for Business: Access and Connectivity in a Wired World. London: TFPL, 2000.

${ }^{24}$ http://www.yahoo.com.br [Acesso em: 10.12.2004].
} 
que classificam os documentos, também automaticamente. Os produtos são diretórios e/ou mapas gráficos bidimensionais.

4. Filtros de entrada. "A taxonomia é criada ou importada e utilizada para a formulação de perguntas", e procura-se reduzir as ambigüidades e proporcionar a busca via navegação pelas hierarquias. "Esta taxonomia é um tesauro formatado para permitir navegação fácil”.

5. Taxonomias corporativas. Trazem um pouco de cada elemento citado anteriormente. Podem ser encaradas como um híbrido de tesauro e ontologia, são feitas manualmente e geram um mapa capaz de guiar funcionários pelo conhecimento da organização. Funcionam como um megatesauro, com vários tesauros oriundos de áreas diversas relacionados, e podem trazem informações sobre a empresa, seus colaboradores, e sobre seu conteúdo. Auxiliam motores de busca e oferecem modelos de indexação. Podem ser vistas "como um esquema mestre, de onde uma série de ferramentas, como um tesauro, pode ser derivada".

Em relação à noção de estrutura, pode-se afirmar que, apesar deste instrumento apresentar algumas relações, por ser uma estrutura rígida, não permite que se absorvam as alterações que a dinâmica do campo de conhecimento e de seus usuários traz no seu uso. Dessa forma, em pouco tempo sua função comunicativa fica prejudicada, deixando de apresentar-se como um sistema de significação que faça sentido à comunidade que atende.

\subsection{Ontologias}

A palavra ontologia vem do grego, onde ontos significa ser ou existência e logos significa dar sentido, dar razão. 
Para GRUBER ${ }^{25}$ (citado por GILCHRIST, 2003, p.13), "uma ontologia pode ser definida como especificação explícita, formal de uma conceitualização compartilhada".

De acordo com KENT (2003, p.189), “ontologia é um ramo da metafísica que se preocupa com a natureza e as relações dos seres e a estrutura categórica da realidade". Estas são o objeto de estudo fundamental das ontologias. Ainda de acordo com o autor (p.190):

"O uso de ontologias para a organização de conhecimento é tanto antigo como novo. Aristóteles efetivamente usava idéias ontológicas no seu estudo da predicação e no seu sistema de classificação (suas categorias). No passado mais recente, Ranganathan utilizou princípios de organização de dinâmica ontológica (agora entendidos como idéia de organização de conhecimento conceito e relacional) no desenvolvimento do seu sistema de classificação facetada (a Colon Classification) para a organização de grandes bibliotecas acadêmicas".

As ontologias têm sido promovidas para aplicativos de tradução automática, modelagem empresarial, reuso de conhecimento e recuperação da informação, principalmente nas áreas de gestão do conhecimento e websemântica. Nesse contexto, BENJAMINS e outros ${ }^{26}$ (citados por GILCHRIST, 2003, p.15) citam três tipos de ontologias:

- Organizacional, que descreve a estrutura e o formato das informações.

- De Domínio, que descreve o conteúdo da fonte de informação.

${ }^{25}$ GRUBER, T. What is an ontology? Standford, s.d. Disponível em: http://www$\mathrm{ksl}$.Stanford.edu/kst/what-is-an-ontology.html

${ }^{26}$ BENJAMINS, V.R. et al. (KA)2: building ontologies for the Internet: a mid term report. International Journal of Human- Computer Sudies, v.51, n.3, sept. 1999, p.687-712. 
- Empresarial, que descreve e modela as necessidades de informação para os processos de negócio.

BERNERS-LEE, HENDLER e LASSILA ${ }^{27}$ (2004, citados por GILCHRIST, 2003, p.14) afirmam que "O tipo de ontologia mais comum para a web tem uma taxonomia e um grupo de regras de inferência".

MUSTAFA-ELHADI (2003, p.136) também comenta as características das ontologias:

"As ontologias emergiram como um dos meios mais populares para modelar o conhecimento de um domínio. Elas podem funcionar como um índice da memória de uma organização e facilitar as buscas semânticas e a recuperação do conhecimento da memória corporativa uma vez que são incorporadas em documentos e outros arquivos (...) Ontologias podem ser vistas como tesauros enriquecidos desde que incluam definições e relações semânticas. Seu papel é reduzir ambigüidades conceituais e terminológicas por meio da identificação e particularmente da definição de um grupo de conceitos relevantes que caracterizam um domínio".

No entanto, o que se observa na literatura da Ciência da Informação é ainda confuso. As características defendidas para as ontologias são muito similares às dos tesauros. O ganho pode estar na exploração de outras classes sintáticas de termos como verbos, advérbios, ao invés de somente o uso de substantivos. Entretanto, isto já foi proposto aos tesauros em 1998 por GARCÍA GUTIÉRREZ, como veremos a seguir.

De qualquer modo, é possível afirmar que a ontologia realiza mais a noção de estrutura e o processo de estruturação do que os instrumentos anteriores, pois integra

${ }^{27}$ BERNERS-LEE, T., HENDLER, J.; LASSILA, O. The SemanticWeb. 2001. Disponível em: http://www.sciam.com/article.cfm?articlelD=00048144-10D2-1C7084A9809EC588EF21\&catID=2 
maior número de características da linguagem natural, não se restringindo ao substantivo.

\subsection{Topic Maps}

De acordo com GARSHOL (2004, p.384-385) "A origem dos topic maps está no trabalho sobre a fusão de índices eletrônicos apresentando, portanto, uma técnica de classificação baseada em assunto. De fato, topic maps são organizados ao redor de tópicos, e cada tópico é usado para representar alguma coisa do mundo real". Nestes instrumentos, os tópicos representam conceitos, que são chamados de assuntos que, de acordo com a norma (norma ISO/IEC 13250) para topic maps, podem ser "qualquer coisa" (idem).

Para MOREIRO GONZÁLEZ e outros (2004, p.12) "Os topic maps propõem-se a modelar redes semânticas". PEPPER (2000, p.19) afirma que os topic maps surgiram como uma forma de representar as estruturas de conhecimento inerentes à tradição dos índices de livro, a fim de resolver os problemas de gestão da informação envolvidos na criação, manutenção e processamento de índices para documentação complexa. Com a evolução do modelo, seu escopo foi ampliado para abranger outros tipos de auxílio para navegação, como glossários, tesauros e referências cruzadas.

De acordo com MOREIRO GONZÁLEZ e outros (2004, p.3), a finalidade "dos topic maps consiste em proporcionar acesso à informação existente em diferentes redes semânticas, como podem ser os próprios tesauros".

Para GARSHOL (2004, p.390), o uso dos topic maps para representar metadados e classificação baseada em assunto possibilita a reutilização de classificações existentes e técnicas de classificação. 
A diferença dos instrumentos anteriores, um topic map conjuga redes relacionais e os próprios documentos relacionados aos termos que compõem essa rede. Agregam mais instrumentos de relação de natureza sintática, o que permite dizer que, como as ontologias, são tesauros enriquecidos.

\subsection{Mapas Conceituais}

De acordo com MOREIRO GONZÁLEZ e outros, "os mapas conceituais são uma técnica para representar o conhecimento em gráficos". O conhecimento é apresentado através de redes de conceitos, compostas por nós e links, que representam, respectivamente, conceitos e as relações entre os conceitos (2004, p.2).

O mapa conceitual utiliza-se de diagramas para complementar a função comunicativa do conhecimento mediante diferentes linguagens visuais para representar os conceitos e as relações entre eles. É uma ferramenta útil para a organização de nova informação e para sua integração ao conhecimento existente (MOREIRO GONZÁLEZ e outros, 2004, p.3).

Em geral, os mapas conceituais são usados para infometrias, desde que a indexação por detrás desse instrumento seja confiável. Por permitir a apresentação de maior número de ligações entre os termos constantes em seus nós, se aproximam mais das noções de estrutura e de estruturação.

\subsection{A Linguagem Epistemográfica de GARCÍA GUTIÉRREZ}

GARCÍA GUTIÉRREZ, em 1998, lançou um trabalho com o objetivo de desenvolver uma metodologia de construção de uma linguagem associativa peculiar a partir do Tesauro de Patrimônio Histórico Andaluz - TPHA - "de modo que cada proposição, as 
categorias léxicas do vocabulário, as categorias da estrutura, as regras e macroregras também fossem verificadas em um universo de referência real” (1998, p.7).

Insatisfeito com os resultados obtidos até então com uso de tesauros e com a aplicação da norma ISO 2788, de 1986, "Diretrizes para o estabelecimento e desenvolvimento de tesauros monolíngües", GARCÍA GUTIÉRREZ pensou em novas ferramentas lógico-semânticas baseadas em novas hipóteses de trabalho. Resumidamente, a idéia consiste em uma Linguagem Documentária substituta do tesauro, mas que o utilize como referência teórica e empírica para sua elaboração. As novas linguagens potencializariam o nível sintagmático ao preço de modificações nos componentes lexicais, nos operadores e nas regras de representação e recuperação, e simulariam enunciados, atuando como representações pragmáticas de mapas cognitivos. Em sua proposta, o mais interessante é perda do papel dominante da hierarquia e a valorização das relações horizontais (KOBASHI, 2000, p.132-133).

Essa nova linguagem foi chamada de linguagem epistemográfica, onde "linguagem significa sistema sígnico sujeito a convenções estruturais, funcionais e pragmáticas" e “epistemografia supõe a representação formalizada, em uma base de conhecimento com fins documentários (de recuperação de informação), de um construto cognitivo" (GARCÍA GUTIÉRREZ, 1998, p.15).

Ao usar uma linguagem associativa, o autor destaca as estruturas de organização horizontais da linguagem e, dessa forma, atribui menor importância à estrutura hierárquica ou vertical. Entretanto, "superar a arborização como procedimento não supõe negar-la como relação" (GARCÍA GUTIÉRREZ, 1998, p.34), lembra o autor.

Dessa forma, ganha força o TR, termo relacionado, mas não do modo como vem sido usado nos tesauros tradicionais. De acordo com GARCÍA GUTIÉRREZ (1998, p.32), 
"o operador de associação - TR - dos tesauros convencionais se inclina ao eixo paradigmático alijando-se, e alijando os tesauros, de seus fins teóricos. Quando um usuário localiza /cinematografia/ e, mediante TR, se remete a /cinemas/ ou /filmes/, normalmente um descritor pelo outro, não os conserva no nível enunciativo, requisito que dá cumprimento à função sintagmática"

O autor sugere que termos relacionados podem ocorrer sob dois tipos: o primeiro, como relação intercategorial associativa ou atributiva, e o segundo, como relação intracategoria coordenativa (idem, p.37). A relação associativa ou atributiva seria aquela que adjetiva um conceito ou esclarece alguma de suas propriedades, quando da união dos descritores envolvidos na relação. A relação coordenativa representaria a união de conceitos que formariam um outro, mas sem adjetivação ou descrição de propriedades.

GARCÍA GUTIÉRREZ, já em 1990, afirmava que "a construção de uma estrutura gramatical [eixo sintagmático, por exemplo] em uma $\mathrm{Id}^{28}$ é tão importante como a existência da própria Id e uma justificativa imprescindível para a conservação da mesma denominação “ (GARCÍA GUTIÉRREZ, 1990, p.38).

Na proposta mais atual, GARCÍA GUTIÉRREZ (1998, p.26-27) propõe o uso, além dos substantivos e expressões nominais, de:

- Adjetivos: como descritores qualificadores da linguagem, em espera de construção de um enunciado (mediante união morfológica) por parte do usuário antes de acessar o sistema de informação;

${ }^{28}$ GARCÍA GUTIÉRREZ emprega "Id" para abreviar Linguagem Documentária, ao invés de "LD", como os demais autores pesquisados. Para GARCÍA GUTIÉRREZ, "LD" refere-se á Lingüística Documentaría. 
- Verbos: gerúndios para expressar ações e particípios para expressar estados;

- Prefixos: formantes de termo, que deveriam ser listados separadamente e chamados se necessário;

- Advérbios: modo, lugar, tempo;

- Nomes próprios.

O autor somente não considera as preposições e os artigos que, de acordo com LAMÍQUIZ ${ }^{29}$ (1974, citado por GARCÍA GUTIÉRREZ, 1990, p.257), são isentos de significação própria.

GARCÍA GUTIÉRREZ afirma que as Linguagens Documentárias "não potenciam a gestão de suas bases léxicas mediante operadores booleanos ou outras gramáticas mais complexas, nem desenvolvem satisfatoriamente o eixo sintagmático de seus universos cognitivos, insuficiência que as alija do lingüístico" e ignoram o comportamento enunciativo da linguagem natural (GARCÍA GUTIÉRREZ, 1998, p.13).

O autor considera que "para conseguir um entorno "amigável" nas linguagens de representação, a transformação não só deve dar-se em termos de vocabulários mas também de estrutura e discurso" (GARCÍA GUTIÉRREZ, 1998, p.18).

De acordo com GARCÍA GUTIÉRREZ (1990, p.79), na construção de uma linguagem são as relações introduzidas que determinam sua estrutura, e conseqüentemente,

${ }^{29}$ LAMÍQUEZ, V. Lingüística española. 2.ed. Sevilla: Universidad de Sevilla, 1974. 
também sua significação. Por isso a crítica à estrutura hierárquica, que para o autor, nada mais é do que uma forma de descrição da linguagem. Para o autor,
"a estrutura explícita de uma ld deve fundamenta-se mais sobre indicadores sintagmáticos, com alguma exceção, e extralingüísticos. À maneira da língua, mas sem a vocação de inter-relacionar palavras, mas conceitos, as relações paradigmáticas das Id devem aparecer tacitamente e, em conseqüência, emanar da própria estrutura utilizando a menor quantidade possível de indicadores físicos" (GARCÍA GUTIÉRREZ, 1990, p.118).

GARCÍA GUTIÉRREZ defende o princípio da entropia, pelo qual propõe que nas Linguagens Documentárias existam mais significados do que significantes, ou seja, "deve-se tender à construção de todos os conteúdos possíveis a partir de uns poucos termos em combinação potencial” (GARCÍA GUTIÉRREZ, 1990, P.137). Para isso, é necessária a sintaxe, indicação de contexto, e facetas nas Linguagens Documentárias.

A vertente inaugurada por GARCÍA GUTIÉRREZ merece maior investigação. Ao destacar a função sintagmática, ressaltar a possibilidade de usar os TR não apenas como relação atributiva ou adjetiva, mas coordenativa, GARCÍA GUTIÉRREZ reivindica, efetivamente, a sintagmatização. De fato, nos tesauros convencionais os TR tendem ao eixo paradigmático, à medida que se cristalizam no interior do instrumento e que não dão oportunidade efetiva à combinação.

A sintagmatização, mais do que a característica epistemográfica (que de qualquer modo se aproxima do uso das referências de uso proporcionadas pela Terminologia), é o aspecto que ressalta na aproximação desse instrumento à noção de estrutura e de estruturação. É ela que abre o tesauro às ocorrências. Mas sua viabilidade tem de ser ainda pesquisada. 


\section{Considerações finais}

Mesmo que retirada de um documento tratado "uma palavra usada ao acaso, sem obedecer a um rigor contextual, pode transformar a idéia original do autor do documento e produzir outra" (FUJITA, 1989, p.121).

É possível observar uma progressão de idéias ao longo das descrições feitas acima, como também, conforme lembra GILCHRIST (2003, p.15), uma sobreposição de detalhes e confusão em relação aos papéis de cada forma de organizar ou comunicar informações.

Em maior ou menor nível, todas as formas citadas lidam com a linguagem natural e preocupam-se com a circulação e compreensão da informação. Lidam, portanto, com a noção de estrutura, mas nem tanto com o processo de estruturação que permitiria renovar e reorganizar continuamente o instrumento de organização de informações e de indexação.

Pode-se perceber que, gradativamente, os distintos instrumentos se organizam para contemplar um maior número de características da linguagem em funcionamento. Não se pode afirmar, no entanto, que tenham êxito. Ao simular as características da linguagem natural, sempre estamos no circuito da artificialização. A incorporação de todas as características da linguagem significaria a própria negação das iniciativas. Ao final, voltaríamos à linguagem natural ?...

Trata-se, pois, de verificar, dada a necessidade de filtrar a informação como requisito para facilitar o acesso, a possibilidade de conjugar recursos: o tesauro documentário, o tesauro terminológico, as ontologias e suas formas de apresentação, os topic maps. Trata-se, também, de propor o aprofundamento dos estudos sobre o Tesauro 
Epistemográfico pela proposta que oferece de aumentar as possibilidades de sintagmatização. Ao menos teoricamente, tal proposta enuncia a possibilidade de incorporar os avanços da Lingüística Estrutural por meio da otimização dos processos de sintagmatização. Cada um dos instrumentos analisados tem seus pontos positivos e negativos. Uns lidam melhor com as bases que sustentam a interpretação dos elementos que os compõem. Outros, com a apresentação visual dos termos e de suas relações. Outros, ainda, permitem vincular representações e documentos.

Uns são mais apropriados à indexação; outros, à organização de informações em site; outros, ainda, exercem função pedagógica por meio da visualização das relações entre termos e de sua exemplificação.

Ao final desse trabalho, temos a sensação da necessidade de continuar os investimentos. Às soluções apresentadas e aperfeiçoadas ao longo do tempo, nem sempre na ordem cronológica, outras certamente se agregarão.

Resta dizer que, apesar das variações observadas entre os instrumentos, a noção de organização estrutural sempre está presente. A atualização das estruturas inicialmente colocadas - pela estruturação contínua - é que se apresenta como problema. 


\section{Referências}

ARCHIVES AUTHORITY OF NEW SOUTH WALES. The Keyword AAA: a thesaurus of general terms. Sydney, 1998.

BARANOW, U.G. Perspectivas na contribuição da Lingüística e de áreas afins à Ciência da Informação. Ciência da Informação, v.12, n.1, p.23-35, 1983.

BENVENISTE, E. 'Estrutura' em lingüística. In: Bastide, R. (org.) Usos e sentidos do termo "estrutura". São Paulo: Herder; Edusp, 1971, p.23-31.

BENVENISTE, É. Vista d'olhos sobre o desenvolvimento da lingüística. In: Problemas de lingüística geral I. Campinas: Pontes, 1991. P.19-33.

BLOOM, B.S.; ENGELHART, M.D.; FURST, E.J; HILL, W.H.; KRATHWOHL, D.R. Taxionomia de objetivos educacionais 1 - domínio cognitivo. Porto Alegre: Globo, 1974.

BOCCATO, V.R.C.; FUJITA, M.S.L. Avaliação da linguagem documentária DeCS na área de fonoaudiologia na perspectiva do usuário: estudo de observação da recuperação da informação com protocolo verbal. Encontros Bibli, Florianópolis, $\mathrm{n}$. 21, p.16-33, $1^{\circ}$ sem. 2006.

CABRÉ, M.T. Situación y aspectos generales de la terminología. In: — La terminología: representación y comunicación: elementos para una teoría de base comunicativa y otros artículos. Barcelona: IULA/Universitat Pompeu Fabra, 1999. p. 21-68.

CABRÉ, M.T. (1993). La terminología: teoría, metodologia, aplicaciones. Barcelona : Ed. Antártida; Empúries.

CACALY, S. (coord). Dictionnaire encyclopédique de l'information et de la documentation. Paris: Nathan, 1997.

CAVALCANTI, C.R. Indexação e tesauro: metodologia e técnicas. Brasília: Associação de Bibliotecários do Distrito Federal, 1978.

CHAUMIER, J. As técnicas documentais. Apartado 8, Portugal: Publicações Europa-América, 1974. trad. Jorge de Sampaio.

CINTRA, A.M.M. Elementos de lingüística para estudos de indexação. Ciência da Informação, v.12, n.1, p.5-22, 1983.

CINTRA A.M.M. et al. Do termo ao descritor. Revista de Comunicação \& Artes, São Paulo, v.17, n.28, p.75-82, jan./abr. 1994.

CINTRA, A.M.M. et al. La interface análisis documental, lingüística documental y terminologia. Cuadernos de Adab, Salamanca, v. 1, n. 2, p. 382-388, 1993. 
CINTRA, A.M.M. et al. Para entender as linguagens documentárias. 2ed. rev. e ampl. São Paulo: Polis, 2002.

COYAUD, M. Introduction a l'étude des langages documentaries. Paris: Librarie C. Klincksieck, 1966.

CROSS, R.C. et al. L'automatisarion des recherches documentaries. Paris: Gauthier-Villars, 1968. 2ed. revue et augmente.

CUNHA, I.M.R.F. Análise documentária. In. : SMIT, J.W. (coord.). Análise documentária : a análise da síntese. Brasília : IBICT, 1997. 2.ed. p.39-62

CUNHA, I.M.R.F. Do mito à análise documentária. São Paulo : Edusp, 1990. (Coleção Teses, 11).

CUNHA, I.M.R.F ; KOBASHI, N.Y. Análise documentária e inteligência artificial. Revista Brasileira de Biblioteconomia e Documentação, v.24, n.1/4, p.38-62, jan./dez. 1991.

DASCAL, M. As semiologias contemporâneas. In: La sémiologie de Leibniz. Paris : Aubier Montaigne, 1978. cap. 2 (Tradução para uso didático, M.L.G. LARA).

DODEBEI, V.L.D. Tesauro : linguagem de representação da meméria documentária. Niterói : Intertexto ; Rio de Janeiro : Interciência, 2002.

DOSSE, F. História do estruturalismo, v.1: o campo do signo, 1845-1966. São

Paulo: Ensaio; Campinas, SP: Editora da Universidade Estadual de Campinas, 1993.

DOSSE, F. História do estruturalismo, v.2: o canto do cisne, de 1967 aos nossos dias. São Paulo: Ensaio; Campinas, SP: Editora da Universidade Estadual de Campinas, 1994.

DUBUC, R. Qué es la terminología?: In: ——. Manual de terminología. Santiago de Chile: Unión Latina; Ril, 1999. P.19-30.

DUBUC, R. Qu'est-ce que la terminologie? Le Banque des Mots, Paris, n.13, p.3-14, 1977.

DUCROT, O. O dizer e o dito. Campinas, SP: Pontes, 1987.

DUCROT, O. TODOROV, T. Dicionário das ciências da linguagem. Lisboa : Dom Quixote, 1973.

DUCROT, O.; SCHAEFFER, J.M. Nouveau dictionnaire encyclopédique des sciences du language. Paris: Éditions du Seuil, 1995.

ECO, U. A estrutura ausente. São Paulo: Perspectiva, 1997. 7ed.

ENCYCLOPEDIA OF LIBRARY AND INFORMATION SCIENCE. New York: M. Deker, 1997. v.19, p.187. 
FUJITA, M.S.L. Avaliação da eficácia de recuperação do sistema de indexação PRECIS. Ciência da Informação, v.18, n.2, p.120-134, jul./dez. 1989.

FUJITA, M.S.L. A identificação de conceitos no processo de análise de assunto para indexação. Revista Digital de Biblioteconomia e Ciência da Informação, Campinas, v.1, n.1, p. 60-90, jul./dez. 2003.

FUJITA, M.S.L. Linguagem documentária em odontologia: uma aplicação do sistema de indexação PRECIS. São Paulo, 1992, 3v. (doutorado, ECA).

FUJITA, M.S.L. PRECIS: I - Precis: Perspectiva histórica e técnica do seu desenvolvimento e aplicação. Revista Brasileira de Biblioteconomia e Documentação, São Paulo, v.21, n.1/2, jan./jun. 1988.

GARCÍA GUTIÉRREZ, A. L. Estructura lingüística de la documentación: teoría y método. Murcia: Universidad, Secretariado de Publicaciones, 1990.

GARCÍA GUTIÉRREZ, A. L. Principios de lenguaje epistemográfica: la representación del conocimiento sobre Patrimonio Histórico Andaluz. Sevilla: Instituto Andaluz del Patrimonio Histórico, 1998.

GARCÍA GUTIÉRREZ, A. L. Procedimientos de análisis documental automático: estudo de caso. Sevilla: Instituto Andaluz del Patrimonio Histórico, 1996.

GARCÍA GUTIÉRREZ, A.; LUCAS FERNÁNDEZ, R. Documentación automatizada en los medios informativos. Madrid: Paraninfo, 1987.

GARDIN, J.C. Elemtents d' um modele pour la description des lexiques documentaires. Bulletin des Biblioteques de France, n.5, p.171-182.

GARDIN, J.C. Document analysis and linguistic theory. Journal of Documentation, v.29, n.2, p.137-68, June 1973.

GARSHOL, L.M. Metadata? Thesauri? Taxonomies? Topic Maps! Making sense of it all. Journal of Information Science, v.30, n.4, p.378-391, 2004.

GILCHRIST, A. Thesauri, taxonomies, and ontologies - an etymological note. Journal of Documentation, v.59, n. 1, p.7-18, 2003.

GOMES, H.E. (coord.) Manual de elaboração de tesauros monolíngües. Brasília: Programa Nacional de Bibliotecas de Instituições de Ensino Superior, 1990.

GRANGER, G.G. Filosofia do estilo. São Paulo: Perspectiva; Edusp, 1974.

GREEN, R. Syntagmatic Relationships in Index Languages: A Reassessment. Library Quarterly, v.65, n.4, Oct. 1995, p.365-85.

GREIMAS, A.J.; COURTÉS, J. Dicionário de Semiótica. São Paulo: Cultrix, 1979.

GREIMAS, A.J. Semântica estrutural. São Paulo: Cultrix; Edusp, 1976. 
GUIMARÃES, J.A.C. Análise documentária em jurisprudência: subsídios para uma metodologia de indexação de códigos trabalhistas brasileiros. São Paulo, ECA, 1994 (doutorado).

GUIMARÃES, J.A.C. A recuperação temática da informação em direito do trabalho no Brasil: propostas para uma linguagem de indexação na área. São Paulo, ECA, 1988 (mestrado).

HARLAND, Richard. Superstructuralism: the philosophy of structuralism and post structuralism. London: Methuen, 1987.

HUTCHINS, W.J. languages of indexing and classification. Herts: Peter Peregrinus, 1975.

ISO 1087-1. Terminology work - Vocabulary, Part 1: theory and application/Travaux terminologiques - Vocabulaire - Partie 1: théorie and application. Genève : International Standard Organization, 2000.

ISO 704. Terminology work - principles and methods. 2nd ed. Genève : International Standard Organization, 2000.

KENT, R.E. The IFF foundation for ontological knowledge organization. Cataloguing \& Classification Quarterly, v.37, n.1/2, p.187-203, 2003.

KOBASHI, N.Y. Análise documentária: considerações sobre um modelo lógicosemântico. In. CUNHA, I.M.R.F (coord.). Análise documentária: considerações teóricas e experimentações. São Paulo: FEBAB, 1989.

KOBASHI, N.Y. Análise documentária: metodologias para indexação e resumo. 1995 (Apostila).

KOBASHI, N.Y. Resenhas e Resumos - I Tema: Tesauros: Principios de lenguaje epistemográfico: la representación del conocimiento sobre Patrimonio Histórico Andaluz, Antonio García Gutiérrez. Revista Brasileira de Biblioteconomia e Documentação, São Paulo, nova série, v.1, n.2, p.132-134, 2000.

LARA, M.G.L. Dos sistemas de classificação bibliográfica às search engines (I). São Paulo: APB, 2001a. (Ensaios APB, 90).

LARA, M.G.L. Dos sistemas de classificação bibliográfica às search engines (II). São Paulo: APB, 2001b. (Ensaios APB, 91).

LARA, M.L.G. Linguagens documentárias, instrumentos de mediação e comunicação. Revista Brasileira de Biblioteconomia e Documentação, v.26, n.1/2, p.72-80, jan./jun. 1993.

LARA (a), M.L.G. O processo de construção da informação documentária e o processo de conhecimento. Perspectivas em Ciência da Informação, Belo Horizonte, v.7, n.2, p.127-139, jul./dez. 2002 
LARA (b), M.L.G. Representação documentária: em jogo a significação. São Paulo, 1993. (dissertação - mestrado).

LARA, M.L.G. Representação e linguagens documentárias: bases teóricometodológicas. São Paulo, 1999. (tese-doutorado).

LARA, M. L. G. Terminologia (e terminologias) e documentação. In: VII SIMPÓSIO IBERO-AMERICANO DE TERMINOLOGIA, 2000, Lisboa. Terminologia e indústrias da língua. Lisboa: ILTEC, 2003.

LARA, M.L.G. A terminologia como instrumento para construção de ferramentas semânticas. Anais do XX CBBD - Congresso Brasileiro de Biblioteconomia e Ciência da Informação, Fortaleza, jun. 2002. (publicação em cd-rom).

LARA, M.L.G.; TÁLAMO, M.F.G.M. . Lingüística documentária e terminologia: experiência didática na interface das disciplinas. In: VII Encontro Nacional de Pesquisa em Ciência da Informação, 2006, Marília. A dimensão epistemológica da Ciência da Informação e suas interfaces teóricas, políticas e institucionais nos processos de produção, acesso e disseminação da informação. Marília: UNESP; ANCIB, 2006.

LEAL, J.J. Terminologia na indústria. Terminômetro, n. especial - A Terminologia no Brasil, p.31-2, 1998.

LE GUERN, M. Sur les relations entre terminologie et lexique. Meta, v.34, n.3, p.34043, 1989.

LEPARGNEUR, H. Introdução aos estruturalismos. São Paulo: Herder, 1972.

LOPES, E. A identidade e a diferença. São Paulo: EDUSP, 1997.

LOPES, E. Fundamentos da lingüística contemporânea. São Paulo: Cultrix, 1987.

MELO, J.M. Ciências da Informação: classificação e conceitos. São Paulo: Centro de Pesquisa da Comunicação Social, 1967.

MOREIRO GONZÁLEZ, J. et al. De los tesauros a los topic maps: nuevo estándar para la representación y la organización de la información. Encontros Bibli: Revista Eletrônica de Biblioteconomia e Ciência da Informação, Florianópolis, n.18, $2^{\circ}$ sem. 2004.

MUSTAFA-ELHADI, W. Human language technology and its role in information access and management. Cataloguing \& Classification Quarterly, v.37, n.1/2, p.131-51, 2003.

NATIONAL ARCHIVES OF AUSTRALIA. Developing a function thesaurus: guidelines for Commonwealth Agencies. Canberra, 2000.

NAVARRO, S. Interface entre lingüística e indexação: revisão de literatura. Revista Brasileira de Biblioteconomia e Documentação, v.21, n.1/2, p.46-62, jan./jun. 1988. 
ORLANDI, E.P. O que é lingüística. São Paulo: Brasiliense, 2003. (Primeiros Passos, 184)

PAVEAU, M.A.; SARFATI, G.E. As grandes teorias da lingüística: da gramática comparada à pragmática. São Carlos: Claraluz, 2006.

PEPPER, S. The TAO of Topic Maps, 2000. Disponível em:

www.ontopia.net/topicmaps/materials/tao.html (Acesso em: 19.04.2004].

PETERS, Michel. Estruturalismo e pós-estruturalismo. Rubedo - Revista de Literatura. <http: //www.rubedo.psc.br/Artlivro/estpost.htm> Acesso em 12.12.2006. Originalmente publicado em: PETERS, M. Pós-estruturalismo e filosofia da diferença. Belo Horizonte: Autêntica Editora, 2000. (cap.3).

RADFORD, Gary P.; RADFORD, Marie L. Structuralism, post-structuralism, and the library: de Saussure and Foucault. Journal of Documentation, v.61, n.1, 2005, p.6078.

SAGER, J.C. A practical course in terminology processing. Amesterdam; Philadelphia: John Benjamins, 1990. (p.13-54).

SAGER, J.C. Prólogo: la terminología, puente entre varios mundos. In: CABRÉ, M.T. La terminología: teoría, metodología, aplicaciones. Barcelona: Antártica; Empúries, 1993. p.11-7.

SILVA, M.R.; FUJITA, M.S.L. A prática de indexação: análise da evolução de tendências teóricas e metodológicas. Transinformação, Campinas, v.16, n.2, p.133161, maio/ago., 2004.

SMIT, J.W; KOBASHI, N.Y. Como construir vocabulários controlados para aplicação em arquivos. São Paulo: Associação de Arquivistas de São Paulo, 2001. (Projeto Como Fazer)

TÁLAMO, M.F.G.M. Linguagem documentária. São Paulo: APB, 1997. (Ensaios APB, n. 45).

TÁLAMO, M.F.G.M. Terminologia e documentação. TradTerm, São Paulo, n.7, 2001, p.141-151.

TÁLAMO, M.F.G.M. et al. Contribuição da terminologia para a elaboração de tesauros. Ciência da Informação, Brasília, v.21, n.3, p.197-200, 1992.

TÁLAMO, M.F.G.M; LARA, M.L.G. O campo da lingüística documentária. TransInformação, Campinas, v.18, n.3, p.203-211, set./dez. 2006.

VALE, E.A. Linguagens de indexação. In. : SMIT, J.W. (coord.). Análise documentária : a análise da síntese. Brasília : IBICT, 1997. 2.ed. p.13-28. 
VALIO, E.B.M.; OLIVEIRA, V.F.F. Terminologia da ciência da informação: abordagem da análise do discurso. Perspectivas em Ciência da Informação, Belo Horizonte, v.8, n.2, jul./dez. 2003.

YOUNG, H. (ed.) Glosario ALA de Bibliotecología y Ciencias de la Información. Madrid: Díaz de Santos, 1988.

ZAVITOSKI, M.T. Exploração do uso do tesauro como instrumento de recuperação da informação. São Paulo, 2001. Dissertação (Mestrado) -Escola de Comunicações e Artes. Universidade de São Paulo. 